\author{
UNIVERSIDADE DE SÃO PAULO \\ FACULDADE DE FILOSOFIA, LETRAS E CIÊNCIAS HUMANAS \\ DEPARTAMENTO DE LETRAS CLÁSSICAS E VERNÁCULAS \\ PROGRAMA DE PÓS-GRADUAÇÃO EM LITERATURA PORTUGUESA
}

CAROLINE DE ALMEIDA NASCIMENTO

Uma leitura intertextual da História e da Literatura Portuguesas

por Helder Costa

São Paulo

2015 


\author{
UNIVERSIDADE DE SÃO PAULO \\ FACULDADE DE FILOSOFIA, LETRAS E CIÊNCIAS HUMANAS \\ DEPARTAMENTO DE LETRAS CLÁSSICAS E VERNÁCULAS \\ PROGRAMA DE PÓS-GRADUAÇÃO EM LITERATURA PORTUGUESA
}

\title{
Uma leitura intertextual da História e da Literatura Portuguesas por Helder Costa
}

Caroline de Almeida Nascimento

Dissertação apresentada ao

Programa de Pós-Graduação em Literatura Portuguesa do

Departamento de Letras Clássicas e Vernáculas da

Faculdade de Filosofia, Letras e Ciências Humanas da Universidade de São Paulo, para a obtenção do título de Mestre em Literatura Portuguesa.

Orientador: Prof. ${ }^{a}$ Dra. Flavia Maria Ferraz Sampaio Corradin

Versão Corrigida

São Paulo

2015 
Dedico este trabalho a meus pais, Luzia e José Carlos, que tanto se esforçaram e me estimularam para que eu pudesse chegar até aqui; à tia Terezinha e irmã Cris, que sempre foram parceiras importantes nesta empreitada; a André, companheiro de todas as horas e leitor crítico; aos colegas da pós-graduação, que contribuíram significativamente para que eu pudesse ampliar meus horizontes durante as pesquisas; ao Prof. Dr. Francisco Maciel Silveira, por quem nutro muita admiração, e, com especial carinho, à minha orientadora, Prof. Dra. Flavia Maria Corradin, cujo incentivo, dedicação e compreensão foram fundamentais para que esta dissertação fosse possível. 


\section{RESUMO}

O presente estudo consiste na análise e na interpretação crítica do texto teatral A Viagem - Camões

- Poeta prático, de autoria do encenador e dramaturgo português Helder Costa, sob a óptica do emprego de recursos intertextuais como a paródia, a paráfrase e a estilização, que compõem o tecido textual, que traz à baila episódios da história lusitana, trajados em novas roupagens, distintas, sob diversos aspectos, daquelas que predominam no imaginário coletivo luso. A partir da visão brechtiana de teatro, de que a função social dessa arte reside, em grande medida, em despertar a consciência popular para a situação do presente por meio da reflexão sobre o passado, o texto teatral, objeto da presente pesquisa, estabelece diálogo entre o pretérito áureo das expansões marítimas e o contexto de escrita da peça, logo após o término da ditadura salazarista.

Outro enfoque desse trabalho é o "atrito" gerado a partir do emprego da metaficção historiográfica no preenchimento das lacunas deixadas pelos incontestáveis "fatos históricos" (mote para a escrita da peça teatral de Helder Costa), que são "ficcionalizados" de modo a evidenciar questões acerca da arbitrariedade das fronteiras entre Literatura e História. Observa-se, ora no plano macro, ora no plano micro, que a peça de Helder Costa configura-se como uma proposta de revisão da essência saudosista do ser português.

Palavras-chave: Camões. Teatro. Helder Costa. Brecht. Intertextualidade. História. 


\begin{abstract}
This study consists in the analysis and the critical interpretation of the theatrical text A Viagem Camões - Poeta prático (The Journey - Camões - Practical poet), written by the Portuguese director and playwright Helder Costa, from the perspective of the employment of intertextual features such as parody, paraphrase and styling, which compose the textual content, which narrates episodes of the Portuguese history, "repackaged", different in several respects from those that predominate in the Portuguese collective imagination. Based on the perspective of the Brechtian theater, that the social function of this art largely lies in the awakening of the popular awareness of the present through a reflection about the past, the theatrical text, object of this research, establishes a dialogue between the golden past of the maritime expansions and the context of the period in which the play was written, soon after the end of Salazar's dictatorship.

Another focus of this work is the "friction" generated from the use of historiographical metafiction in filling the gaps left by the incontrovertible "historical facts" (a motto for the writing of Helder Costa's play), which are "fictionalized" in order to highlight questions regarding the arbitrariness of the borders between Literature and History. It can be observed, both in the macro and in the micro plan, that Helder Costa's play is configured as a proposal to revise the nostalgic essence of the Portuguese being.
\end{abstract}

Keywords: Camões. Theater. Helder Costa. Brecht. Intertextuality. History. 


\section{SUMÁRIO}

\section{TEMPO E ESPAÇO DA HISTÓRIA NO TEATRO ..................... 6}

Arte e teatro no despontar dos tempos................................................. 7

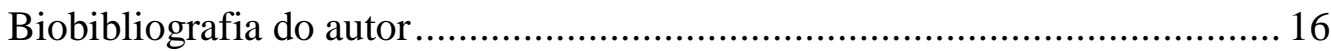

Justificativa da escolha da peça............................................................ 22

1 ENREDO E PERSONAGENS................................................ 26

1.1 Um reino em formação ................................................................... 26

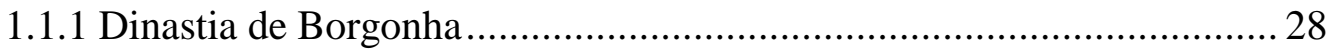

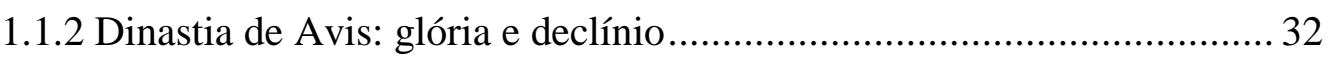

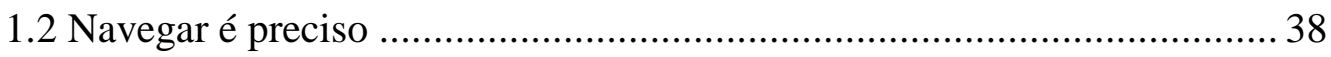

1.3 Novas concepções estéticas e filosóficas .............................................. 43

1.4 Camões: o homem ignoto por trás do gênio poético .............................. 49

1.5 Diogo do Couto: cronista crítico de seu tempo ...................................... 53

1.6 Considerações gerais acerca do capítulo ...............................................55

2 ABREM-SE AS CORTINAS ................................................57

2.1 Cena I - Ato I - Camões apresenta El-Rei Seleuco .................................. 61

2.2 Cena II - Ato I - O Mal-Cozinhado ...................................................... 69

2.3 Cena III - Ato I - Camões pede protecção a D. Violante ......................... 75

2.4 Cena IV - Ato I - Na prisão do Tronco .................................................. 78

2.5 Cena V - Ato I - Portugal e a expansão ............................................... 82

2.6 Cena VI - Ato I - Enchem-se as caravelas .............................................. 86

3 A VIAGEM E SEUS DESDOBRAMENTOS ............................. 91

3.1 Cena VII - Ato I - A Viagem ..................................................... 91

3.2 Cena I - Ato II - Espalhar a Fé e o Império ............................................ 100

3.3 Cena II - Ato II - Camões na Índia ..................................................... 104

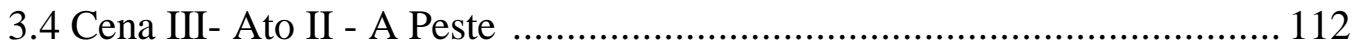

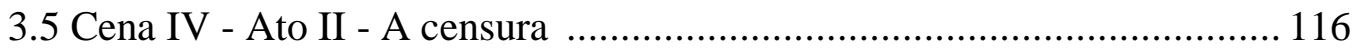

3.6 Cena V - Ato II - A Nova Ordem ....................................................... 119

4 DESENLACE DA JORNADA.................................................. 126

CONSIDERAÇÕES FINAIS................................................. 137

REFERÊNCIAS ................................................................................. 140

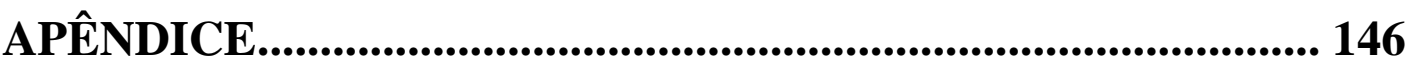




\title{
TEMPO E ESPAÇO DA HISTÓRIA NO TEATRO
}

\begin{abstract}
O teatro tem uma história específica, capítulo essencial da história da produção cultural da humanidade. Nessa trajetória, o que mais tem sido modificado é o próprio significado da atividade teatral: sua função social. [O espaço de representação teatral] (...) estabelece, em nível de razão e emoção, uma reflexão e um diálogo vivo e revelador com a plateia, ou seja, qual for o espaço dos espectadores. [O teatro] Incapaz de agir diretamente no processo de transformação social, age diretamente sobre os homens, que são os verdadeiros agentes da construção da vida social.

PEIXOTO, 2012.
\end{abstract}

De acordo com Fernando Peixoto em $O$ que é teatro? (2012), a arte cênica assumiu diversas formas, de acordo com a função social que desempenhou ao longo da História, modificando, deste modo, seu próprio significado. Em seguida, o autor atribui ao teatro a incapacidade de agir na esfera social de maneira direta, dirigindo-se então aos agentes sociais, que poderiam, de fato, transformar o presente. Tal visão remete à proposta didático/épica de Bertold Brecht, de que: “o espectador deveria ser transformado, de um observador saboreante num parceiro especulativo."1 (BERTHOLD, 2010, p. 510).

Sob a óptica do teatro como fonte de reflexão para o homem modificar seu presente, o texto teatral A Viagem - Camões - Poeta prático, de Helder Costa, publicado em 1979, destaca-se como a aplicação da proposta de Brecht no contexto de Portugal moderno, pós Revolução dos Cravos, ocorrida em 1974, episódio que marcou o fim da ditadura salazarista de quarenta e oito anos no país. Esse texto teatral visa a impelir a mudança no presente, visto que elege o teatro épico, em sentido brechtiano, como ferramenta para tal intento. Valendo-se de recursos intertextuais, tais como a paráfrase, a estilização e a paródia, além da mescla entre História e Literatura, o dramaturgo e encenador Helder Costa reescreve criticamente o chamado período áureo português, situado entre os séculos XIV a XVI.

O presente trabalho tem por objetivo analisar a relação que o dramaturgo tece entre o passado áureo português, relido por meio da utilização de recursos intertextuais e a mescla de ficção/história, e o tempo presente, quando a peça é escrita, 1979.

A fim de traçar um percurso analítico que abarque tanto a construção da peça, no que tange aos diálogos intertextuais, quanto literários e históricos, e à relação que o autor estabelece entre a releitura do passado e o tempo presente como finalidade de sua escrita, organizam-se os capítulos a seguir. No capítulo introdutório, traça-se uma breve visão da arte como expressão humana e o desenvolvimento do teatro como uma dessas formas de representar o mundo, seguido da

\footnotetext{
${ }^{1}$ As citações utilizadas na dissertação serão mantidas em sua ortografia original.
} 
biobibliografia de Helder Costa, visto que este autor não é muito conhecido no Brasil, e a justificativa da escolha do texto teatral. No capítulo seguinte, expõe-se a História de Portugal, desde sua formação como reino independente, condição fundamental para sua primazia nas expansões marítimas, elencando algumas das consequências que essa expansão trouxe ao mundo, especialmente no que diz respeito às novas concepções estéticas e filosóficas na Europa. Na sequência do capítulo, apresentam-se alguns dados conhecidos acerca das personagens históricas de Camões, protagonista da peça, e Diogo do Couto. O segundo e terceiro capítulos, "Abrem-se as Cortinas" e "A Viagem e seus Desdobramentos", destinam-se à análise interpretativa do texto teatral A Viagem - Camões - Poeta prático, de Helder Costa, respectivamente acerca do antes e depois da viagem do protagonista. O quarto capítulo, "Desenlace da Jornada", trata das fronteiras entre Ficção e História e suas implicações no texto de Helder Costa, sendo seguido pelas Considerações Finais do trabalho.

Arte e teatro no despontar dos tempos

A comunicação simultânea da compreensão e da experiência emocional é o domínio da arte.

BALL, 2014

O primeiro aspecto da análise do texto teatral de Helder Costa a ser considerado é seu caráter artístico, ou seja, a observação de que há preocupação estética em sua proposta de releitura do passado lusitano. Assim, faz-se necessário a retomada do conceito de arte para, em seguida, analisar o teatro e a tradição épica nos quais o dramaturgo está inserido.

O termo arte remete a inúmeros significados e a amplas considerações, tais como definição, critérios de reconhecimento e, até mesmo, projeções de seu futuro. A etimologia oferece um caminho promissor para a tessitura de algumas considerações a esse respeito.

A palavra arte vem do latim ars, que corresponde ao vocábulo grego tékne, cujo significado está relacionado a dois sentidos: modo de ser ou de agir e conhecimento especializado em alguma área. Alfredo Bosi, em seu livro Reflexões sobre Arte (1986), sugere que a arte seja interpretada como:

(...) um conjunto de atos pelos quais se muda a forma, se transforma a matéria oferecida pela natureza e pela cultura. (...) A arte é uma produção, logo supõe trabalho. Movimento que arranca o ser do não ser, a forma do amorfo, o ato da potência, o cosmos do caos. Techné chamavam-na os gregos; modo exato de perfazer uma tarefa, antecedente de todas as técnicas dos nossos dias. 
A palavra latina ars, matriz do português arte, está na raiz do verbo articular, que denota a ação de fazer junturas entre as partes de um todo. [grifo do autor] (1986, p. 14-5).

Como se depreende da citação, o conceito de arte, em sua origem, referia-se ao ato de transformar objetos e ideias, atribuindo-lhes uma forma particular de representação no mundo empírico. Este sentido de arte como trabalho de transformação estava essencialmente relacionado ao uso coletivo da palavra, visto que era utilizado tanto para se referir às atividades que visavam a provocar a comoção popular, quanto às atividades que atribuíam forma aos objetos, tais como artesanato e a modelagem da cerâmica. Artifex (aquele que produz arte) referir-se-ia, sem distinção, ao poeta e ao artesão. Em português, o termo foi bipartido, dando origem a duas palavras distintas em significado e uso: artista (aquele que produz trabalho intelectual) e artífice (aquele que produz trabalho manual). A arte, em suas diversas formas de manifestação, é um elemento de representação cultural, identitária, social e, fundamentalmente, histórica.

Diante disto, infere-se que a arte pode ser compreendida como um conjunto das diversas maneiras de atribuir forma concreta ao que se passa no plano mental do homem, ou seja, quando se refere à arte, remete-se a um modo significativo de tornar palpável uma ideia. A arte possibilita ao homem, não apenas pela fala, como também por meio de gestos, desenhos e sons, materializar suas ideias e sentimentos, sejam eles valores individuais, sociais, mundividência, projeções de futuro, dentre outras inúmeras possibilidades que a experiência humana abarca.

A proposta de interpretação de arte como trabalho de concretização do plano das ideias permite compreendê-la enquanto objeto de estudo vastíssimo, cujo nascimento impreciso opõe-se à sua perenidade, mediante o improvável esgotamento das formas de manifestação da experiência humana. Acredita-se que a capacidade de expressar-se por meio da arte, compreendida desse modo, seja uma característica essencial da espécie homo sapiens. Neste sentido, citam-se os primeiros registros que se tem de arte entre os povos primitivos.

Em meio às diversas interpretações possíveis para essas produções artísticas, uma delas dá conta de que as pinturas rupestres, datadas do período paleolítico, encontradas no interior de cavernas na região da atual Europa, eram empregadas como forma de comunicação entre os homens que habitavam a mesma caverna, além de serem um registro coletivo, que permitia preservar e transmitir aos descendentes informações a respeito de seus antepassados. Desde os primórdios, o homem raramente se manteve isolado dos seres de sua espécie, pois a convivência em grupo era o modo mais eficiente de garantir a sobrevivência. Assim, pode-se inferir que o homem não elaborava a representação de suas ideias e sentimentos de modo concreto exclusivamente para si, mas também para aqueles com quem dividia o mesmo espaço. 
A arte, em suas primeiras manifestações, não tinha como objetivo principal apenas a beleza ou fruição estética, mas estava profundamente relacionada à representação de uma coletividade humana em busca de sobrevivência e de uma melhor apreensão do mundo que a rodeava. Neste sentido, segundo Mircea Eliade: “(...) o mito (...) fornece os modelos para a conduta humana, conferindo, por isso mesmo, significação e valor à existência." (2007, p. 8). Deve-se considerar que os mitos não eram apenas histórias tradicionais, comuns a um determinado povo, espécie de modelo social.

Além da coletividade, é preciso também considerar que o modo de produzir arte é afetado pelo período histórico em que o artifex (aquele que produz arte) está inserido. Cada tempo compreende a arte de uma forma, seja como representação da experiência humana, inovação, estabelecimento e/ou quebra de padrões estéticos. O modo de compreender e produzir arte está relacionado à habilidade de captação das características essenciais do tempo em que ela é produzida, tornando-a significativa, não apenas para aquele momento histórico, mas também para o futuro.

Assim, a relação entre arte e seres humanos pode ser considerada essencial, visto que, de certa maneira, ela permite que a experiência individual possa ser compartilhada e perenizada na qualidade de símbolo de uma sociedade. Ao se pensar em qualquer civilização antiga, virá à mente, quase que instintivamente, algum elemento artístico-cultural que a simbolize.

Ernst Fischer, em A necessidade da Arte (1976), considera o fenômeno da arte como uma atividade intrínseca e necessária ao ser humano, tal qual a alimentação e a moradia. Segundo ele, o homem:

(...) quer ser mais do que apenas êle mesmo. Quer ser um homem total. Não lhe basta ser um indivíduo separado; além da parcialidade de sua vida individual, anseia uma "plenitude" que sente e tenta alcançar, uma plenitude de vida que lhe é fraudada pela individualidade e tôdas as suas limitações; um mundo mais compreensível e mais justo, um mundo que tenha significação. (...) anseia por unir na arte o seu "Eu" limitado com uma existência humana coletiva e tornar social a sua individualidade. (...) Sente que só pode atingir a plenitude se se apoderar das expectativas alheias que potencialmente lhe concernem, que poderiam ser dêle. $\mathrm{E}$ o que um homem sente como potencialmente seu inclui tudo aquilo de que a humanidade, como um todo, é capaz. A arte é o meio indispensável para essa união do indivíduo como o todo; reflete a infinita capacidade humana para a associação, para a circulação de experiências e idéias. (p. 12-3).

Partindo das considerações de Bosi acerca do conceito de arte anteriormente citadas, inferese que ela seja o veículo pelo qual se concretiza a experiência humana. Some-se a esta potencialidade a busca que Ernst Fischer sintetiza como sendo a necessidade da arte: um canal que 
torne coletivas as experiências que o indivíduo não consegue, no tempo de uma vida, ter com plenitude. Desse modo, compreenda-se arte como sendo duplamente um meio para a expressão humana transpor para o plano concreto o que se passa nas ideias, bem como uma coletivização das experiências, que, em princípio, são individuais, mas que, na essência, não o são, pois pertencem a todos, por terem sido, de algum modo, experiências humanas.

Após essa breve discussão acerca da arte enquanto representação das experiências humanas, sejam elas individuais ou coletivas, a pesquisa em questão terá como foco a quinta das artes tradicionais: o teatro.

Ao referir-se ao teatro, três significados distintos e evidentes surgem para o termo: o teatro enquanto espaço físico, onde as representações artísticas ocorrem; teatro (singular) como arte, caracterizado pelos elementos discutidos anteriormente, e o teatro (passível de uso no plural) enquanto modo como esta arte se apresenta no decorrer do tempo, considerando que não se mantém igual ao longo da História. Nesta última acepção, não haveria um teatro, termo único e atemporal, mas vários, pois estes seriam reconstruções e adaptações do que esta arte significou para cada um dos períodos a que pertenceu.

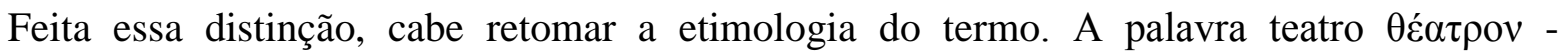
theatron é de origem grega, derivada de $\theta \varepsilon \alpha ́ o \mu \alpha$ - theoamai, que significa olhar com atenção, contemplar. Porém, não se trata do olhar comum do dia-a-dia, mas de (re)viver, por meio do olhar contemplativo e ávido, a experiência humana representada no palco. Contemplar o teatro, como o termo de origem sugere, é, antes de tudo, integrar-se a ele, ir além da cadeira do espectador, envolver-se nele e com ele. Vivencia-se Édipo, Medusa, Fausto, Hamlet, sem que o público se transforme neles.

Segundo o livro previamente citado de Fernando Peixoto:

(...) Os homens primitivos acreditavam ou no poder mágico de exercitar uma falsa ação antes de empreender a verdadeira, ou no poder prático de treinar astúcia e músculos para garantir o êxito no momento decisivo, neste caso, atribuindo à representação um sentido eminentemente prático, que não exclui a presença da beleza; imitando os próprios homens, buscavam observarem-se a si mesmos 'de fora', talvez utilizando o riso e o deboche como embrião de uma forma de a sociedade autocriticar-se através da representação de seus costumes cotidianos (...). (2012, p. 13).

O teatro é a atmosfera que permite despir as máscaras sociais, para que se possa utilizar outra, com a qual se vive o que não é particular, mas, ainda assim, vive-se intensamente a experiência coletivizada durante o espetáculo teatral. Esse mecanismo de vivenciar outra identidade, sem perder a original, está presente desde a mais tenra idade nos seres humanos. Dá-se 
vida a bonecos e objetos, para que, por meio deles, vivenciem-se experiências que seriam impossíveis de serem, de fato, vividas por nossa identidade primeira. Nesse sentido, a representação permite a reestruturação e o reconhecimento do indivíduo.

Desde as civilizações primitivas, tem-se notícia de rituais religiosos que envolviam a representação como forma de estruturar e simbolizar as crenças de um grupo. Ainda no livro de Fernando Peixoto, indica-se que:

(...) desde cedo os homens sentem a necessidade do jogo, e no espírito lúdico aparece a incontida ânsia de "ser outro", disfarçar-se e representar-se a si mesmo ou aos próprios deuses ou assumir o papel dos animais que procura caçar para sua sobrevivência, às vezes inclusive fazendo uso de máscaras; e ainda, ao que tudo indica, o jogo teatral, a noção de representação, nasce essencialmente vinculada ao ritual mágico e religioso primitivo. (2012, p. 12-3).

O grau de acessibilidade a esses rituais de representação estava diretamente relacionado ao valor religioso consolidado por eles. $\mathrm{Na}$ medida em que eram largamente aceitos, tornavam-se, consequentemente, acessíveis ao grande público. Índia, China, Creta e Egito são exemplos de civilizações que possuíam, em sua cultura cotidiana, as formas primitivas de representação aqui mencionadas.

Lentamente tiveram início as modificações, principalmente com a incorporação de novos elementos além dos religiosos, que permitiram dar forma ao que se conhece hoje como teatro. Esse longo e controverso caminho desde as raízes até a contemporaneidade passa pela Grécia, um dos mais importantes berços da dramaturgia. O teatro grego não escapa à tendência inicial de representação com objetivo religioso, em especial nas ocasiões festivas em honra à divindade dionisíaca.

Há duas versões mitológicas para o culto a Dionísio, deus do vinho, também chamado de Baco pelos romanos. A primeira afirma que o semideus teria sido fruto do romance entre Zeus, pai dos deuses, e Sêmele, mortal que, mal aconselhada por Hera, pede a seu amado que se mostre em todo o seu esplendor e, em razão de tal imprudência, é transformada em uma tocha. Zeus então lhe retira o feto do ventre e o coloca em sua perna, salvando-o. O semideus Dionísio nasce e é deixado por Zeus aos cuidados de entidades rupestres que o criarão. A outra versão dá conta de que Baco é fruto do relacionamento entre Zeus e Demêter (mortal). Os Titãs, incitados pela ciumenta Hera, teriam capturado a criança e a despedaçado, porém o pai do Olimpo teria tido tempo de salvar-lhe o coração, que, devorado por Sêmele, mortal e amante da divindade, teria dado à luz a Dionísio.

O mito do Deus do vinho tinha uma importância significativa nos festivais gregos, pois sua figura evidenciava a superação do humano sobre o fatídico destino. Durante as festividades 
dedicadas à divindade, havia rituais regados a muito vinho, cujo objetivo principal era a representação da vitória do humano sobre a morte. Em meio a delírios, ocorria uma transformação, em que os participantes sentiam-se quase como deuses, capazes de vencer qualquer obstáculo, inclusive o destino. Acreditava-se que aqueles que eram possuídos por Dionísio deixavam de agir por si mesmos, cessando de empregar a racionalidade, sendo nomeados hypokrités (ator, dissimulador), por representarem um papel que não era o seu, mas o de um deus.

As personagens do teatro grego representavam o constante intento humano de ultrapassar sua medida e seus limites para se tornar herói. No entanto, essa tentativa ofendia os verdadeiros imortais, que castigavam o hypokrités, aquele que estava possuído pelo delírio, acreditando-se deus, sem domínio de suas faculdades mentais, por isso era levado ao cumprimento da moira (destino), normalmente trágica. A necessidade de ir além dos limites humanos, ainda que se soubesse que isso geraria severa punição divina por tal intento, é um dos temas mais frequentes da tragédia grega.

Segundo Carlinda Fragale Patê Nuñez, em seu artigo, intitulado O teatro grego, presente no livro O teatro através da história (1994), há três aspectos básicos do teatro dessa época a serem considerados: a invenção, do ponto de vista psicológico, pois se tratava de uma emoção desconhecida até então, especialmente no que dizia respeito ao domínio de temas míticos como o destino; a invenção, do ponto de vista institucional, uma vez que o teatro se tornou parte do calendário oficial da cidade, contando com a profissionalização de atores e patrocínio das figuras públicas nobres da época, a fim de garantir que todos os cidadãos pudessem participar do evento e consagrar o que se apresentasse de melhor; e, finalmente, a inovação estética, pois o teatro passou a contar com palco, local específico que privilegiava a acústica, o cenário e os vestiários para os atores. Costuma-se atribuir à civilização grega o título de berço da dramaturgia, provavelmente porque os elementos mais significativos do teatro, tal como a plateia, o palco e os atores a encenarem uma história tenham, vigorosamente, lá se desenvolvido.

Cabe esclarecer, com base teórica em Anatol Rosenfeld (2006), a diferença entre o teatro clássico aristotélico e o brechtiano, no qual o texto de Helder Costa, objeto dessa dissertação, se embasa.

A teoria da divisão de gêneros aparece pela primeira vez, de acordo com Anatol Rosenfeld (2006), na República, de Platão, distinguindo as representações que eram puramente imitações, designadas tragédia/comédia, das em que o poeta desaparecia, chamadas ditirambo, que equivaleria ao gênero lírico, e, por fim, do estilo de representação que unia ambos os anteriores, nomeado epopeia. O livro Poética $(1981)^{2}$, de Aristóteles, traz à baila outra divisão de gêneros. Dois deles pertenciam ao gênero épico (narrativo por excelência), sendo eles a epopeia, na qual havia uma

\footnotetext{
${ }^{2}$ Data da versão consultada.
} 
terceira pessoa, espécie de narrador que tudo sabia sobre a narrativa, e a lírica, em que predominava a visão de mundo do próprio autor. O terceiro gênero, sobre o qual sua obra mais se debruçou foi o dramático, cujo cerne consistia na imitação por meio de personagens, sendo estas elevadas, na tragédia, ou rebaixadas, na comédia.

Fundamentalmente, o aspecto distintivo entre o dramático e o épico reside, segundo a divisão proposta por Rosenfeld, no significado adjetivo do gênero em questão, ou seja, uma peça teatral pode perfeitamente ter a estrutura dramática, porém apresentar aspectos narrativos, tais como a presença de um narrador ou de cenas que se passem no passado, fora de uma ordem cronológica que não permita a unidade essencial do drama aristotélico. Dessa maneira, o épico tende a tratar do passado, visto que dispõe de uma espécie de Deus-onisciente, que não se identifica com as personagens, mas estabelece uma relação de oposição entre sujeito e objeto. Já no que tange ao dramático, o mundo é representado por um viés autônomo, sem a interferência de um sujeito, por isso situado no presente contínuo da ação. "Teatro, no dizer de Aristóteles, é a mais política de todas as artes porque se situa no espaço em que os homens vivem em relação." [grifo do autor] (BALL, 2014, p. 10).

Porém, ao considerar, ainda que brevemente, o aspecto épico, no sentido de narrativa, este permeou, em maior ou menor medida, a História do fazer teatral. Como demonstrou Anatol Rosenfeld, no livro já citado (2006), o filósofo alemão Friedrich Hegel creditava o teatro como a dialética das artes, sendo os gêneros épico e lírico, respectivamente, tese e antítese da síntese que constituiria o drama. Porém, supor que esta última "supera" as anteriores se mostra equivocado, tendo em vista a manutenção ou, por vezes, a retomada ou fusão de elementos que pertenceriam a esses dois gêneros supostamente "inferiores". O próprio coro, elemento-chave do teatro aristotélico, se constitui como "a voz do autor", recurso este predominantemente épico.

No teatro medieval, episódios importantes da vida de Jesus Cristo, que costumavam ser narrados, passaram a ser dramatizados, primeiro pelos próprios clérigos, depois pelos cidadãos. $\mathrm{Na}$ mesma época, os mistérios medievais constituíam representações que dramatizavam um todo de fundo religioso, desde a Gênese até o Juízo Final. No entanto, a essas dramatizações associavam-se música e coro, em substituição a um narrador explícito. De acordo com Anatol Rosenfeld, houve variação nos aspectos épicos, em sentido narrativo, porém sua presença continuou por existir.

Durante o Renascimento, os valores greco-romanos foram revisitados, gerando inúmeras tentativas de espetáculos dramáticos que se apoiavam firmemente nos princípios aristotélicos de unidade de ação, tempo e espaço, justificados como ponto principal da verossimilhança na representação do fantástico. O palco à italiana é um exemplo de como a concepção de ilusão ganhou força durante esse período, visto que separava o público dos atores, com o intuito de manter 
a distância e, por isso, a sensação de que havia uma "quarta parede", em que a plateia não exercia papel relevante, pois os atores representavam para si próprios. Mesmo nesse modelo de representação, visivelmente de estrutura dramática, são reconhecíveis alguns elementos épicos, tais como o prólogo, os epílogos e as alocuções intermediárias que pressupunham em si o conhecimento do passado e do futuro, para além do que se desenvolvia no instante da representação teatral, aspecto predominante do narrador que tudo sabe, épico por excelência.

$\mathrm{O}$ aspecto didático, no sentido de trazer um ensinamento ao espectador, pode ser facilmente notado em Gil Vicente, cujos autos narrativos propiciam certo distanciamento entre a representação e o público, porém buscam que a plateia "aprenda" regras de conduta moral.

Já o teatro barroco apropriou-se dos efeitos ilusórios do teatro clássico para direcionar o público a compreender a representação como um artifício enganoso, por isso profano. Dentre os aspectos épicos que se constatam, cabe ressaltar a introdução de todo um maquinário que visava evidenciar a irrealidade daquelas representações dramáticas.

Ainda historicizando acerca do percurso do teatro, com base em Anatol Rosenfeld (2006), cita-se o teórico alemão Lessing, que questiona o éloignement, ou seja, o distanciamento entre o tempo em que as representações ocorriam e o público a quem se dirigiam, visto que é a burguesia quem vai ao teatro ver representar histórias em que há pouco ou nenhum reconhecimento quanto às personagens, posto que são, em sua maioria, advindas do teatro clássico ou religioso.

No período que segue, tanto no Pré-Romantismo quanto no Romantismo, a tendência do teatro é a fusão de gêneros, ou seja, a adoção de uma estrutura dramática, porém que não se ativesse às unidades de tempo, espaço ou ação, mas estivesse mergulhada na visão do eu (lírica), expressa pela narração (recurso épico).

No período Naturalista, destaca-se a representação de um homem que é "influenciado pelas ciências biológicas e sociais" (ROSENFELD, 2006, p. 89) e, por isso, determinado por fatores que lhe são anônimos e impossíveis de controlar, tal como o ambiente. Destaca-se, nesse período, a aplicação do tema taedium vitae, ou seja, o tédio da vida.

Segundo Anatol Rosenfeld, "personagens que vivem no passado saudoso ou no futuro sonhado, mas nunca na atualidade do presente, talvez seja o tema mais épico e menos dramático que existe" (ROSENFELD, 2006, p. 92), uma vez que o diálogo se torne inibidor da ação dramática, causando efeito retardante no desenvolvimento da ação. Tal recurso épico foi largamente utilizado por Tchecov, com a pretensão de, segundo Anatol Rosenfeld, "apresentar uma 'fatia' da realidade e não uma pequena totalidade em si fechada." (ROSENFELD, 2006, p. 96). Seguidos ao Naturalismo, encontram-se o Impressionismo, caracteristicamente marcado pela introdução do foco líriconarrativo, visto que a subjetividade é o ponto de partida para o que se projeta sobre o mundo, e o 
Expressionismo, que tinha estrutura dramática sem diálogos, com sequências de cenas do "real" mediadas pela visão do eu.

Cabe ainda mencionar o teatro asiático, fonte de pontos basilares do modelo de teatro épico brechtiano. O palco oriental era caracterizado como distante do real, anti-ilusionista por natureza. Tratava-se de uma representação despersonalizada, que causava o estranhamento, distanciamento do público em relação ao que era apresentado.

Segundo Sábato Magaldi, em $O$ texto no teatro:

Simplificando as inovações de Brecht, dir-se-ia que ele lançou as bases definitivas do teatro épico, que se opõe à forma tradicional, inspirada na "Poética" aristotélica. Do ponto de vista do intérprete, a técnica brechtiana resume-se em criar um "estranhamento" do texto, bem como em impedir a adesão "ilusória" do espectador, a fim de que este possa conservar a lucidez crítica. Do ponto de vista do texto, mergulha ele nos problemas sociais, denunciando, através da preocupação didática, os erros que impossibilitam uma vida feliz, na organização do mundo burguês. (2012, p. 270).

Bertold Brecht incorpora em sua prática teatral a técnica do distanciamento ou estranhamento, designada pelo termo Verfremdungseffekt, que tem por objetivo manter o caráter anti-ilusório entre o público e o que é representado, pois, assim, o espectador conseguiria contemplar o que lhe é apresentado de modo a pensar a respeito, transformando a experiência teatral em um momento de reflexão para além do espaço teatral, mais especificamente acerca da atualidade daquilo que lhe é representado. No que tange às personagens de Brecht, Sábato Magaldi aponta uma possível contradição, que adviria do fato de seu teatro optar pelo distanciamento como forma de manter a lucidez e, ao mesmo tempo, situar suas personagens em tempos distantes da realidade do público, o que:

De imediato, pareceria, com este método, que Brecht foge aos dados históricos específicos, que, no raciocínio marxista, devem ser a matéria da obra, analisada em seus aspectos positivos e negativos. Poder-se-ia asseverar que as criaturas transcendem a condição determinada no espaço e no tempo, para se esculpirem em símbolos universais - o que redunda quase na admissão de uma natureza humana permanente e eterna, tese tão pouco marxista. Brecht o faz, porém com outro intuito, o de distanciar o espectador da sua criação, a fim de que transpareça mais exemplar a consciência e julgamento do mundo atual. O público aproveitará, com a história de terras longínquas, a lição para o seu problema premente. (MAGALDI, 2012, p. 276-7).

Para que o Verfremdungseffekt seja efetivo, os atores não podem se "metamorfosear" nas personagens que representam, visto que projetam no palco um duplo estranhamento, aquele que 
advém do ator/personagem e aquele que se quer causar no espectador, pela ausência de reconhecimento. Assim, Brecht parte desta não identidade para que, a partir das ações das personagens, ocorra a manutenção da consciência crítica do espectador, a qual, ao longo do desenvolvimento do drama, acabará por direcioná-lo, e este seria o aspecto didático, ao reconhecimento da situação sociopolítica representada pela ação do homem enquanto agente da História. Desta forma, o espectador consegue compreender que, da mesma maneira o que é representado depende da "ação" das personagens, ele também, em sua realidade presente, se transforma em elemento modificador. O poder da mudança que o teatro épico brechtiano atribui ao espectador é o de que, a partir do "ensino" didático, construído por meio do movimento de estranhamento e posterior reconhecimento, há a efetiva transformação da realidade presente. Como bem sintetiza Ingrid Dormien Koudela, em Um vôo brechtiano:

A teoria de ensino-aprendizagem de Brecht é uma pedagogia dialética, que combina elementos indutivos e dedutivos na aprendizagem, colocando à nossa disposição um método de exame e ação sobre a realidade social. Seu conceito de peça didática pretende ensinar a "alegria da libertação" e tornar apreensível o ato de liberdade. (1992, p. 12).

Cabe, ao que se propõe nesse capítulo, tratar do autor e dramaturgo português Helder Costa, escritor da peça A Viagem - Camões - Poeta prático, objeto de estudo dessa dissertação.

Biobibliografia do autor

Helder Costa nasce em 6 de janeiro de 1939, na cidade de Grândola, região do Alentejo, em Portugal. Nos anos 60, torna-se estudante de Direito na Universidade de Coimbra, estabelecendo, nesse período, contato com o CITAC (Círculo de Iniciação Teatral da Academia de Coimbra). Em 13 de maio de 1962 integra, por castigo político, devido à participação em greves estudantis, a Companhia Disciplinar de Penamacor (prisão militar destinada a presos de delito comum, particularmente indisciplinados e violentos). Sai meses mais tarde, isento do serviço militar por questões de saúde. Continua seus estudos de Direito na Universidade de Lisboa, e, por opção política, decide dedicar-se a apoiar a deserção dos jovens que eram chamados para o Exército, uma vez que não concordava com a Guerra Colonial imposta pelo governo salazarista. Nesse período, cria e dirige o grupo Cênico da Faculdade de Direito, premiado nos anos de 1966 e 1967, no Festival Mundial de Teatro Universitário em Nancy (onde faz amizade com o grupo TUCA de São Paulo e com Chico Buarque). 
Em 1967, denunciado à polícia política, é obrigado a fugir de Portugal. Atravessa a nado o Rio Guadiana (na fronteira com a Espanha), dirigindo-se a Paris, onde se estabelece na casa de Zé Mario Branco, velho amigo de Coimbra. Frequenta o Institut d'Études Théatrales, da Universidade de Sorbonne, na capital francesa, onde aprende que o bom teatro deve ter "adereços simples, textos que apostam no contraditório e no conflito, e a ideia-base deve ser compreensível e muito junto do humor. Nem que seja uma coisa trágica, há um toque ou outro de graça". 3

Três anos mais tarde, em 1970, funda o teatro operário de Paris, que conta com atores imigrantes de diferentes origens. Após retornar a Portugal, em 1974, depois da Revolução dos Cravos, trabalha como assistente de encenação e é coautor, com Luís de Lima e Luís Francisco Rebello, do primeiro espetáculo criado após o 25 de abril: Liberdade, Liberdade, que estreia em 1974. Em 1975, torna-se professor de dramaturgia e encenação no Conservatório Nacional, de onde se demite por discordar da orientação pedagógica.

Em 3 de março de 1976, é fundado o grupo de teatro A Barraca, sediado então à Rua Alexandre Herculano. Hoje A Barraca encontra-se em um antigo cinema, recuperado com o nome de Teatro Cinearte, no Largo de Santos 2. Na ocasião, Helder Costa é convidado a fazer seu segundo espetáculo. A proposta de dramaturgia versa sobre Gil Vicente e Ruzzante ${ }^{4}$, dando início à linha de trabalho que o dramaturgo adotaria, por meio da qual se propõe a rever a História e a cultura de Portugal.

O nome A Barraca é uma homenagem ao grupo La Barraca, de Garcia Lorca, criado em 1936, ano da Guerra Civil Espanhola, ocorrida durante a República Espanhola, com o objetivo de difundir o teatro na Andaluzia.

$\mathrm{Na}$ apresentação do livro Fernão, Mentes?, de Helder Costa, consta um histórico d'A Barraca, em que se definem os objetivos e as propostas do grupo, que se caracteriza como "um teatro que combata o espetáculo alienante" (1982, p. 7). Segundo ele,

Pesquisando a nossa cultura na metáfora popular, bem como na nossa história e necessidades, fomos a pouco e pouco definindo as linhas do nosso trabalho, quer representando originais nossos, quer adaptando à nossa óptica e às nossas realidades originais estrangeiros, procurando divertir o público sem abusar dele, transportando para o palco o compromisso de desmontar a vida para ajudar a transformá-la. (COSTA, 1982, p. 7).

Aderindo à proposta de empregar o teatro como um importante difusor de cultura e promotor da reflexão, Helder Costa prossegue com seu projeto. Em 1976, A cidade dourada é

\footnotetext{
${ }^{3}$ Disponível em: www.espacoportugues.ch/pessoas_26.pdf. Acesso em: 13 jul. 2012.

${ }^{4}$ Angelo Beolco foi ator e escritor italiano de peças teatrais. Suas obras, em especial as comédias, retratavam a vida em Pádua durante o século XVI, tendo por personagem principal Ruzzante, apelido pelo qual ficou célebre.
} 
representada, seguida pela ousada estreia no Festival de Teatro da Guarda de Histórias de Fidalgotes e alcoviteiras, pastores e judeus, mareantes e outros tratantes sem esquecer suas mulheres e amantes, dramaturgia composta por textos de Gil Vicente e Ruzzante. Seguiram-se os sucessos Barraca conta Tiradentes, de Augusto Boal, O Congresso dos Pides e Um Inquérito, inseridos no livro coletivo Ao qu'isto chegou, ambos em 1977. Ainda no mesmo ano, são publicadas: A camisa vermelha, que emprega a metáfora das cores que se chocam, para repensar as políticas sociais; 3 histórias do dia-a-dia (O Jogo da Bola, A Sorte Grande, A Vaca Prometida) e Teatro operário, um manual do teatro ao qual esteve ligado em Paris.

Em 1978, o escritor leva aos palcos a encenação teatral com a qual recebe o prêmio de melhor contribuição artística no Festival Internacional de Sitges, realizado em Barcelona: Zé do telhado ${ }^{5}$. A peça é ambientada no Portugal de 1835, no reinado de D. Maria II, filha de D. Pedro IV, também imperador do Brasil. Porém, a personagem principal não pertence ao meio das figuras ilustres da nobreza, mas ao povo. José Teixeira da Silva, referido na peça por Zé do Telhado, é um ex-militar que se revolta contra o descaso do governo para com o povo. A partir de então, adere a um grupo de bandidos, vindo a comandá-los, transformando-se em uma espécie de Robin Hood, cujo lema é roubar dos ricos e repartir com os pobres. A personagem é um convite à reflexão acerca do desejo de vingança do povo oprimido por um governo imerso em aspirações absolutistas ultrapassadas.

Após o sucesso da peça anterior, em maio de 1979, estreia D. João VI, com texto e encenação de Helder Costa, sendo condecorado como melhor texto no Festival de Sitges e vencedor do concurso da ATADT (Associação Técnica e Artística de Descentralização Teatral). Há, inclusive, menção honrosa de melhor ator ao protagonista da peça, Mario Viegas. A representação teatral é ambientada no reinado de D. João VI, desde sua resistência ao trono até sua morte. Nessa peça, Helder Costa brinda seu público com uma visão bastante cômica, beirando o caricatural, acerca do comportamento indeciso e influenciável do monarca. A peça também retrata os percalços de sua vida conjugal com a infiel e conspiradora rainha Carlota Joaquina, bem como a tentativa de neutralidade, por parte do reino português, diante do conflito de interesses entre a França napoleônica e a Inglaterra, potência industrial dos séculos XVIII e XIX. A peça instiga à reflexão a respeito da incoerência política lusitana de um governo que busca a manutenção do poder em detrimento das necessidades do povo, especialmente durante a Corte Joanina.

Ainda no ano de 1978, é publicado Um Homem é um Homem - Damião de Góis, ambientado ao longo dos reinados das personagens de D. Manuel, D. João III e Cardeal D. Henrique. O texto

\footnotetext{
${ }^{5}$ Em virtude da grande quantidade de peças do autor, serão tecidos breves comentários apenas acerca daquelas que se proponham a ser releituras da história e/ou da literatura portuguesas.
} 
teatral reconta, sob o viés crítico, a vida da personagem histórica Damião de Góis, que fora criado e amigo do príncipe D. João III, privilégio este que o teria feito alcançar posições de prestígio. Após alguns anos, afasta-se da vida de luxo da corte para se dedicar aos estudos com Erasmo de Roterdã. A partir de então, a personagem passa a questionar os dogmas da fé católica e a moralidade dos governantes. A peça tece reflexões acerca da relação entre integridade moral e posição social.

A Viagem - Camões - Poeta prático, publicada no ano de 1979, foi finalista do prêmio Santiago Rusinol, durante o Festival de Sitges. A peça, objeto de estudo dessa dissertação, propõe o tratamento crítico do período das expansões ultramarinas, tendo como fio condutor do enredo a vida e a obra do autor de Os Lusíadas. A peça convida a refletir, por meio do emprego de recursos intertextuais na forma de teatro épico brechtiano, a respeito do significado mais profundo do período tido como áureo da História Portuguesa em relação à contemporaneidade.

No ano de 1980, dois textos teatrais significativos proporcionam, ainda mais, o reconhecimento internacional do autor: Preto no Branco $^{6}$, uma adaptação de Morte acidental de um anarquista, de Dario Fo, e É menino, ou é menina?, que trata com agudeza da obra de Gil Vicente. Desde então, Helder Costa tem brindado seus espectadores com inúmeros textos, tais como: Fernão, Mentes? (1981), que relê a vida e a obra de Fernão Mendes Pinto, refletindo acerca da condição de mentiroso, usualmente atribuída a esta personagem histórica; Tudo bem! Reflexões acerca do homem novo (1982) ${ }^{7}$; Pata de leão (1985); Calamity Jane, em parceria com Maria do Céu Guerra (1986); O príncipe de Spandau (1987); O diabinho da mão furada (1987); O Baile (1988); Dancing (1988); Mi Rival (1990); Uma floresta de enganos (1991), que trata da trajetória da personagem histórica de Gil Vicente na Corte Portuguesa sob o comando de D. Manuel e, posteriormente, D. João III. A peça apresenta forte crítica à postura conservadora, ou mesmo inquisitorial, do Clero e da Nobreza da época; Parabéns a você (1993); A balada da Margem Sul (1994); Viva la vida!, em parceria com César de Oliveira (1995); Gulliver (1996); O abrigo (1996); Marilyn, meu amor (1996); Queres ser ministro? (1997 e 2001); O incorruptível (1998); O mistério da camioneta fantasma (1999 e 2001), que retoma o episódio histórico em que foram misteriosamente massacrados os heróis da República. A peça busca investigar os motivos que teriam levado à impunidade os autores dos crimes e à punição os executores; Abril em Portugal (1999), que, a partir de cenas ilustrativas da conversa de três atores, reflete acerca das consequências da ditadura salazarista e das participações populares no governo; Ódio no Palácio Real (2002). Os Renascentistas (2004) promove o encontro de personagens históricas, escritores renascentistas que, por meio de suas vidas e obras, exemplificam o sentido real do humanismo;

\footnotetext{
${ }^{6}$ Cabe ressaltar que, devido à grande quantidade de peças do autor, serão tecidos breves comentários apenas acerca daquelas que se proponham a ser releituras da história e/ou da literatura portuguesas.

${ }^{7}$ Foram adotadas as datas de referência mencionada nas peças, porém tais datas são, muitas vezes, conflitantes.
} 
Bushlândia (2004); Que bom cu ele tem! (2006); As aventuras do menino Paulinho, A Borbulha e A Pessimista (2006). Mencionam-se outros textos, como Os bastardos de Salazar, que trata da revolução dos Cravos sob a perspectiva de diversas categorias da sociedade, tais como a do político, a do jornalista e a do homem comum. Obviamente demito-o trata da ditadura salazarista, a partir da candidatura de Humberto Delgado como líder da oposição ao regime. Devem ser citadas também as peças O professor de Darwin, As peúgas de Einstein, A barca do mundo, Antonio Aleixo, Conversas com gente famosa ${ }^{8}$, dentre outros textos. Todas estas peças foram construídas a partir de um cuidadoso trabalho de pesquisa, aliado à proposta teatral defendida pelo autor: "uma linha que se define por fazermos um teatro popular sem ser populista, fazemos um teatro culto sem ser elitista" (COSTA, 1982, p. 7).

Infere-se, a partir das palavras de Helder Costa, que o cerne de sua proposta teatral está na aliança entre cultura, sem seu caráter elitista ou excludente, e o acesso ao grande público. Nas palavras do dramaturgo, a proposta do grupo A Barraca:

(...) nos levou ao estudo da História e da Cultura, que nos conduziu a uma acçãotestemunho do nosso tempo, e que nos insere num campo de teatro internacional que, à falta de designação mais correcta e precisa, se pode definir por popular.

Teatro popular, porque sem ser etnográfico ou museológico, estuda e aprofunda as metáforas tradicionais populares, recorre à imaginação, ao rigor da simplicidade, ao poético, e ao mágico. Teatro popular também, porque se quer comunicativo e interveniente, porque acredita na evolução e no progresso, porque gosta de fazer rir e de se divertir. ${ }^{9}$

O modelo de teatro épico brechtiano, eleito pelo dramaturgo português como ferramenta de releitura do passado glorioso de seu país, sugere que haja, ao longo de todo seu texto teatral, um constante movimento de estranhamento entre atores e público, objetivando despertar, pelo método do anti-ilusionismo, a consciência crítica do espectador. No entanto, diferente do que fazia o encenador da companhia Berliner Ensemble, Helder Costa não traz ao palco o desconhecido, mas sim um passado longínquo, que é efetivamente parte da cultura e da identidade lusitana, trazendo, portanto, em si o aspecto da familiaridade.

Neste sentido, o Verfremdungseffekt de Helder Costa relaciona-se à percepção de que:

\footnotetext{
${ }^{8}$ Há duas razões que justificam a presença de textos sem data. A primeira delas deve-se ao fato de não ter sido possível o contato direto com o texto. A segunda se relaciona à ausência de data nos textos disponibilizados pelo próprio autor, via correio eletrônico.

${ }^{9}$ Disponível em: http://www.abarraca.com/index.php?option=com_barraca\&view=ecos\&Itemid=7. Acesso em: 10 jan. 2015.
} 
(...) o problema fundamental deste país, era o problema da existência da Censura e o problema da falta de educação, de instrução e de conhecimento. Decidimos fazer uma programação, a maior parte das coisas ou praticamente todas, fui eu que escrevi e tinham a ver com a história e cultura de Portugal. (...) o processo é esse. Criar os temas e conseguir desmontar as vigarices, as mentiras que tinham sido ditas durante dezenas de anos. Isto foi um vector fundamental do nosso trabalho. Todos os anos fazemos peças que tenham a ver com a História de Portugal e com a cultura de Portugal, pode ser o Camões, pode ser Gil Vicente, O Damião de Góis, figuras de cultura, mas também os reis, o Zé do Telhado; quer dizer, são temas que tem a ver com a vida das populações, com os monarcas... Isto é um vector. O outro, que também fazemos, todos os anos, são peças que têm intervenção directa sobre a situação actual, política, sociológica. ${ }^{10}$

Infere-se que, por tratar de personagens familiares ao imaginário coletivo português, o distanciamento do teatro brechtiano no texto de Helder Costa possivelmente não ocorra pelo assunto tratado, mas pelo modo como os aspectos familiares da História de Portugal são relido em $A$ Viagem - Camões - Poeta prático, o que será analisado com maior atenção em capítulos subsequentes.

Embora o teatro, para ser completo, pressuponha a performance dos atores, no momento em que o texto encontra sua máxima expressão, este trabalho, por pertencer à área de Literatura, opta por se debruçar em desvelar o próprio texto teatral como instrumento para despertar o espectador enquanto agente transformador da História, assim como sugerido pela concepção brechtiana de teatro.

O teatro épico desenvolvido por Bertold Brecht é resultado de distintas fases do poeta e dramaturgo. O jovem alemão teve contato com a corrente historicista do Naturalismo e com o Expressionismo, em partes identificáveis ao Niilismo, consequência direta da devastadora Primeira Guerra Mundial. Assim, Brecht iniciou um movimento de experimentação que perpassou do elogio niilista ao realismo social, com breves contatos com o teatro do absurdo, alcançando a grande ópera. Desse laboratório, surgiram as chamadas “peças didáticas”. Brecht já estava em contato com Erwin Piscator, cujo conceito de teatro didático ligava-se ao fato de que essa arte deveria alargar a ação e ter seus pressupostos claros, para além dos limites do dramático. Sendo assim, a segunda fase do dramaturgo alemão consistiu na sedimentação de suas experiências anteriores e em seu contato com Piscator. Em sua fase mais madura, Brecht evidenciou em suas peças a discordância de alguns aspectos do teatro didático, visto que já desenvolvia seu próprio conceito de épico, cuja característica essencial reside no apelo à razão do espectador, e não ao sentimento, como a tradicional forma dramática aristotélica. Segundo Aderbal Freire-Filho, em seu livro Estudos sobre teatro:

${ }^{10}$ Disponível em: www.espacoportugues.ch/pessoas_26.pdf. Acesso em: 13 jul. 2012. 
A ausência de uma quarta parede deixou de corresponder à ausência de um narrador. E não era somente $\mathrm{o}$ fundo que tomava posição perante os acontecimentos ocorridos no palco, trazendo à memória, em enormes telas, outros acontecimentos simultâneos, ocorridos em algum lugar; justificando ou refutando, através de documentos projetados, as falas das personagens; (...) Também os atores não consumavam completamente a sua transformação, antes mantinham uma distância em relação à personagem, e incitavam, até ostensivamente, a uma crítica. Não mais era permitido ao espectador abandonar-se a uma vivência sem qualquer atitude crítica (e sem consequências na prática), por mera empatia com a personagem dramática. A representação submetia os temas e os acontecimentos a um processo de alheamento indispensável à sua compreensão. Em tudo o que é evidente, é hábito renunciar-se, muito simplesmente, ao ato de compreender. (...) O espectador do teatro dramático diz: - Sim, eu também já senti isso - Eu sou assim. - O sofrimento deste homem comove-me, pois é irremediável. É uma coisa natural. - Será sempre assim. - Isso é que é arte! Tudo ali é evidente. - Choro com os que choram e rio com os que riem.

O espectador do teatro épico diz: - Isso é que eu nunca pensaria. - Não é assim que se deve fazer. - Que coisa extraordinária, quase inacreditável. - Isto tem que acabar. - O sofrimento deste homem comove-me, porque seria remediável. - Isso é que é arte! Nada ali é evidente. - Rio de quem chora e choro dos que riem. (2005, p. 66-7).

Marxista convicto desde os anos vinte, Brecht vê no teatro um instrumento precioso de conscientização e politização popular. Para tanto, coloca no palco o que constantemente nomeia como experimentos sociológicos, cujo objetivo é trazer ao público a percepção de que as desgraças do homem não têm origem no destino, mas na História e, por isso, podem ser modificadas, interferindo no futuro da sociedade. O dramaturgo recria o teatro épico a fim de obter um instrumento por meio do qual fosse possível colocar em cena a natureza política das discussões acerca da realidade social.

Justificativa da escolha da peça

De acordo com Aristóteles, "Imitar é natural ao homem desde a infância - e nisso difere dos outros animais, em ser o mais capaz de imitar e de adquirir os primeiros conhecimentos por meio da imitação - e todos têm prazer em imitar" (1981, p. 21-2). Essa afirmação é o ponto de partida do filósofo para a posterior divisão de gêneros. Esse assunto foi tratado na primeira parte do capítulo, que ilustra o percurso do teatro épico até Bertold Brecht, molde para a composição de Helder Costa no texto A Viagem - Camões - Poeta prático, que estabelece evidente diálogo entre a Literatura e a História portuguesas. 
Desde a Antiguidade, era comum que os autores estabelecessem em seus textos "diálogos" com obras ou textos de outros autores, antigos ou contemporâneos. Porém, não havia a valoração negativa que, na atualidade, se entende por "cópia". Com frequência, paradigmas textuais eram reproduzidos em partes ou, até mesmo, integralmente, no intuito de estabelecer um diálogo entre ambos os textos. Enquanto na filosofia aristotélica, o imitar é uma característica inata do serhumano, portanto natural, na visão de Horácio, autor de Arte Poética (1981), o conceito de imitação adquire também aspecto da emulação, que consiste na tentativa de superação de um modelo considerado valoroso. Além das motivações já mencionadas para o diálogo entre textos, podem ser citados o vitupério do texto paradigmático (ridicularização), o reconhecimento do valor de um texto ou, ainda, a necessidade de respostas que o texto paradigmático exigia em si mesmo.

Passado algum tempo, o diálogo entre textos diferenciou-se completamente da cópia com finalidade de emulação, que passou a ser vista com desaprovação. A conversa estabelecida entre textos se manteve, ainda que de maneira indireta, com a finalidade de criticar, propor releituras ou facilitar a compreensão dos textos.

Nesse ponto, cabe deslocar-se até o século XX e recordar os estudos que se desenvolviam acerca do discurso, especialmente na vertente bakhtiniana. Conforme Diana Luz Pessoa de Barros, a definição de Bakhtin acerca do enunciado:

(...) aproxima-se da concepção atual de texto. O texto é considerado hoje tanto como objeto de significação, ou seja, como um "tecido" organizado e estruturado, quanto como objeto de comunicação, ou melhor, objeto de uma cultura, cujo sentido depende, em suma, do contexto sociohistórico. Conciliam-se, nessa concepção de texto ou na idéia de enunciado de Bakhtin, abordagens externas e internas da linguagem. $O$ texto enunciado recupera estatuto pleno de objeto discursivo, social e histórico (2011, p. 1).

Ainda sob a perspectiva do formalista russo, haveria uma "conversa" "que independe de qualquer intencionalidade de seu enunciador/autor, diga-se que “(...) é o diálogo entre muitos textos da cultura, que se instala no interior de cada texto e o define". (BARROS, 2011, p. 4).

Dialogismo, segundo Bakhtin (2010, p.214), seria a condição de sentido do discurso, seja ele de que esfera for. Nas palavras do autor:

Sempre que no contexto do autor há um discurso direto - o de um herói, por exemplo -, verificamos nos limites de um contexto dois centros do discurso e duas unidades do discurso: a unidade da enunciação do autor e a unidade de enunciação do herói. Mas a segunda unidade não é autônoma, subordina-se à primeira e dela faz parte como um de seus momentos. (...) O discurso da personagem é elaborado precisamente como o discurso do outro, como o discurso de uma personagem 
caracterológica ou tipicamente determinada, ou seja, é elaborado como objeto da intenção do autor, e nunca do ponto de vista da própria orientação dessa personagem centrada no referente. (2010, p. 214).

No caso da Literatura, o teórico afirma que a percepção desse mecanismo, intrínseco ao discurso, é o ponto-chave para aproximar-se da produção do sentido; em outras palavras, ele assevera que só seria possível depreender o que um discurso/texto significa a partir do conhecimento desse diálogo, inerente ao próprio texto.

Segundo Julia Kristeva, no prefácio da tradução francesa de A Poética de Dostoievski:

Bakhtin é um dos primeiros a substituir o recorte estático dos textos por um modelo onde a estrutura literária não é/não está mas se elabora em relação a uma outra estrutura (...) Cruzamento de superfícies textuais, diálogos de várias escrituras (...) todo texto é absorção e transformação de outro texto. No lugar da noção de intersubjetividade instala-se a noção de intertextualidade e a linguagem poética lêse pelo menos como dupla (Apud LOPES, 2011, p. 71. In BARROS, Diana; FIORIN, José (org). 2011).

Cabe ressaltar que o dialogismo no sentido bakhtiniano seria a propriedade de um discurso de estar, assim que enunciado, em diálogo com todos os outros discursos que, de alguma maneira, se relacionam a ele, sendo esta propriedade inerente ao discurso, independente da vontade do emissor.

Julia Kristeva, na década de 1960, cunhou o conceito de intertextualidade, em correspondência ao termo dialogismo, difundido por Bakhtin, cuja inovação estava em nomear o diálogo entre textos, tomando por referência a alteração parcial ou integral de um texto paradigmático, ou seja, a intertextualidade se concretizaria pela característica de ser uma espécie de colcha de retalhos, na qual os "tecidos" originais aparecem parcialmente modificados, semelhantes ou completamente ao avesso de como eram em seu "tecido" original.

O recurso da intertextualidade, muito embora ocorresse mesmo sem uma denominação para o fenômeno, tornou-se um importante instrumento para a releitura de textos clássicos, velhos conhecidos do público leitor, que são apresentados com nova roupagem graças a esse recurso linguístico.

A peça teatral em análise neste estudo inscreve-se no rol de textos que se valem da intertextualidade como veículo de crítica, mais especificamente no que tange à reanálise históricoliterária do paradigma escolhido, que, neste caso, são as grandes navegações portuguesas realizadas entre os séculos XV e XVI, quando o pequeno país da Península Ibérica dominou o mundo até então conhecido. 
A proposta de uma "nova versão" das navegações ultramarinas por si só não justificaria a peça como foco desta dissertação. Porém, o modo como os mecanismos intertextuais são associados à mundividência de Helder Costa, por meio do uso do teatro brechtiano como ferramenta para tal, torna-a bastante promissora; mas se considerar-se o contexto histórico em que o dramaturgo propõe esta releitura, de fato tem-se um objeto de estudo que promete tecer uma ponte singular entre o Portugal glorioso, que posteriormente declinou, e o Portugal que acabava de sair da ditadura salazarista.

Desde o título, A Viagem - Camões - Poeta prático, estabelecem-se diálogos intertextuais com a personagem histórica de Camões, que eternizou em seus versos a expedição de Vasco da Gama às Índias. A personagem do poeta é o guia e praticante da viagem mencionada no título, sendo sua vida e obra o ponto de partida para a releitura proposta. Ademais, o texto teatral também evoca o diálogo com o livro de Diogo do Couto, intitulado O Soldado Prático, que trata das condições de vida dos portugueses na Índia, denunciando os enganos das conquistas lusitanas em territórios ultramarinos.

O caráter épico brechtiano da peça choca-se a princípio com o nostálgico e, aparentemente, feliz pretérito evocado na releitura. Helder Costa dispõe-se a revisitar o passado sem reverenciá-lo, com o intuito de retomá-lo no presente, para não apenas reformular o conhecido, mas também despertar o espectador contemporâneo, a fim de conscientizá-lo de que a História não se fez, mas ainda está e sempre estará por ser feita. 


\section{ENREDO E PERSONAGENS}

Não há texto sem contexto. OLSHEWSKY, 1991.

A epígrafe desse capítulo sinaliza o pressuposto de que o texto é dialógico, pois tem, em seu interior, aspectos que lhe são intrínsecos, tais como o diálogo com outros textos, independente da vontade do autor, além de elementos sociais, políticos e históricos, diluídos ou evidenciados por meio da intertextualidade, que, no caso de Helder Costa, serve como recurso para a releitura que o encenador português propõe.

Com o objetivo de compreender a mundividência do dramaturgo contemporâneo, torna-se obrigatória a apreensão do contexto histórico português, desde sua formação como reino independente, quando começa a desenvolver sua identidade, até tornar-se o centro do mundo, contexto no qual se ambienta a peça, cujo final remonta à perda da autonomia portuguesa, então subjugada pelo domínio espanhol, que marcaria profundamente a Nação Lusitana.

O estudo debruça-se sobre os dados históricos antes de analisar como a releitura do texto teatral é proposta, a fim de estabelecer em que medida o dramaturgo Helder Costa "pactua" ou “diverge" da visão tradicionalmente conhecida desse período da História Portuguesa, na tentativa de reler criticamente o passado, por meio da ficcionalização.

\subsection{Um reino em formação}

Ao fazer referência à Idade Média europeia, tem-se a tendência de associar esse período aos moldes carolíngios ${ }^{11}$ de organização social feudal, em que as relações de vassalagem e a descentralização do poder real eram regra. Porém, o caso português exige um olhar mais atento, a fim de que sejam consideradas certas peculiaridades. Não se mencionará o período que antecede à existência de Portugal como Estado. Partir-se-á do final do século XI, quando as batalhas entre os reinos de Castela, Aragão, Navarra e Leão já estavam em suas fases mais decisivas.

No final do século XI, antes das Cruzadas, chegam à Península Ibérica alguns contingentes franceses que combatiam os infiéis. Um dos visitantes é Raimundo, conde de Amous, que, após sucessivas visitas, acaba por se estabelecer. Casa-se em 1091 com Urraca, única filha legítima do

\footnotetext{
11 Adjetivo relacionado à dinastia de Carlos Magno, que governou de 742 a 814, rei dos francos e imperador do Ocidente.
} 
“imperador", título concedido ao suserano com mais terras na época: Afonso VI, rei de Leão, Castela, Galiza e Portugal. Ao novo genro, o imperador concede o governo (tenência) de Galiza.

Henrique, primo de Raimundo, empreende conquistas militares de sucesso e recebe, por seus serviços, o governo de Portugal e Coimbra, sob o regime de obrigações de vassalagem. Com o privilégio, vem-lhe também o casamento com Tarasia (Teresa), bastarda e favorita de Afonso VI. Ao fim da vida, o imperador demonstra suas pretensões de passar a Coroa ao filho ilegítimo, Sancho. Diante desta possibilidade, Urraca e Raimundo aliam-se a Henrique (1105), com o objetivo de assegurar a sucessão do trono, porém há escasso tempo para consolidar o acordo, pois Raimundo morre em 1107, Sancho é assassinado em 1108 e Afonso VI falece em 1109.

Afastada a possibilidade de um bastardo assumir o trono, são respeitadas as ordens testamentárias. Urraca herdaria o título, mas seu filho só governaria se ela se casasse novamente, o que faz em 1109, com Afonso I de Aragão. Nesse período conturbado por disputas acirradas entre aragoneses, leoneses, castelhanos e galegos, o conde D. Henrique evita marcar posições definitivas nos impasses e, com isso, consegue abandonar sutilmente os deveres feudais e manter-se autônomo. Tendo D. Henrique falecido em 1112, a esposa, D. Teresa, mantém a política de seu esposo, de modo geral, conservando sob seu domínio o Estado de Portugal quase que inteiramente.

A morte de Urraca em 1126 traz ao trono seu filho, Afonso Raimundes, sob o nome de Afonso VII. Este imprime campanhas militares que objetivam rememorar a tia, D. Teresa, acerca de suas obrigações feudais para com ele, agora imperador. Nesse cenário, surge Afonso Henriques, filho de D. Henrique e D. Teresa, cuja persistência e liderança lhe valem a vitória contra o primo na Batalha de São Mamede, no ano de 1128. Entre 1128 e 1137, Afonso VII e Afonso Henriques travam constantes disputas, especialmente pela expansão territorial dos feudos sob seus comandos. O herdeiro de D. Henrique aspira ao título de rei (rex). Conforme elucida Oliveira Marques, em História de Portugal:

Desejar ser rex não era loucura e tinha já precedentes. Antes de 1028, os nobres castelhanos pediram licença ao rei de Leão para que seu conde Garcia Sánchez assumisse o título de rex, visto que ia casar com a filha do rei. Depois de 1035, Ramiro Sánchez, filho ilegítimo de Sancho de Navarra, tornou-se rex em Aragão. (...) Afonso Henriques, cujo Estado era maior do que qualquer dos dois, podia perfeitamente aspirar ao mesmo título. Rex não implicava independência no sentido de uma quebra completa dos laços feudais. Para mais, Afonso VII de Leão e Castela fizera-se solenemente proclamar "imperador" nas cortes de Leão em 1135. Ora um imperador podia e devia ter reis como vassalos. Era coisa que só lhe enaltecia o prestígio e o poder. (1978, p. 65-6). 
Mediado por um legado papal, fixa-se em 1143 um acordo, no qual se concedia o título de rex a Afonso Henriques e este, em contrapartida, deveria dispor de auxílio militar a Afonso VII de Leão sempre que necessário. O próximo passo do soberano português rumo à independência se dá por meio da encomenda de Portugal à Santa Sé, a fim de obter o reconhecimento papal para seu reino (regnum), oferecendo, em troca, o pagamento de tributo anual.

Embora a contribuição tenha sido aceita, o papa Lúcio II não pretendia estimular tentativas de separação, ou mesmo criar situações conflituosas no que dizia respeito aos interesses de seu favorito Afonso VII de Leão, apenas referindo-se a Portugal como dux portucalensis.

Em 1146, Afonso Henriques casa-se com Matilde, filha de Amadeu III, conde de Saboia, almejando a manutenção dos laços de tradição com a região de Borgonha. Casa seus filhos com governantes da Península Ibérica, garantindo, assim, um período considerável de paz. Contudo, a morte de Afonso VII de Leão e Castela, no ano de 1157, vem dar fỉm à estabilidade reinante. Os domínios do imperador morto são divididos entre seus dois filhos: Fernando II herda Leão e Galiza, e a Sancho III é concedido o reino de Castela.

$\mathrm{Na}$ tentativa de manutenção da paz entre os reinos, é celebrado o casamento entre Urraca, filha de Afonso Henriques, e Fernando II, de Leão e Galiza, porém o matrimônio é anulado sob o pretexto do parentesco, dando novo início aos desentendimentos. A separação dos reinos de Castela e Leão dura até 1230, refletindo no abandono do título de 'imperador' pelo soberano, bem como no enfraquecimento definitivo da relação de vassalagem, que Afonso Henriques, desde a concessão de suas terras, lutava para desobrigar-se de cumprir.

Apenas em 1179 o papa Alexandre III, a partir de maiores tributos e concessões de privilégios à Igreja, reconhece Afonso Henriques como rei e seu Estado como reino. Nasce Portugal como Nação independente, sob o reinado de Afonso I.

\subsubsection{Dinastia de Borgonha}

Em virtude de uma queda, que o impediria permanentemente de voltar a montar cavalos, o rei Afonso Henriques acaba por passar os últimos quinze anos de sua vida recolhido, deixando a cargo de seu filho, Sancho I de Portugal, a continuidade das investidas militares contra os mouros. Esse assumiu o trono com a morte do pai, Afonso Henriques, em dezembro de 1185. A política de fortalecimento das relações com Aragão continua, com o novo rei casando-se com Dulce de Aragão, irmã do soberano reinante daquelas terras. Procede do mesmo modo com seus filhos, realizando matrimônios com finalidades diplomáticas, de acordo com os interesses da Coroa. Durante seu reinado, preocupa-se com o repovoamento e desenvolvimento de regiões conquistadas, 
com destaque para Lisboa e Santarém. Sancho I envolve-se em conflitos com o vizinho Leão, além de desentendimentos com o Clero secular. Embora menos liberal do que seus antecessores com as ordens religiosas e militares, o rei mantém o equilíbrio e as boas disposições durante seu governo.

Não se pode afirmar o mesmo acerca do reinado de Afonso II, terceiro rei de Portugal e herdeiro de Sancho I, cujo reinado se caracteriza por uma política belicosa, incluindo desentendimentos com o papa, que lhe geram a excomunhão em 1220, além de sangrenta guerra civil entre os anos de 1211 e 1214, como resultado do desrespeito às divisões territoriais designadas no testamento paterno. Ameaçado de ser considerado ateu (anátema) pelo papa Inocêncio III, reconcilia-se com a Igreja já à beira da morte, em 1223.

O sucessor do trono, Sancho II, caracteriza-se por seu pulso fraco, o que resulta em perdas e grandes concessões no Alentejo e parte do Algarve. Convencido pelo alto clero da incapacidade de governança do rei, o papa Inocêncio IV instrui que pessoas de sua ordem aceitem D. Afonso (conde de Boulogne-sur-Mer, no exílio desde a adolescência) como curador de Portugal. Assim que assume o novo cargo, este trava batalha contra o rei Sancho II, que acaba por refugiar-se em Castela, onde virá a falecer, em 1248.

O reinado de Afonso III, segundo filho de Sancho II, caracteriza-se por um período de reveses e mudanças nas estruturas sociais, a começar por nomear Lisboa a capital do reino. Sua linha sucessória é o marco de disputas que, sem causas aparentes, durariam alguns anos. De seu primeiro casamento com Matilde, condessa de Boulogne, nasce D. Dinis. Após o pedido de anulação do matrimônio, o rei casa-se novamente com Beatriz de Guillén, bastarda do rei de Castela, tendo com ela vários filhos, sendo o primogênito D. Afonso. Porém, a anulação do casamento só é concedida pela Igreja em 1263, após o rei já ter falecido, em 1258. Estabelece-se a disputa pela Coroa entre D. Dinis e D. Afonso. Aquele sai vitorioso e legitimado, em função de suas concessões, que privilegiam as ordens religiosas e militares. Faz de seu reinado um período de prosperidade, ao que muitos atribuem o título de apogeu da Idade Média Portuguesa. O soberano cria uma nova ordem religiosa nacional, que se tornaria uma das melhores armas a serviço do rei.

Segundo o historiador A. H. de Oliveira Marques, em História de Portugal: "O Portugal dos finais da Idade Média apresentava muitas características próprias, consequência natural do encontro e da fusão de estruturas do Norte com estruturas do Sul.” (1985, p. 151). O Norte se caracteriza pela dominante presença do Cristianismo, sendo essencialmente rural, enquanto o Sul é predominantemente islâmico e urbano em sua organização populacional. O século XII é marcado pelos objetivos da Reconquista e de expulsão dos mouros, a partir da conquista de territórios estratégicos como Lisboa e Alcácer. Do reinado de Afonso III até o fím da Peste Negra, Portugal 
vive um processo complexo de união entre Norte e Sul, culturas deveras distintas dentro do mesmo país.

No tocante às relações de vassalagem, Oliveira Marques afirma que:

A vassalidade, como instituição, achava-se perfeitamente estabelecida em Portugal nos séculos XIII, XIV e XV. Em vez de fidelis, tão costumada anteriormente, foi vassallus (vassalo) que se passou a generalizar e a referir a todos os nobres na dependência directa do seu rei. A pequena extensão do País e o facto de ser o monarca um dos maiores proprietários dele explicam o número relativamente grande de vassalos directos e a consequente força do rei. (1978, p. 126).

O poder real exerce, embora de maneira não tão clara, o controle sobre tudo o que se processa nas senhorias, glebas que tinham a tenência de alguém designado pelo rei. Além disso, o monarca previne-se contra os abusos da Nobreza e limita com sutileza as intervenções da Igreja. Com o tempo, os reis portugueses, quase sem exceção, estabelecem limites cada vez mais bem definidos de seu poder e de sua governança.

Em meados de 1340, verificam-se preços bem mais altos do que em épocas passadas. Segundo Oliveira Marques (1974), não haveria qualquer prova fulcral de crise em Portugal. Ao que parece, a aristocracia gasta demais e tende à ruína, com problemas de adaptação à nova realidade dos poderes descentralizados, enquanto a burguesia está cada vez mais próspera e reivindica espaço e reconhecimento naquela sociedade.

Com a morte do rei trovador, D. Dinis, em 1325, advêm tempos difíceis, de um lado pela crise econômica, que já sinalizava sua força entre as décadas de 1320 e 1330, de outro pela inaptidão para a diplomacia do novo rei, D. Afonso IV, que se envolve em disputas onerosas. Além disso, o soberano cria novos conflitos com o casamento mal sucedido de sua filha, D. Maria, com o rei de Castela, Afonso X, quando, levado pelas queixas da herdeira, instiga opositores políticos contra o genro. Aliadas a esse cenário, as invasões mouras nas fronteiras espanholas e a Peste Negra, em 1348, quando cerca de um terço da população é vitimada, vindo a ampliar os efeitos desastrosos das constantes instabilidades no governo de Afonso IV. Para arrematar as insatisfações do rei, seu filho Pedro, sucessor do trono, apaixona-se por uma jovem chamada Inês de Castro. Essa, originária de poderosa família castelhana, tem seu romance eternizado na Literatura mundial. O rei, para evitar problemas como a influência espanhola na Corte, ou ainda a possível perda da independência portuguesa, manda executar a moça.

Pedro I sobe ao trono após a morte de seu pai, em 1357, e reina pacificamente durante dez anos, de 1357 a 1367. De acordo com Oliveira Marques, esse monarca: 
Mostrou-se uma figura típica dos finais da Idade Média, meio louco e depravado em moral, preocupadíssimo com a administração da justiça, em íntimo contacto com o povo, que o adorava apesar dos seus actos de crueldade e loucura. Parece ter feito pouco para refrear o poderio dos nobres, mas foi, no entanto, temido por eles. (1978, p. 178).

A relação da Coroa com a Igreja também é minada por desavenças, especialmente após a negativa de publicação de bulas papais no país pela falta de autorização do monarca. Extensivamente, nacionalizam-se ordens religiosa-militares, dentre elas a de Avis ${ }^{12}$, na qual o rei investe seu filho bastardo, D. João, no mestrado ${ }^{13}$, espécie de comandante militar na defesa do reino, em 1363.

O sucessor do trono, D. Fernando, levaria ao revés a paz alcançada durante o reinado de seu pai, D. Pedro I. Assim que é coroado, em 1367, o soberano candidata-se ao trono de Castela como neto legítimo de Sancho IV, contra Henrique II (Henrique de Trastámara), assassino de seu meioirmão, Pedro I de Castela. Entre períodos de guerra e trégua com o vizinho, os portugueses se veem em situação delicada. Outra polêmica advém do casamento de D. Fernando, em 1372, com Leonor Teles de Menezes, mulher ainda casada, em processo de separação, e representante da Nobreza latifundiária, cuja figura não é bem aceita pela população.

Não obstante, o monarca toma parte na Guerra dos Cem Anos, disputa entre França e Inglaterra pela sucessão do poder, porém sua participação é marcada por constantes alterações de alianças, associadas ao Grande Cisma do Ocidente, que lhe rendem descrédito, invasões e

\footnotetext{
${ }^{12}$ A Ordem Militar de Avis é a mais antiga das Ordens Portuguesas e ocupa um singular espaço na História de Portugal, por ter dado o nome à segunda Dinastia. A actual Ordem tem origem na antiga Ordem Militar de S. Bento de Aviz, cuja fundação está envolta em lendas, que pretendem essencialmente demonstrar uma maior antiguidade que a da Ordem Militar de Calatrava, a cuja observância se cingiu a partir do final do século XIII. No decreto de restabelecimento da Ordem, em 1917, faz-se referência à origem lendária da Ordem, referindo-a como "a mais antiga ordem militar de Portugal, criada por D. Afonso Henriques em 13 de Agosto de 1162" (MELO, Olímpio de; Ordens Militares Portuguesas e outras Condecorações, Imprensa Nacional, Lisboa, 1922, p. 41). Esta versão, que já constava do Alvará com que o Rei D. Carlos reformou da Ordem em 1894, é posta em causa pela falta de documentação coeva que a sustente. Disponível em www.ordens.presidencia.pt/?idc=179. Acesso em: 25 jan. 2015.

${ }^{13}$ A antiga Ordem de Avis terá antes tido origem numa confraria de cavaleiros criada por, ou sob a protecção de D. Afonso Henriques, em data posterior à conquista de Évora (1166), por Geraldo, o «Sem-Pavor». A Milícia de Évora, como era conhecida, terá sido fundada por volta de 1175 , tendo por finalidade assegurar a defesa da cidade contra os mouros. Estava submetida à regra beneditina, pelo que o nome de $\mathrm{S}$. Bento ficaria, de futuro, associado ao nome da Ordem. O primeiro Mestre parece ter sido D. Pedro Afonso, filho ilegítimo de D. Afonso Henriques. Em 1187, a Milícia submeteu-se à obediência da ordem castelhana de Calatrava, tendo assim passado a ser conhecida como Milícia de Évora da Ordem de Calatrava até que, por volta de 1223, os freires de Évora se mudaram para Avis. O nome de Avis é, desta forma, posterior à fundação da Ordem e durante anos coincidiu com a obediência à ordem castelhana. Foi no reinado de D. Dinis que a Ordem de Avis começou a ganhar autonomia face a Calatrava e o momento fundamental na história da Ordem está na designação de D. João, filho ilegítimo do Rei D. Pedro I, como Mestre de Avis. A morte do Rei D. Fernando I e a crise de 1383-1385, acabou por ditar a subida ao trono do Mestre de Avis e o início da dinastia do mesmo nome. Disponível em www.ordens.presidencia.pt/?idc=179. Acesso em: 25 jan. 2015.
} 
descontentamentos cada vez maiores por parte dos mercadores e classes baixas de seu país. Inúmeras querelas infrutíferas têm por consequência o fim da dinastia de Borgonha, que cederá lugar, após a Revolução de Avis, à linhagem de mesmo nome.

Com a morte de D. Fernando, em 1383, a falta de herdeiro masculino exigia que a rainha mãe, D. Leonor, governasse até que sua única filha legítima, D. Beatriz, casada com o rei D. João de Castela, tivesse um herdeiro e que esse pudesse reinar. As cláusulas testamentárias visavam a garantir a separação permanente dos dois reinos.

Nesse interim, D. João I de Castela, rei do país vizinho, apresenta-se como candidato à Coroa, alcançando certo prestígio entre as altas classes da Nobreza, cuja situação econômica não lhes era favorável. No entanto, o repúdio à perda da independência faz com que a burguesia comercial marítima se alie a D. João, mestre de Avis, irmão bastardo de D. Fernando. O assassinato de Andeiro, amante da rainha, resulta na fuga de D. Leonor e pedido de auxílio ao genro D. João de Castela, que invade Portugal. Tal investida é compreendida pelos portugueses como afronta à autonomia lusitana, o que resulta em adesões massivas à causa pelo flanco do Mestre de Avis.

Após meses de resistência, um surto de peste assola os castelhanos e resulta na retirada das tropas. Na cidade de Coimbra, no ano de 1385, D. João é nomeado rei D. João I. Reagindo ao decreto, as tropas castelhanas invadem mais uma vez Portugal, mas são expulsas. A paz se consolida apenas em 1411, após a assinatura de um acordo. Inicia-se o reinado da dinastia de Avis, em cujo governo Portugal se tornaria o centro do mundo e, posteriormente, assistiria a seu passado glorioso entrar em declínio.

\subsubsection{Dinastia de Avis: glória e declínio}

Logo que recebe o título de soberano, D. João I trata de fortalecer suas bases de sustentação no governo, com o intuito de evitar desuniões ou golpes que pudessem lhe custar a Coroa. Para tanto, retribui generosamente àqueles que lutaram a seu lado, concedendo-lhes títulos e posições de prestígio na administração pública. Dentre esses homens renomados, destaca-se Nuno Álvares Pereira, herói de guerra e representante significativo da nova e forte aristocracia, detentora de terras, que se ergue juntamente com o monarca.

Diante da perspectiva de adquirir credibilidade e apoio político, D. João I casa-se com a princesa inglesa Filipa de Lancaster, e do matrimônio vem herdeiros que alcançariam papel de destaque na história lusitana dos descobrimentos. Camões refere-se, em Os Lusíadas, aos filhos de D. João I e Filipa de Lancaster pelo título de Ínclita Geração. 
Outra medida adotada para fortalecer o poder real e diminuir possíveis disputas são as generosas doações e atribuição de títulos a seus herdeiros legítimos. D. João (condestável de Portugal) é nomeado administrador da ordem de Santiago, D. Fernando (Infante Santo), mestre de Avis, D. Pedro (Cavaleiro das sete partidas), duque de Coimbra e D. Henrique (O navegador), duque de Viseu, recebe também a administração geral da ordem de Cristo, uma das mais ricas da época.

O reinado do antigo mestre de Avis é marcado pela organização de expedições militares à África. Com tais ofensivas, obtém a adesão da Nobreza, ainda defensora do ideal das Cruzadas, e o alívio da pressão política por conta da crise econômica, desviando as atenções para outro foco. A conquista de Ceuta, no ano de 1415, confere ares de concretude à nova imagem expansionista, que Portugal aos poucos ergue a seu redor.

O herdeiro direto do trono, D. Duarte, desde jovem participa do governo paterno. Com a morte do rei, em 1433, adere ao impulso da guerra expansionista. Destaca-se o ataque a Tânger, em 1437, quando o infante D. Fernando, mestre de Avis, morre como refém em terras inimigas. D. Duarte falece em 1438, e, em virtude da menoridade de seu filho, o governo é assumido por Leonor de Aragão (rainha viúva), apoiada por D. Henrique e D. Afonso de Barcelos (genro de Nuno Álvares e irmão bastardo de D. Duarte). Porém, essa decisão encontra resistência por parte de D. Pedro, duque de Coimbra, e de seu irmão, D. João. Após curto período de guerra civil e concessão do título de duque de Bragança a D. João, D. Pedro governa como regente entre os anos de 1441 e 1448.

Logo que atinge a maioridade, o filho de D. Duarte, D. Afonso V, assume o poder, dispensa os serviços do tio D. Pedro e toma por conselheiro o tio Afonso de Barcelos de Bragança. De acordo com Joaquim Veríssimo Serrão, o reinado de D. Afonso V tem por características:

\footnotetext{
$\mathrm{Na}$ política de expansão ultramarina, como se verá, importa ter em conta o descobrimento das terras que vão do rio do Ouro ao cabo de Santa Catarina; (...) Na política interna, contrariando as medidas de centralização do infante D. Pedro, tornou-se $\mathrm{D}$. Afonso $\mathrm{V}$ bastante pródigo em doações à alta nobreza, que permitiram o engrandecimento de várias casas senhoriais. (...) Na política externa salientam-se o fracasso das suas relações com Castela, o insucesso da aliança que contraiu em França e, em virtude da perseguição movida aos familiares e adeptos do infante D. Pedro, o afrouxamento dos laços que o prendiam à corte de Borgonha (...) (1996, p. $101)$.
}

Seu reinado marca a última fase de Portugal feudal, caracterizando-se pelo fortalecimento das casas nobres e pela política sistemática de conquistas em Marrocos, especialmente por meio de alianças com o papado e organização de cruzadas católicas. 
Nascido em Lisboa, ao ano de 1455, o herdeiro do trono, D. João II, chega ao poder em 1481, com o objetivo de dar fim aos abusos que o pai cometera em favor da classe aristocrática. No entanto, sua política de cortes não é vista com simpatia pelos nobres, que são diretamente afetados pelas medidas. Conspirações levantam-se como resposta à postura centralizadora do soberano, porém são combatidas com veemência, o que se verifica, por exemplo, pela decapitação na praça pública de Évora do líder da resistência, D. Fernando II, terceiro duque de Bragança, mais poderoso aristocrata da época. Como resultado, D. João II alcançaria em seu reinado o fortalecimento do poder real, o aumento das reservas da Coroa, especialmente com o confisco dos bens da casa ducal de Bragança e a criação da política ultramarina, por meio da qual Portugal alcançaria posição de prestígio no mundo.

Em consequência da autoridade que assume e evidencia a outros reinos, Portugal passa a ser visto por muitos como um reino pacífico, em oposição a Castela, que passa por constantes crises sucessórias. Em função disso, um grande número de judeus oferece a D. João II vultosa quantia para que pudessem ser admitidos no país. O rei permite-lhes a entrada, porém, para não causar protestos internos, restringe a permanência dos judeus por oito meses no país, ao fim dos quais deveriam retirar-se. Terminado o prazo, algumas famílias judias abastadas já estavam em posse de visto de residência permanente. Aos demais, caberia prisão ou expulsão. O impasse no trato com os judeus é uma constante nos reinados subsequentes.

Como seus antecessores, o monarca sonhava em associar sob a égide lusitana os reinos de Castela e Portugal, alcançando, assim, a União da Península Ibérica. Para tanto, tenciona unir em matrimônio seu herdeiro, D. Afonso, e D. Isabel de Castela, filha dos reis católicos Fernando e Isabel. No entanto, o consórcio não é bem sucedido, visto que o príncipe falece pouco tempo após o casamento, sem deixar descendentes. Ainda no ano de 1490, o monarca dá indícios de fraqueza, ao que são atribuídas duas razões: a progressão de uma doença crônica no fígado ou o envenenamento mal sucedido, que lhe teria desencadeado complicações que o levariam à morte. Atribui-se à rainha, D. Leonor de Viseu, a autoria do atentado, como forma de vingança contra o monarca, que, em anos anteriores, sentenciou a morte, por tomar parte em uma conspiração, o duque de Viseu, D. Diogo, irmão da rainha. Com a morte de D. João II e sem a existência de herdeiros diretos, a Coroa vai para as mãos de D. Manuel, irmão mais novo da rainha viúva. O maior legado do Príncipe Perfeito, como ficou conhecido D. João II, são as descobertas marítimas, levadas a cabo com afinco pelo monarca.

Assumindo a Coroa com o codinome $O$ Venturoso, por ser o oitavo na linha de sucessão de D. João II, D. Manuel I dá continuidade à empreitada marítima portuguesa, vindo a governar o império "onde o sol nunca se põe". Porém, cabe-lhe a responsabilidade de equilibrar a liberdade, 
consequente crescimento do poder da aristocracia, durante o complacente governo de D. Afonso V e a ferocidade de seu antecessor, D. João II, que reduzira a custos altos a influência da Nobreza no governo português absolutista. Ele, como condição matrimonial para desposar D. Isabel de Castela, em mais uma das inúmeras tentativas de unir os reinos, tem que solucionar um problema deixado por seu antecessor: a questão dos judeus. D. João II aceitara vultosas somas para permitir a entrada de judeus, os quais viam no país a possibilidade de não serem perseguidos como em outras nações. Liberado o ingresso, os judeus deveriam, após oito meses, deixar o país, ou seriam expulsos. Ao fim do período estipulado, muitos abandonam o país, porém os mais abastados já contavam com licenças de permanência caríssimas concedidas pelo rei.

Como condição para o casamento, os reis Fernando e Isabel impõem a expulsão definitiva dos judeus do reino que D. Manuel I governa. O monarca recorre à diplomacia e, por manobra política, submete os judeus à "conversão" massiva, originando-se, então, o termo cristãos-novos para designá-los. Mantenedor do poder econômico fundamental para o país, na figura dos judeus, o rei casa-se com D. Isabel e tem seu primeiro filho, D. Miguel da Paz. O sonho de unificar as Coroas Ibéricas perde força quando falece sua primeira esposa e, logo depois, dois anos mais tarde, seu herdeiro.

O rei casa-se, então, com a cunhada, irmã de D. Isabel, D. Maria, com quem gera D. João III. Anos mais tarde, enviúva novamente, casando-se então com sua sobrinha, D. Leonor, prometida a seu filho. O episódio é retomado na primeira cena do texto teatral de Helder Costa, quando a personagem ficcional Camões apresenta El-Rei Seleuco, cujo enredo remete ao episódio ocorrido na Corte Manuelina anos antes.

Embora o reinado de D. Manuel seja marcado por certa prosperidade, com a descoberta e conquista de novos territórios, o monarca se depara com despesas volumosas para a manutenção de colônias, além das perdas que se deram em função da restituição de bens às famílias nobres que haviam sido prejudicadas por seu cunhado, D. João II, especialmente os Braganças. Tais gastos evidenciam a crise econômica, que nos reinados seguintes será mais grave, acrescendo aspectos políticos e religiosos que legitimaram o declínio que culminaria no domínio espanhol, o que legaria ao pretérito a bonança lusitana.

O aparente equilíbrio alcançado no reinado manuelino não se estendeu ao de seu filho, D. João III, monarca que teve duas fases bastante distintas no poder. A primeira, na qual demonstra ser “(...) tolerante, aberto às correntes internacionais do pensamento, louvado por humanistas e sempre disposto a acolhê-los, o verdadeiro Mecenas (...)" (MARQUES, 1978, p. 300), que conduz às universidades portuguesas e, ao próprio palácio real, estudiosos que auxiliaram a recuperar o tempo perdido, em que o país se distanciara do restante da Europa. Em sua segunda fase, D. João III, dos 
anos finais de década de 1530 e anos iniciais de 1540, o monarca, após ver todos os nove filhos morrerem antes dos dezenove anos, somado à perda de cinco irmãos, transforma-se em fanático religioso, que atribui tais desgraças à heresia, personificada na figura dos cristãos-novos. Instala-se a Inquisição (1536) e, anos mais tarde, entram no país inúmeros jesuítas da Companhia de Jesus, o que paulatinamente transfere o poder real para o alto escalão dos tribunais inquisidores. Massivas quantidades de judeus e cristãos-novos abandonam o país em posse de seus bens, o que resulta no agravamento da crise econômica do reino, além de retrocesso e estagnação do desenvolvimento cultural, que começava a florescer.

Essa derrocada é o pano de fundo da peça de Helder Costa. Por meio da caracterização das personagens (o que elas dizem, o que fazem e o que se diz delas) combinada aos reveses por que passa a personagem ficcional Camões, desde a conturbada vida na corte até seu forçado embarque na expedição de Vasco da Gama, evento no qual o poeta experiencia o que eternizará em $O s$ Lusíadas, estabelecem-se diálogos com a lírica camoniana, além de alusões à instalação da Inquisição nos domínios do além-mar lusitano, compondo, assim, uma visão bastante crítica do que seria a sociedade portuguesa da Corte Joanina. D. João III, segundo a visão apresentada na peça, é a materialização do declínio português. Sucede-se a seu reinado uma regência, até que o Desejado atinja a maioridade. D. Sebastião, que, duas semanas antes de nascer, fica órfão de pai, o príncipe João de Portugal, torna-se rei aos três anos, porém ascende ao trono ao atingir catorze anos.

São formadas regências, que governam até que $O$ desejado atinja a maioridade, uma delas exercida por sua avó, D. Catarina, de 1557 a 1562, seguida pelo tio-avô do herdeiro, cardeal D. Henrique, entre 1562 e 1568. Ambos os governos são visivelmente envoltos pelo espírito religioso beato do antecessor. Nesse período, a educação ficou legada quase que integralmente aos jesuítas, ocorrendo frequentes tentativas portuguesas, com a contribuição do clero, de defender-se melhor da pirataria francesa e inglesa e construir fortalezas no norte da África, com a finalidade de manter as conquistas.

Segundo definição de Oliveira Marques, D. Sebastião é caracterizado como:

Enfermo no corpo e no espírito, importa-se pouco com o ofício da governação, perdido antes em sonhos de conquista e de expansão da fé. Conquistar Marrocos era a sua ambição número um, mas outros projectos de imperialismos em terras pagãs preenchiam-lhe a imaginação. Ousado até os limites da loucura, o rei não concedia lugar ao planejamento cuidadoso, à estratégia ou a retirada, igualando tudo isso a medo ou cobardia. (1978, p. 421). 
Na peça de Helder Costa, o rei é retratado como um boneco que não governa, mas deixa que falem por ele, no caso, os Irmãos Câmara, respectivamente confessor e conselheiro do monarca, que, na visão do dramaturgo, são os verdadeiros detentores do poder real.

O desatinado monarca, limitado por certo tempo em suas ambições pela escassez de recursos, passa a contrair empréstimos, solicitar o auxílio do tio, Felipe II, rei de Espanha, até finalmente associar-se a Mulay Muhammad al-Mutawakkil, que, destronado por Mulay 'Abd alMalik, espera retomar o poder. D. Sebastião desembarca em Arzila, onde, acompanhado por desorganizado exército e as forças de seu mais novo aliado, ruma para o sul de Alcácer Quibir, onde o nobre português é dizimado por um exército de cerca de mil infantes e quarenta e um mil cavaleiros.

Assume o trono, agora em definitivo, o cardeal D. Henrique, que, embora houvesse tentado manter a independência portuguesa, acabou por falecer em 1580, deixando caminho aberto ao mais forte dos possíveis sucessores: D. Filipe II de Espanha.

A peça de Helder Costa encerra-se no momento em que Portugal passa a integrar a União das Coroas Ibéricas, coincidentemente no mesmo ano em que Camões teria morrido. A esse episódio refere-se o último diálogo do texto teatral, proferido por Chiado, que exalta a "libertação" do autor, que não presenciou a derrocada de seu país.

Embora não esteja diretamente relacionada ao período no qual o dramaturgo português ambienta sua peça, faz-se relevante, ainda que breve, a citação dos eventos que se seguem na História Portuguesa até o momento em que o texto teatral de Helder Costa é produzido. Apenas entre os anos de 1638 a 1640 se inicia o movimento de Restauração da Autonomia Portuguesa: D. João IV reina a duras penas para manter assegurada a independência, segue o reinado de D. Pedro II, que destrona o irmão, D. Afonso VI. Surge então a figura de D. João V, que, aos moldes franceses, vive na opulência, sucedido por seu filho, D. José I, que entrega a administração do reino ao Marquês de Pombal, o qual tenta modernizar o país, mas é barrado pela rainha, D. Maria I.

Eclode a Revolução Francesa e a declaração de bloqueio continental àqueles que comercializavam com a Inglaterra. D. João VI é declarado rei após a constatação dos problemas mentais da rainha, refugiando-se, junto à Corte, em terras brasileiras. Portugal é invadido três vezes, sendo deixado em situação deplorável, gerando revoltas populares, que exigem o retorno do rei ao país. O Brasil é proclamado independente, o que ocasiona disputas de sucessão ao trono lusitano, entre D. Pedro e D. Miguel. Segue-se sanguinolenta guerra civil entre 1826 e 1827.

Vitorioso, D. Pedro é sucedido por D. Maria da Glória, que busca equilibrar os interesses das partes conflitantes, sem muito sucesso. D. Fernando, rei consorte, governa até que D. Luis assuma o trono. D. Carlos é seu herdeiro, porém, na época em que Portugal recebe o Ultimatum 
inglês. Em 1908, o rei e o herdeiro são assassinados, deixando perdurar a ditadura de João Franco, demitido, posteriormente, por D. Manuel II. Em 1910, proclama-se a República, a qual dura até 1928, visivelmente instável, especialmente após a Primeira Guerra Mundial. Em 1926, o general Gomes da Costa encabeça uma revolução que é vitoriosa, porém liderada por Oscar Carmona, que implanta uma ditadura. Oliveira Salazar é indicado para gerir assuntos relativos às finanças, e, aos poucos, consegue autonomia e controle dos gastos públicos. Em 1932 constitui-se o Estado Novo, bem aos moldes de outros governos totalitários, tais como a Alemanha, a Itália e a Espanha.

Salazar é ditador consagrado e, ao menor movimento de manifestações oposicionistas, enfatiza seu poder por meio da P.I.D.E (Polícia Internacional de Defesa do Estado). Marcelo Caetano assume o poder sob a tutela salazarista, sendo definitivamente retirado do governo quando, após sucessivas tentativas, depõe-se o Estado Novo, era 25 de abril de 1974 - Revolução dos Cravos. Portugal é então governado por uma Junta de Salvação Nacional, liderada por General Antônio Spinola e Costa Gomes. Seguem-se cinco governos provisórios, eleições são realizadas, porém permanecem as insatisfações e os conflitos pelo poder, remanescentes ainda por longo período.

O país que outrora fora o centro do mundo passa por duros golpes, como a perda de colônias africanas, a instabilidade financeira em face do gigantesco atraso tecnológico e administrativo em relação ao restante da Europa, além da dependência da produtividade agrícola e da produção de matéria-prima, que, ainda hoje, desequilibram sua balança comercial.

\subsection{Navegar é preciso}

Ao fazer referência às expansões marítimas ocorridas entre os séculos XV e XVI, na Europa, não se pode deixar de mencionar que esse momento histórico contou com diversas etapas e motivações. No caso da participação lusa, cabe ressaltar que houve constantes mudanças na força motriz que impulsionou o processo, de acordo com as figuras que o lideravam. $\mathrm{O}$ historiador Joaquim Serrão adverte a respeito do tratamento superficial que eventualmente possa advir do fato de se considerar as descobertas marítimas como fruto de um ou de outro aspecto isoladamente.

O encontro de 'novos mundos' não pode haver-se como obra do acaso, nem somente movido pela indagação do desconhecido, porque correspondeu a uma exigência colectiva a que deram força a própria natureza actuante e reais imperativos de sobrevivência. (...) Tal facto comprova que a orgânica dos Descobrimentos se foi alterando no seu ritmo de acção, buscando novas realizações à luz da experiência colhida e numa ordem causal diferente. Haverá, pois, que distinguir entre os impulso [sic] que conduziram às viagens no tempo de D. João I 
e as razões que foram dando um rumo próprio à exploração da costa ocidental africana quando da morte do infante D. Henrique ou da realeza de D. João II. O processo estendeu-se ao longo de quase oitenta anos, com a variação permanente ou alternada do seu motor histórico. (...) Costuma ainda focar-se a Expansão nos aspectos espiritual e económico, como se houvesse sido apenas movida pela difusão do ideal religioso ou pela busca do proveito material. A problemática é mais complexa e não cabe no esquema simplista de situar a predominância de um desses factores ou de se proceder à sua junção. Mergulha mais fundo, no tempo e no espaço, a radicação dos Descobrimentos, que foi também de ordem geográfica, política, sociológica e cultural, sendo a sua origem anterior à história portuguesa do tempo. (1996, p. 119-20).

Os descobrimentos podem ser compreendidos como uma moeda cujas faces opostas convivem entre si, criando uma unidade. Ao levar em conta os fatores que serviram de mola propulsora aos descobrimentos em geral, deve-se considerar: a ascensão burguesa, em detrimento da Nobreza feudal, já bastante enfraquecida com a consolidação das bases capitalistas de organização social; a centralização monárquica; a prática do mercantilismo e a cisão da Cristandade. Por outro lado, as bases ideológicas que estruturavam a sociedade eram ainda fortemente teocêntricas, o que gerava temeridade sem precedentes quanto aos desbravamentos marítimos, especialmente porque, em teoria, o homem estaria desafiando a natureza e, consequentemente, Deus. Além disso, havia os agravantes relacionados à viagem, dentre eles a crença de que a Terra era quadrada, o que resultaria em "queda", caso o navio alcançasse o horizonte, ou mesmo fantasiosas lendas de monstros e criaturas horrendas que habitavam os mares.

Portugal foi o pioneiro a lançar-se aos mares porque conjugou uma série de elementos favoráveis e necessidades internas que assim o impeliram. Data-se de 1415, a partir da conquista de Ceuta, o início oficial dos descobrimentos, que se prolongam até 1543, quando os primeiros portugueses chegam ao Japão. Conforme afirmado anteriormente, o território lusitano constituiu-se prematuramente como Nação independente desde o ano de 1179, sob o reinado de Afonso Henriques, então Afonso I de Portugal, da dinastia de Borgonha. A este respeito, Serrão afirma:

Numa época em que os países da Europa ocidental estavam ainda longe de sua definição nacional, já o nosso país detinha uma força política que tornava possível a extroversão marítima. A paz com Castela, assinada em 1411 embora apenas ratificada vinte anos mais tarde, logo garantiu as condições de acção militar para o Reino sair do estreito limite das suas fronteiras. (1996, p. 122).

Além da centralização política prematura, deve-se considerar que a posição geográfica portuguesa foi um fator decisivo para a empreitada marítima. De acordo com Luiz Geraldo Silva, os portugueses não se configuravam essencialmente como uma nação marítima, mas sim como “(...) 
resultado natural de uma dada situação política e geográfica, na qual um povo inteiro vivia espremido entre a terra dominada pelos castelhanos e o Atlântico, não tendo, portanto, outros horizontes para se expandir.” (2001, p. 23).

Pressionado entre a Espanha, vizinha com a qual se estabeleciam relações instáveis, e o desconhecido Atlântico, o mar passou a ser a alternativa mais imediata na expansão do pequeno país. Há registros de expedições marítimas com finalidade de reconhecimento desde o reinado de D. Dinis, a quem o poeta Fernando Pessoa atribui o título de visionário, uma vez que o monarca plantou os pinheiros de Leiria com o objetivo de conter os avanços naturais do mar, porém teria deixado às gerações futuras a madeira com a qual as caravelas foram construídas.

Somem-se aos fatores citados os custos elevados para aquisição de especiarias originárias da Índia, cuja distribuição na Europa passava pelos mulçumanos, que as obtinham em seu lugar de origem, transportavam-nas até o Mediterrâneo e vendiam-nas aos comerciantes italianos, especialmente da região de Gênova e Veneza, que, por sua vez, revendiam as mercadorias a preços exorbitantes. Ciclo parecido de negociação tinha o ouro, porém comercializado por povos africanos, que conheciam sua localização. $\mathrm{O}$ acesso a esses produtos sem intermediários poderia garantir a Portugal uma alternativa definitiva para os problemas financeiros que assolavam o país. O patrimônio da Coroa estava, em grande medida, nas mãos da aristocracia, especialmente aquela que fora generosamente compensada por monarcas como D. João I, D. Duarte e, mais tardiamente, D. Manuel e D. João III. A manutenção da paz, ou a ausência de conflitos diretos, rendia onerosos custos que dilapidavam, ainda mais, as reservas da Coroa. Outro fator importante para as navegações foram os avanços tecnológicos, que permitiram a construção de navios seguros para viagens em mar aberto. Destaque-se a invenção do leme central para comandar o navio, a bússola, o astrolábio e o quadrante, que auxiliavam na localização da rota a ser seguida. O desenvolvimento da Cartografia desempenhou papel crucial no acesso e na ampliação de dados que favorecessem os objetivos das expedições.

Conforme Luiz Geraldo Silva:

(...) do ponto de vista cultural, a ascensão dos homens do mar no contexto do Renascimento apoiou-se na articulação de dadas tradições, que pareciam ter pelo menos quatro fontes básicas: o saber-fazer medieval ligado às lides marítimas, o saber erudito, particularmente geográfico, vindo dos antigos, o próprio cristianismo e as muitas concepções fantásticas advindas de toda parte.

Em primeiro lugar, o saber tradicional medieval quanto à navegação marítima baseava-se no conhecimento adquirido em duas vastas áreas da Europa: O Norte, onde a navegação já há séculos iniciada pelos povos escandinavos, em decorrência de uma plataforma continental muito ampla, tinha como referência maior para determinação de rumo a ajuda de sondas e o conhecimento das marés; e o Mediterrâneo, onde os métodos de determinação de rumos de navegação eram bem 
mais avançados. Ao longo de toda a época medieval, a utilização de portulanos antigas cartas de navegação - e o emprego generalizado da agulha imantada, já instalada sobre a rosa dos ventos, por exemplo, constituíam a base da navegação no mare nostrum dos romanos.

Por sua vez, o saber erudito vindo da antigüidade dera ao homem do mar do Renascimento, ou pelo menos os mais poderosos dentre eles, argumentos que the permitiram pleitear favores às monarquias então ascendente e aos grandes financistas para empreender sua venturas aparentemente tresloucadas. Nesta direção, como sugere Jean Delumeau, à medida que se conheceram melhor os trabalhos e as concepções geográficas dos gregos, as viagens marítimas do Renascimento foram amplamente favorecidas.

Os gregos, desde a escola pitagórica, e depois com Aristóteles, já não nutriam dúvidas quanto à esfericidade da Terra. Contudo, boa parte da Idade Média acreditava, pelo contrário, que a Terra era achatada. Poucas eram as vozes dissonantes: Alberto Magno (1200-1280) e Roger Bacon (1214-1294) eram duas delas. Eratóstenes (276-194 a. C.), por sua vez, muitos anos antes, dera uma medida notavelmente exata do perímetro do Equador $(39.690 \mathrm{Km})$, mas, no renascimento, os homens do mar preferiam acreditar em Ptolomeu (127-160), cujos cálculos da circunferência terrestre estavam redondamente errados: segundo eles, a Terra não ia além dos $28.350 \mathrm{Km}$. Todavia, foi esse erro fecundo que deu a Colombo a coragem para empreender a grande viagem para o Oeste. Desconhecido por quase todo o medievo, e longe de ter sido um total estorvo para o homem do Renascimento, Ptolomeu teve sua geografia traduzida para o Latim graças às pesquisas de humanistas entre 1406 e 1410.

Em terceiro lugar, é fato que, para os navegadores dos séculos XV e XVI, o cristianismo tinha, por um lado, o papel de servir de fonte de inspiração e motivação para a elaboração e seus projetos, mas por outro lado, na visão de mundo dos navegadores, segundo o espírito contraditório do Renascimento, as concepções cristãs constituíam muitas vezes crenças inabaláveis e até certo ponto anacrônicas para a época. Colombo, por exemplo, partiu para a Índia em direção ao Ocidente sonhando com a conquista de Jerusalém; mas ainda tinha como certo, como leitor de Marco Polo, que encontraria o Grande Khan, de modo a convertê-lo ao cristianismo.

(...) Por último, e em quarto lugar, fantasias estavam por toda parte nos incertos mapas do mundo daqueles tempos e nos conhecimentos disponíveis acerca da Terra. Muitas dessas fantasias vinham da Antigüidade, tais como as coleções de lendas e as curiosas descrições de animais estranhos e homens monstruosos alimentadas por marujos gregos. O Oriente extremo era o palco por excelência dessas visões fantásticas, e a Índia, particularmente, oferecia imagens da luta de pigmeus contra grous e de gigantes contra grifos. O cristianismo fornecera igualmente bases fecundas ao terreno do maravilhoso. Jerusalém, por exemplo, situava-se precisamente no meio do mundo - idéia partilhada por Colombo, por exemplo - , bem como localizava-se na Ásia o paraíso terrestre, de onde provinham os quatro maiores rios do mundo - o Fison, o Gion, o Heidequel e o Eufrates. (SILVA, 2001, p. 17-9).

As empreitadas marítimas eram a promessa de solução eficaz e definitiva dos problemas financeiros portugueses, uma vez que representavam: à Coroa, maior poder e impostos; aos burgueses, o lucro do comércio; aos nobres, prestígio e posição social; ao cidadão comum, a promessa de riqueza fácil. Com o tempo, até mesmo a Igreja passou a compartilhar dos ideais expansionistas, uma vez que poderia espalhar sua fé e garantir, com isso, maiores bens e doações. 
No entanto, cabe ressaltar que as expedições marítimas não eram vistas por todos como uma "tábua de salvação", posto que implicavam inevitáveis perdas de vidas e investimentos exorbitantes, que comprometiam consideravelmente o país. Tais queixas encontram espaço na voz da personagem do Velho do Restelo, n'Os Lusíadas, de Camões.

Com o intuito de elucidar a relevância das expedições marítimas à História Portuguesa, segue breve menção acerca das principais conquistas durante esse período. Embora não haja comprovação irrefutável da primazia lusitana, acredita-se que, em 1374, durante o reinado de Afonso IV, teria ocorrido a viagem às Ilhas Canárias, que, por meio de tratados posteriores, passaram a ser domínio de Castela. A primeira façanha portuguesa de mesma ordem teria ocorrido em 1415, com a conquista de Ceuta, durante o reinado de D. João I, mestre de Avis. Entre os anos de 1417 e 1420, sob as ordens do infante D. Henrique, ter-se-ia alcançado o arquipélago da Madeira, localizado na região sudoeste da costa portuguesa. Ali se desenvolvia a cultura da cana e, mais tardiamente, do vinho. Seguiu-se à chegada ao arquipélago de Açores, em 1427, a passagem pelo Cabo Bojador, com o navegador Gil Eanes (1434). A Afonso Gonçalves Baldaia coube, em 1438, chegar a Angra dos Ruivos e Rio do Ouro. A derrota em Tânger, no ano de 1437, conforme mencionado anteriormente, resultou na morte de D. Fernando, Infante Santo, adiando a conquista do Norte africano. Durante o reinado de D. Afonso V, Tristão Nunes alcançou o Cabo Branco, em 1441, seguido por Diogo Gomes, em 1456, com a descoberta de Cabo Verde. Em 1460, mesmo ano da morte do infante D. Henrique, os portugueses já estendiam seus domínios até Serra Leoa.

Em virtude de interesses financeiros, o soberano D. Afonso V concede, no ano de 1469, o monopólio do comércio marítimo da região costeira da África a Fernão Gomes, que, em contrapartida, tem que dar continuidade às explorações na costa africana. Os esforços portugueses se voltam mais uma vez para a região do Marrocos, mais especificamente para Alcácer Ceguer (1458) e Arzila (1471). Em cumprimento ao que havia sido acordado, Fernão Gomes contou com a ajuda de navegadores, cuja experiência garantiu o sucesso da empresa. Em 1474, quando seu contrato com a Coroa expirava, as descobertas portuguesas já incluíam o Cabo de Santa Catarina, a Ilha Formosa, Terra Nova e Cabo Lopo Gonçalves (hoje conhecido por Cabo Lopez).

Nas mãos de D. João II, as campanhas marítimas tornaram-se a principal renda da Coroa. As expedições de Diogo do Cão tiveram por objetivo alcançar o Oceano Índico, o que significou assegurar caminho por mar que levasse às Índias. Acreditou-se ter chegado ao fim do continente africano (oceano Índico) quando atingiu a foz do Rio Zaire (1482), porém a conclusão provou-se errônea após alguns anos. Coube a Bartolomeu Dias, em 1488, dobrar o Cabo da Boa Esperança, primeiramente chamado de Cabo das Tormentas, em virtude da dificuldade em atravessá-lo. Luís de 
Camões e Fernando Pessoa eternizaram em seus escritos a relevância e significação controversa acerca desse marco das conquistas lusitanas.

Na peça de Helder Costa, o gigante Adamastor, assim como é representado n'Os Lusíadas, é personificado como um obstáculo às aspirações dos portugueses em chegar às Índias. Uma espécie de mitologia do "obstáculo natural" imposto às expedições. Em A Viagem - Camões - Poeta prático, há claras demonstrações por parte das personagens, que, ao acreditarem que estão próximas à morte, durante o confronto com a personagem do gigante, confessam pecados e assumem-se indignas de "espalhar a fé católica", visto que não viviam de acordo com a fé que pregavam. Estabelece-se a oposição entre o ser e o parecer, reforçando assim a ideia de que a missão evangelizadora dos portugueses não tinha apenas aspectos nobres, mas mascarava a premissa da ganância dos homens que ali se encontravam.

O objetivo de D. João II foi garantir e expandir os domínios portugueses nas rotas comerciais, especialmente por meio de acordos que protegessem os interesses da Coroa, tais como o Tratado de Alcáçovas e o Tratado de Tordesilhas, cuja promulgação só ocorre no reinado seguinte. O monarca almeja elevar Portugal ao status de Império, porém sua morte, em 1495, lega ao seu sucessor, D. Manuel, o prosseguimento de tal intento.

\subsection{Novas concepções estéticas e filosóficas}

Emprega-se o termo Renascimento para se referir a todo um processo de transformações sociais, políticas e econômicas entre os séculos XIV e XVI, que modificaram radicalmente o mundo até então conhecido. Dentre as transformações, as expedições ultramarinas figuram entre as mais relevantes. Porém, cabe ressaltar que a força dos renascentistas se deveu, em grande medida, ao movimento cultural humanista.

O Humanismo teve suas primeiras aparições em Florença, no século XIV, tornando-se um dos centros irradiadores dessa corrente de pensamento para o restante da Europa. O termo é inspirado no conceito de humanitas - pertencente à humanidade - que se refere às potencialidades humanas de desenvolvimento da razão, especialmente a partir do resgate de clássicos greco-latinos, como Platão, Aristóteles e Ovídio, a fim de depurarem-se e depreenderem-se novos métodos históricos e filosóficos que recuperassem a concepção dos antigos, tornando-se esse um período de erudição formalista, com o objetivo de fortalecer novas formas de compreensão do mundo.

No que tangia à Escolástica, os humanistas questionavam os métodos de ensino, ainda bastante calcados na justificativa dos dogmas da Igreja Católica. A releitura de filósofos conhecidos apenas pelo prisma escolástico ganhou especial atenção dos intelectuais da época. Destaca-se 
Erasmo de Roterdã, um dos mais influentes nesse campo, especialmente por sua abordagem conciliadora, que visava à manutenção da fé nas Escrituras, porém estimulava novas interpretações bíblicas, a partir do emprego da razão, o que serviu de base à Reforma Protestante, ocorrida anos mais tarde.

No campo social, os humanistas acreditavam que os governantes deveriam ser escolhidos pelo saber e por sua capacidade, desprezando, assim, aspectos bélicos. Contudo, a Contrarreforma, caracterizada por medidas violentas, que visavam à manutenção das instituições, especialmente a Igreja Católica, evidenciavam o caráter frágil dos discursos humanistas, pois, embora houvesse críticas racionais, não havia respostas satisfatórias para que mudanças reais ocorressem.

Convencionou-se designar Renascimento o momento histórico-cultural de transição dos ideais medievos para a Idade Moderna, especialmente por meio da consolidação da figura humana como medida de todas as coisas.

O termo Renascimento foi cunhado pelos italianos Quatrocentistas, referindo-se ao renascer da cultura antiga como fonte de novos métodos de mundividência que pudessem ser aplicados àquele momento de transformações. No caso português, embora tenha ocorrido a centralização política prematura, a influência religiosa não se viu diminuída em função disso. Prova fulcral da mentalidade feudal teocêntrica portuguesa está no estabelecimento da Inquisição em pleno século XVI, a pedido do rei D. João III, contrariando os contínuos investimentos realizados pelo mesmo monarca na tentativa de trazer a Portugal a mentalidade humanista, representada por estudiosos vindos de toda a Europa para lecionar no país. Outros fatores como a descoberta da tipografia, as expedições marítimas e as descobertas científicas aceleraram ainda mais a busca por uma cultura que satisfizesse as novas aspirações da época.

No entanto, não se pode considerar que tenha existido um Renascimento, no sentido unívoco do termo, que corresponda às transformações ocorridas na Europa como um todo. Nesse sentido, pode-se aludir a Renascimentos, em sentido plural, a fim de se referir às mudanças, considerando as peculiaridades e idiossincrasias de cada país em que ocorreram.

O Renascimento foi gestado por diferentes fatores históricos que lhe conferiram a força com que se apresentou, conforme explica o professor Francisco Maciel Silveira, em Poesia Clássica:

É consabido que a transição da Idade Média para o Mundo Moderno se processou graças ao contributo de fatores sócio-político-econômicos. A ascensão da burguesia, a centralização monárquica dos Estados, a cisão da Cristandade, que vinha unificada sob a égide do Catolicismo e a autoridade papal, o mercantilismo convulsionaram a Europa, substituindo a hegemonia da Igreja, o teocentrismo, o sistema corporativo de comércio e a incipiente indústria manufatureira - bases em que se sustentava o universo medieval. (1988, p. 9). 
As descobertas, não apenas portuguesas, alavancaram de modo efetivo o capitalismo mercantil (mercantilismo), que se constituiu na busca de metais preciosos e de mercadorias de valor (inclusive escravos), que pudessem render lucros para quem os comercializasse. O elevado número de trocas no período evidencia a decadência daqueles que viviam das relações de comodato (trabalho em troca de proteção ou abrigo), especialmente a Nobreza feudal. Os constantes investimentos da Coroa na adoção da nova política econômica resultaram na mobilização de meios financeiros para viabilizar tais transações. Em consequência da inédita situação que se desenhava, ganhou força a figura do comerciante, burguês, que, tardiamente, buscará representatividade nos espaços administrativos.

No que se refere aos portugueses, há peculiaridades que merecem atenção. A burguesia lusitana, quase inteiramente, descendia de judeus (cristãos-novos, convertidos por manobra política de D. Manuel em 1496, com a finalidade de assegurar a permanência da classe abastada no país). Embora a burguesia tenha exercido papel fundamental de apoio à ascensão de D. João I ao trono, isso não significou o favorecimento dessa classe social durante seu reinado. Ao contrário, o monarca destinava os lucros obtidos com as conquistas aos nobres senhores feudais, a fim de garantir lealdade e apoio ao seu reinado (como ocorreu com Nuno Álvares Pereira, fundador de uma das casas mais poderosas de Portugal, Bragança). Tal concentração financeira nas mãos da Nobreza, em geral com mentalidade feudal, impediu que se fizessem investimentos na agricultura e indústria interna do país, o que gerou as crises econômicas durante o governo de D. João III. A promulgação da Inquisição durante seu reinado viria a sinalizar nova tentativa de centralizar o poder, por meio da doutrina católica que dominava o país, além de legitimar o confisco de bens dos hereges, em especial dos cristãos-novos, cuja riqueza teria por destino refazer as reservas financeiras da dispendiosa Coroa. Com a presença do Santo Ofício em Portugal, a maior parte dos comerciantes judeus abandonou o país. Tal migração populacional e financeira agravou, ainda mais, a situação portuguesa. A crise sucessória, após a batalha de Alcácer Quibir, veio consolidar a temida União das Coroas Ibéricas, porém a pequena burguesia que se manteve no país não estagnou seu desenvolvimento, desafiando de modo crescente o Estado e a Nobreza.

No que tange ao ideal teocêntrico, predominante na Idade Média, e sua maior representante, a Igreja Católica, cabe sinalizar algumas considerações. A centralização política monárquica, preconizada por Portugal e expandida por toda a Europa, inflige ao Clero a postura conciliadora de interesses, uma vez que a Igreja não é mais a única figura de poder representativa daquela sociedade. A Escolástica, pedra base do ensino religioso medieval, sofre abalo considerável com o movimento de racionalização e experimentação, que passa a nortear os estudos, inclusive de 
assuntos até então "inexplicáveis", que não por bases religiosas. Golpe ainda maior se dará por meio da Reforma, iniciada com Lutero e expandida por Calvino, fazendo emergir ideologias favoráveis à classe burguesa, além de reduzir o monopólio católico da interpretação da Bíblia e da intermediação com Deus, por meio da figura papal. A resposta Católica, anos depois, se dará por meio da Contrarreforma e, mais tardiamente, por meio dos Tribunais do Santo Ofício.

O Renascimento, especialmente o italiano, se opõe de maneira inconteste à Idade Média. No entanto: "Nota-se, em verdade, que uma das características da mentalidade renascentista consiste na conciliação do pensamento greco-latino com a doutrina cristã.” (SILVEIRA, 1988, p. 12). Isto é válido especialmente para países como Portugal e Espanha, onde se experimentava uma espécie de Renascimento, com tendências medievais. A este respeito:

(...) quando se fala em Renascimento, não podemos pensar num total divórcio com a Idade Média. A rigor, o Renascimento é um momento de transição do mundo feudal para a Idade Moderna. É um eco do passado e um arauto do futuro. Convém não esquecer que suas raízes estão na Antigüidade greco-latina, mas também na Idade Média. Se negligenciarmos este dado, não haveremos de entender como a Reforma e a Contra-Reforma, gestadas no ventre do Renascimento, empreendem um retrocesso à Teologia medieval e trazem novamente à tona a preocupação com o transcendente ou a revivescência do teocentrismo. Ou não compreenderemos como a centralização monárquica e o mercantilismo dos reinos português e espanhol constituem, no fundo, um neo-feudalismo estatal, pois o monarca, transformado em único suserano, detém a maioria dos bens mobiliários e fundiários no País e no Ultramar, monopolizando-os para dividi-los entre a nobreza ou explorá-los sem esquecer a cobrança de taxas senhoriais. (SILVEIRA, 1988, p. 13).

Porém, cabe salientar que o resgate dos clássicos não fez desaparecer as influências medievais dos dez séculos anteriores. O que se observa é a releitura de autores greco-latinos sob uma óptica predominantemente medieva.

Enquanto a parte teórica, especialmente de contato e releituras dos clássicos, coube ao Humanismo (movimento intelectual que serviu de base ao Renascimento), a prática, no sentido de exercício das técnicas e teorias trazidas à tona pelos humanistas, se revelou, na Literatura, com o Classicismo.

O termo Classicismo é um dos mais complexos em matéria de sentido, posto que, ao longo de vários séculos, sofreu mutações em virtude de usos temporais ou particulares. Assim, recorre-se à etimologia e à historicização de seus empregos mais comuns, para, então, tecerem-se comentários acerca do vocábulo.

O termo clássico teria origem em classicus, que, em latim, se referia ao cidadão da primeira das cinco classes de riqueza, de acordo com a divisão feita a partir de um censo, ocorrido durante o 
reinado do imperador romano Sérvio Túlio. Nesse sentido, classicus aludia às castas mais altas da sociedade romana, agregando em si conotações políticas e econômicas. Segundo Aguiar e Silva (1973), o primeiro emprego do termo na Literatura foi na expressão classicus scriptor, em oposição à proletarius scriptor, cujo significado relacionava-se à qualidade do autor, sendo, para tal, os critérios de beleza e correção linguística os pontos mais relevantes. No entanto, classicus relacionava-se, no latim baixo, a classes, referindo-se às instituições escolares e, consequentemente, aos autores lidos nas escolas. Acredita-se que esse sentido tenha perdurado até meados do século XVIII, mesclando-se ao sentido de clássico como referência aos autores e à Literatura greco-romana em geral, até adquirir acepção oposta ao romântico, passando, assim, a designar uma estética literária.

Compreenda-se o Classicismo como um movimento intelectual e literário, cuja principal manifestação se deveu à experimentação, especialmente na Literatura, dos recursos neoclássicos propalados pelo Humanismo, como a medida nova, as temáticas clássicas retomadas dos grecoromanos e a presença da mitologia. No entanto, vale recordar que, embora a "prática" de padrões estéticos da Antiguidade tenha sido a marca do Classicismo, não se pode olvidar a presença constante do ideário medieval, cujas bases ainda englobavam boa parte da Europa.

Conforme já foi mencionado, a Nação Lusitana teve a primazia das expedições marítimas, visando à conquista de novos domínios e, consequentemente, possibilidades potenciais de comércio e lucro. Porém, não podem ser desconsiderados os preceitos religiosos e ideológicos que foram contrariados para que se concretizasse a busca por novas terras. O teocentrismo era a ideologia dominante na época e condenava com veemência as ações do homem que pudessem interferir na "vontade divina", representada pela Igreja Católica. Lançar-se ao mar significou, antes de tudo, ir contra uma ordem pré-estabelecida e imutável até então. Além disto, lendas fantásticas acerca de monstros devoradores de navegantes e possíveis caminhos que levassem ao centro da Terra foram vencidas e postas em descrédito a partir da experiência portuguesa.

Desse modo, pode-se afirmar que Portugal foi classicista, no sentido da prática racional e concreta das navegações, desde 1415, antes de ser Humanista (teorização das ideias clássicas). Entretanto, o paradoxo português não se deve apenas a essa circunstância. Embora se apresente como pioneiro das ciências náuticas, a Nação Portuguesa viu-se profundamente arraigada à religiosidade cega durante muitos séculos e à concentração de riquezas nas mãos da Nobreza feudal, o que resultou em um país de façanhas empreendedoras, com mentalidade medieval de administração. Reflexos dessa dicotomia verificam-se em Gil Vicente e Luís de Camões, Literatura com aspectos renascentistas a serviço de valores medievais. 
A partir de 1520, observa-se certa dissonância dos ideais estéticos clássicos, notadamente na Itália, berço do Renascimento. Tais mudanças só chegariam aos demais países da Europa tardiamente. No caso de Portugal, em 1527 o Classicismo ainda era considerado uma novidade estética. Há algum tempo, o período cronológico atribuído ao Classicismo encerrava-se apenas com o início do Romantismo. Tempos depois, inseria-se o movimento Barroco, para remeter ao trânsito entre ambos. No entanto: “(...) a passagem do estilo renascentista para o estilo barroco não se opera de um modo abrupto, manifestando-se entre estes dois estilos um terceiro estilo que não se confunde com nenhum daqueles." (SILVA, 1973, p. 380).

O Maneirismo, termo primeiramente utilizado no campo artístico e depois na Literatura, configurou-se como o período intermediário entre a Renascença e o Barroco. A palavra teria origem em maniera, utilizada na segunda metade do século XVI, para referir-se a um estilo individual, de época ou de nação. Aos que imitavam estilos particulares, convencionou-se chamar de maneiristas, por produzirem à maneira de alguém. Tendências naturalistas posteriores passaram a associar o maneirismo ao estilo falso, cuja representação fugia da natureza dos objetos.

Outra interpretação para Maneirismo seria a restauração do gótico, derivando o preciosismo característico dessa corrente artística. Segundo Aguiar e Silva (1973), as raízes maneiristas estariam em um movimento Antirrenascimento. Tal forma de pensamento teria advindo do fato de que, ao resgatar e praticar os ideais clássicos, equilibrados e harmoniosos, esperava-se encontrar respostas que solucionassem os conflitos de ordem religiosa e social que se evidenciavam na época, porém as concepções humanistas não traziam em si tais problemáticas, pois tinham sido relidas a partir de um modelo clássico, em que essas questões não existiam, resultando em uma espécie de "falha" na base racional.

Nesse sentido, o Antirrenascimento rompe com a normatividade, o rigor, o equilíbrio e a beleza propostos na Renascença, pois seriam representações vazias de significados, sem correspondência com o mundo a seu redor. Busca-se uma estética que reproduzisse: “(...) essa atmosfera de crise e angústia vital" (SILVA, 1973, p. 396) de um mundo desprovido de coerência, similar àquele em que se vive, em que há ceticismo, melancolia e crise.

Acerca das diferenças entre as estéticas Maneirista e Barroca, segundo Vítor Manuel de Aguiar e Silva:

O barroco é profundamente sensorial e naturalista, apela gozosamente para as sensações fruídas na variedade incessante do mundo físico, ao passo que o maneirismo, sob o domínio do disegno interiore, da Idea, se distancia da realidade física e do mundo sensório, preocupado com problemas filosófico-morais, com fantasmas interiores e com complexidades e subtilezas estilísticas; o barroco é uma arte acentuadamente realista e popular, animada de um poderoso ímpeto vital, 
comprazendo-se na sátira desbocada e galhofeira, dissolvendo deliberadamente a tradição poética petrarquista, ao passo que o maneirismo é uma arte de élites, avessa ao sentimento "democrático" que anima o barroco, anti-realista, impregnada de um importante substrato preciosista e cortês, representado sobretudo pelo filão petrarquista; o barroco caracteriza-se pela ostentação, pelo esplendor e pela proliferação dos elementos decorativos, pelo senso da magnificência que se revela em todas as suas manifestações, tanto nas festas de corte como nas cerimónias fúnebres, contrariamente ao maneirismo, mais sóbrio e mais frio, introspectivo e cerebral, dilacerado por contradições insolúveis; o barroco tende frequentemente para o ludismo e o divertimento, enquanto o maneirismo aparece conturbado por um pathos e uma melancolia de raízes bem fundas. (1973, p. 403-5).

Assim, compreende-se que o Maneirismo caracterizou-se pela agudeza das expressões de incoerência do universo, do desengano e da efemeridade, espécie de desajuste, magistralmente representado pelo poeta português Luís de Camões. Há, em sua obra, a exaltação dos feitos humanos, porém também se percebe um sujeito desconcertado, que busca seu lugar no mundo.

\subsection{Camões: o homem ignoto por trás do gênio poético}

A obra de Camões é, sem dúvida, um dos elementos mais representativos de Portugal no período das grandes navegações. No entanto, embora muito se especule a respeito de sua vida, especialmente no que diz respeito à sua origem, envolvimentos amorosos e formação, não se dispõe, quatrocentos anos após sua morte, de respostas definitivas a esses questionamentos. Há apenas três documentos originais e inquestionáveis acerca do poeta: a carta de perdão do rei pela agressão a um funcionário do Paço, datada de 1553; a autorização de publicação d'Os Lusíadas, de 1572; e o alvará de concessão da tença (quinze mil réis) durante três anos, em reconhecimento ao trabalho do poeta. Há, também, quatro documentos que indicariam a prorrogação do pagamento da tença pelos anos seguintes à publicação do livro.

Além das informações advindas dessas fontes, têm-se aquelas de origem menos imparciais, já que trazem em si os recortes e pretensões dos biógrafos do vate. O primeiro deles foi Pedro Mariz, que ao tempo da morte de Luís de Camões contava trinta anos e, em virtude de ser seu contemporâneo, acreditou-se por longo período na fidelidade de seu relato. Sua obra não menciona a formação de Luís de Camões, nem tampouco o que teria feito antes de alistar-se com destino à Índia, aos vinte e cinco anos. O biógrafo aponta a existência de um escravo Jau, de origem javanesa, cuja arrecadação de esmolas teria garantido a sobrevivência do poeta. Pedro Mariz atribui os infortúnios vividos pelo vate a seu comportamento ingrato para com aqueles que supostamente quiseram ajudá-lo. 
Nova biografia viria a público no livro do cônego de Évora, Manuel Severim de Faria, nascido meia década após a morte de Luís de Camões. Embasando suas afirmações a partir da obra do poeta, mesmo sem a devida comprovação do que seria ou não de autoria camoniana, o religioso evidencia a possível formação cultural em Coimbra, legando à marginalidade a História do escravo ou a existência de um mecenas que teria financiado o vate em seus últimos anos de vida.

Os livros de Manuel Faria de Sousa, publicados em 1639 e após sua morte, em 1685, trariam certo avanço no esclarecimento de dados. O autor destina especial atenção aos infortúnios vividos por Camões, que teriam sido causados pela interferência de uma família de prestígio da época, que o poeta servira e, por motivos desconhecidos, o perseguiu. Não se sabe se por influência dos descendentes da família mencionada ou por razões escusas, o autor da biografia teve seu nome envolvido em campanhas de descrédito, que ainda hoje influenciam quem o lê.

O século XVIII foi marcado por visões romanescas acerca da vida de Camões, especialmente no que concerne à hipótese de seu envolvimento amoroso com a Infanta D. Maria, irmã do rei D. João III. Um dos maiores defensores dessa hipótese foi José Maria Rodrigues.

Trabalho decisivo foi realizado pelo Visconde da Juromenha em 1860, cuja pesquisa sistemática nos arquivos públicos permitiu localizar os documentos autênticos que formam a base dos estudos camonianos até o presente. A última biografia acerca de Luís de Camões veio pela obra ficcional de Aquilino Ribeiro, na qual o cruzamento entre os dados conhecidos e a narrativa leve permitiu trazer à tona o autor d'Os Lusíadas de uma maneira um tanto menos controversa do que de costume.

O entrave ao progresso dos estudos camonianos estaria relacionado a duas questões que se ecoam mutuamente, sendo elas: Qual seria a relação existente entre Camões e sua obra? O que é a obra de Camões? A ponte, ou a ausência dela, entre a vida e a obra de Luís de Camões só pode ser erguida sobre alicerce forte, seja no que diz respeito à vida ou aos textos efetivamente de sua autoria. Conforme previamente mencionado, faltam dados que revelem o que o escritor fez em vida. Assim, o professor Emanuel Pereira Filho lançou mão do critério da tripla abonação (existência de três documentos dignos de fé que conferiam a autoria de um determinado texto) para permitir a reunião dos escritos genuinamente camonianos. Com a aplicação desse critério, reduziu-se de quinhentos e noventa a três para sessenta e cinco os poemas atribuídos ao autor, o que teria ocorrido em virtude de confusões anteriores entre o estilo camoniano e o estilo geral do Quinhentos. Como fator agravante ao emprego do critério de legitimidade, não se tem qualquer amostra da caligrafia de Luís de Camões.

José Hermano Saraiva, em Vida Ignorada de Camões, sintetiza o assunto: 
Em resumo: o que hoje se sabe sobre a vida de Camões é menos que o que, em 1629, Faria e Sousa publicou. O estado dos actuais conhecimentos é ainda fundamentalmente o que foi fixado em 1860 pela biografia de Juromenha, com uma ou outra correcção de pormenor que não esclarece o conjunto. Continua portanto a ignorar-se quase tudo. (SARAIVA, 1978, p. 14).

Luís de Camões, considerando os documentos conhecidos e as hipóteses mais bem fundamentadas, teria nascido entre 1524 e 1525, provavelmente em Lisboa ${ }^{14}$. Originário de uma família sem riquezas, que, ao que tudo indica, pertencia à pequena nobreza, desde jovem estaria a serviço de D. Francisco de Noronha ${ }^{15}$. Teria frequentado a escola de artes de Coimbra, seja por influência do tio ou por ser esse o caminho que algum protetor lhe havia traçado. Nesse tempo, teve contato com a cultura humanística clássica, que lhe conferira os conhecimentos que demonstrou por meio de seus escritos. O jovem dividiria seu tempo entre os estudos acadêmicos e a vida boêmia de Lisboa. A esse respeito, acredita-se que o poeta frequentava o Mal-Cozinhado, espécie de prostíbulo famoso da época. O escritor representou na casa de Estácio da Veiga, funcionário renomado, a peça teatral El-Rei Seleuco e dois outros autos, a saber, Auto de Filodemo e Anfitriões.

A representação da peça El-Rei Seleuco, embora no texto de Helder Costa ocorra na casa de Estácio da Fonseca e não na de Estácio da Veiga, é o ponto de partida do dramaturgo português contemporâneo, na tentativa de (re)apresentar no palco uma personagem que preencha, de modo satisfatório, o ideário que se tem da personagem histórica de Camões. Helder Costa trabalha com a representação mental coletiva que se construiu do vate ao longo dos anos, aliando os fatos históricos conhecidos e os narrados n' Os Lusíadas para criar o efeito de verossimilhança no texto teatral, sem, no entanto, deixar de apontar, segundo sua mundividência, os "equívocos" que a aura gloriosa das expedições ultramarinas portuguesas encobre.

Há diversas especulações a respeito dos supostos envolvimentos do vate em desordens públicas e com altas damas, dentre as quais D. Violante, esposa de seu amo, e a Infanta D. Maria, para citar apenas as mais polêmicas, teriam lhe rendido o desterro para Ceuta, provavelmente entre 1547 e 1548. Em seu regresso, Camões trazia consigo a marca da batalha: perdera a vista direita em combate.

Atribui-se ao seu comportamento indisciplinado e à sua origem humilde o fato de seu nome estar ausente dos círculos de ilustres escritores da época, em que figuravam nomes como o de António Ferreira. Desprovido de recursos, Camões teria se alistado como soldado em 1550, sem, no entanto, embarcar. Dois anos mais tarde, após uma briga com um funcionário do Paço, Gonçalo ou

\footnotetext{
${ }^{14}$ Informações extraídas do livro Vida Ignorada de Camões, de José Hermano Saraiva.

${ }^{15}$ Possivelmente a personagem histórica era um funcionário influente na Corte Joanina, porém, na peça de Helder Costa, o nome da personagem aparece modificado, a saber, Fernando de Noronha.
} 
Gaspar Borges, Camões é preso por cerca de nove meses na prisão do Tronco. Sua liberdade ficaria condicionada ao embarque imediato rumo à Índia, conforme documento oficial de perdão real, emitido em 1553.

Chegando em Goa, ainda no mesmo ano, participa de expedição à ilha de Porcá contra o rei de Chembe. Nova expedição o levaria ao Golfo Pérsico. Em homenagem ao novo governador, Francisco Barreto, apresenta o Auto de Filodemo. No período entre 1556 e 1561, atribuem-se mais duas prisões a Camões, sem que haja registro dos motivos. Liberto por intervenções externas, o soldado é nomeado provedor mor dos defuntos e ausentes em Macau. Não se sabe se em consequência de viagem à China para prestar contas pela acusação de roubo ou se por infeliz fortuna, Luís de Camões sofre naufrágio na foz do Rio Mekong, em que teria salvado seu manuscrito d'Os Lusíadas e perdido a companheira chinesa.

Novamente em Goa, envolve-se em problemas que o levam à cadeia, acredita-se que em consequência de dívida com Miguel Fios Secos. Alcançada a proteção do vice-rei D. Francisco Coutinho, recebe um mote para glosar e uma ode para recomendar o livro Colóquio dos simples $e$ drogas e coisas medicinais da Índia, editado em 1563, de autoria de Garcia da Orta ${ }^{16}$. Em 1567, quando as aflições financeiras já o consumiam, acompanhado de Pêro Barreto, vai para Moçambique, visando a retornar a Portugal. Não se sabe o motivo exato, porém, a ausência de recursos talvez seja o que melhor explique sua permanência naquele local até 1569, quando encontra seu amigo Diogo do Couto, que, juntamente com outros, lhe teriam financiado o retorno a Portugal.

Ao desembarcar em Cascais, em consequência da peste que assolava Lisboa, tratou dos preparativos para a publicação de sua epopeia. Teria ido buscar apoio financeiro com a família de Vasco da Gama, que lhe teria negado auxílio. Após longo processo e "ajustes" com o censor do livro, Frei Bartolomeu Ferreira, Os Lusíadas foi finalmente publicado. A concessão da tença anual de quinze mil réis ao poeta não foi suficiente para diminuir-lhe a pobreza. Luís de Camões teria morrido em 1580, enterrado em cova rasa na Igreja de Santa Ana, e sem que a obra de sua vida lhe rendesse as honras almejadas. Em 1582, o rei Filipe II concede a Ana de Sá, mãe de Camões, o pagamento de seis mil réis, em reconhecimento aos serviços prestados por seu filho. Nesse período, a epopeia já contava com traduções em castelhano.

A vida de Luís de Camões não é um assunto consensual aos que trabalham com o autor. No entanto, há de se concordar que sua vida e obra foram: “(...) uma experiência pessoal múltipla que nenhum outro escritor contemporâneo realizou (...)" (SARAIVA, 2010, p. 312). Camões teria sido,

\footnotetext{
${ }^{16}$ Filho de cristãos-novos espanhóis, nasceu em Portugal, formando-se em medicina, tendo inclusive tratado do rei D. João III. Mudou-se para a Índia como o médico pessoal de Martim Afonso de Souza, tendo ali permanecido até sua morte, em 1568.
} 
nesse sentido, um poeta prático, na medida em que, por meio de suas experiências, foi: “(...) capaz de dar forma lapidar e definitiva a um conjunto de ideia, valores e tópicos característicos da sua época. (...) Camões assumiu e meditou a experiência de toda uma civilização cujos conflitos viveu na sua carne e procurou superar pela criação artística” (SARAIVA, 2010, p. 312-3).

Seus temas líricos mais recorrentes são o amor, frequentemente idealizado, e o desconcerto do mundo, tratados com a erudição e limpidez da escrita, além do dualismo entre a experimentação do conhecido e a surpresa do desconhecido. Tais características também são associadas à personagem ficcional criada por Helder Costa, visto que o vate age em consonância com seus escritos, configurando-se como um homem visionário, à frente de seu tempo. Os Lusíadas é apresentado no texto teatral como uma narrativa poética, fruto do que o autor vivenciou na prática, posto que ele próprio teria participado da expedição de Vasco de Gama.

Embora seja predominantemente laudatória, a obra camoniana Os Lusíadas conta com episódios críticos com relação às expedições, especialmente na figura do Velho do Restelo, que personifica as vozes contrárias às aspirações portuguesas, em vista das inúmeras perdas que elas geraram, tanto financeiras quanto humanas. Associa-se, ainda, aos raros momentos pessimistas da obra, os versos finais, quando o poeta aponta, em tom desiludido, os vícios dos portugueses:

Não mais, Musa, não mais que a Lira tenho / Destemperada e a voz enrouquecida, / E não do canto, mas de ver que venho / Cantar a gente surda e endurecida. / O favor com que mais se acende o engenho, / Não no dá a pátria, não, que está metida / No gosto da cobiça e da rudeza / Duma austera, apagada e vil tristeza. (CAMÕES, 1993, p. 387 - Canto X, 145).

1.5 Diogo do Couto: cronista crítico de seu tempo

Ao contrário de Camões, há registros bastante concretos em torno da vida e obra de Diogo do Couto $^{17}$. Nascido em Lisboa, ao ano de 1542, não era fidalgo de berço, embora seu pai, Gaspar do Couto, tenha recebido o título em 1535, como recompensa aos serviços prestados ao Infante D. Luís, filho de D. Manuel. Diogo do Couto foi criado no palácio do príncipe, frequentando, aos onze anos, o colégio dos jesuítas de Santo Antão. Posteriormente, recebeu lições de Filosofia no mosteiro de Benfica, em companhia de D. António, filho do Infante.

${ }^{17}$ Informações extraídas de: http://www.infopedia.pt/\$diogo-do-couto. Acesso em: Jan. 2015; COUTO, Diogo do. $O$ Soldado Prático. Texto restituído, prefácio e notas pelo professor M. Rodrigues Lapa. Lisboa: Editora Lisboa, 1937. 
A morte de seu protetor, D. Luís, destina Diogo do Couto a servir como moço de câmara do rei, espécie de camareiro, cuja responsabilidade principal era cuidar dos aposentos reais. Em constante convivência com pessoas e ideias de valorização da Nobreza advinda do berço, sente-se diminuído por sua origem humilde. Assim como muitos sonhadores de sua época, vê no embarque para a Índia uma possibilidade de tornar-se valoroso por mérito, e não por descendência. O jovem inicia sua empreitada após a morte do pai, embarcando em 1559 na frota de Pero Vaz de Siqueira ${ }^{18}$, rumo ao encontro de novos horizontes.

Em seus anos de combate, integrou a campanha Surrate, em 1560, sob o comando de D. António de Noronha ${ }^{19}$. Em 1563, encontrava-se em Baroche $^{20}$, ainda como soldado. Teria participado também da expedição de D. Antão de Noronha ${ }^{21}$ contra Mangalore $^{22}$, em que Diogo do Couto presenciou cenas de massacre, às quais o cronista se refere na Década VIII. Acompanhando D. Antão rumo ao reino, parte em 1569, quando, em parada por Moçambique, encontra Luís de Camões em estado de penúria. Segundo registros do cronista, o governador Pedro Barreto Rolim tentou ajudar o poeta, tendo desistido em função da postura resistente do vate. Partem para Portugal juntos; Luís de Camões a dar retoques finais à sua epopeia e a compilar seu Parnaso (reunião de poemas), enquanto Diogo do Couto concentra-se em tecer um comentário histórico acerca d'Os Lusíadas. Ao desembarcarem em Cascais, pois Lisboa era assolada pela Peste, Couto foi ao rei em Almeirim prestar contas dos negócios feitos na Índia. Integrando novamente a armada de D. António de Noronha, parte, no ano de 1571, em auxílio a D. Jorge de Castro $^{23}$ em Chale, Índia. Anos mais tarde, obtém elevado cargo de empregado nos armazéns de mantimentos, casando-se com Luísa de Melo e instalando-se definitivamente em Goa.

Em 1593, presta contas de seu primeiro trabalho histórico, passando a ser responsável por organizar o arquivo e continuar as crônicas de Goa, interrompidas pela morte de João de Barros ${ }^{24}$ (1570). Diogo do Couto teve, possivelmente, compromisso com a veracidade dos fatos, o que, em primeira análise, é a missão daqueles que se propõem a registrar os episódios pretéritos. Porém, como bem adverte Rodrigues Lapa:

O historiador era agora um cortesão, sem independência material nem moral; e o rei, a pouco e pouco deixou de ser o rei popular, para ser o ditador absoluto, a

\footnotetext{
${ }^{18}$ Capitão-mor de uma embarcação de cinco naus que, em 1559, partiram rumo à Índia.

${ }^{19}$ Militar português, foi o vigésimo quarto governador da Índia e o décimo primeiro vice-rei da Índia.

${ }^{20}$ Região da Índia.

${ }^{21}$ Militar e nobre português que teria sido governador de Ceuta em 1549, além de vigésimo segundo governador da Índia e nono vice-rei da Î́ndia, de 1564 a 1568.

${ }^{22}$ Cidade costeira próxima a Goa, Índia.

${ }^{23}$ Capitão de armada, que teria morrido em combate em Tânger.

${ }^{24}$ Primeiro grande historiador português, foi pioneiro da gramática da língua portuguesa, tendo escrito o segundo livro conhecido a normatizar o idioma.
} 
quem tudo se devia. Nestas condições, compreende-se bem que o objectivo da História já não podia ser a simples e total verdade, mas apenas a verdade que agradava ao senhor, que redundasse em seu prestígio. (1972, p. v-vi).

Em virtude do modo fidedigno como escreveu seus registros, incomodou a alta corte com suas críticas. Observe-se, a este respeito, o seguinte excerto, presente na introdução de seu livro: “O amor da verdade é em Couto uma espécie de vício. Há homens assim; por mais que lhes façam, não cessam de dizê-la; faz parte da sua natural respiração." (COUTO, 1937, introdução, p. xxx). Seu afastamento foi sugerido em carta pelo rei D. Filipe II, influenciado pela aristocracia que o rodeava. Couto, no entanto, mantém o cargo, por proteção de D. Francisco da Gama ${ }^{25}$, retirando de seu ordenado as fontes para financiar a publicação de seus outros escritos, dentre eles $O$ Soldado Prático, no qual denuncia com veemência os enganos e desenganos das expedições à Índia.

$\mathrm{O}$ argumento principal da narrativa se desenvolve a partir do diálogo entre o Soldado, o Despachador e o Fidalgo, quando o primeiro vai à casa do segundo para entregar sua petição e os papéis que atestavam os longos anos de serviço prestados na Índia em nome do Rei. Iniciam-se reflexões acerca das condições a que os soldados originários de famílias pouco favorecidas eram submetidos, tais como a fome e o abuso de poder, além do fato que causará maior espanto aos ouvintes do relato: a desonestidade dos nobres que ocupavam posições privilegiadas no governo indiano e, por meio das quais, tiravam vantagens e relegavam a segundo plano os interesses da Coroa.

Afligido por sobressaltos e instabilidades, Diogo do Couto falece em 10 de dezembro de 1616. Pode-se inferir que Camões e Diogo do Couto fizeram obras complementares. O primeiro eternizou os feitos heroicos do passado, mitificando as potencialidades das descobertas marítimas, enquanto o segundo lamentou o seu próprio tempo, em que predominava a corrupção, o roubo e a ambição, chagas profundas no "ilustre peito lusitano".

\subsection{Considerações gerais acerca do capítulo}

Nesse capítulo, percorreu-se a História de Portugal, desde sua formação como reino independente, quando a identidade lusitana passou a formar-se. Note-se que o país foi o primeiro a lançar-se ao mar em busca de traçar uma rota que fornecesse recursos econômicos para sua precária administração financeira. Embora essencialmente desbravador, o país esteve atrelado à conservadora mentalidade medieva católica, mesmo que essa fosse paradoxal às expedições.

\footnotetext{
${ }^{25}$ Nobre e militar português, foi duas vezes governador e vice-rei da Índia. Era bisneto de Vasco da Gama.
} 
Portugal tornou-se o centro do mundo, consolidou-se como figura relevante pelo papel que desempenhou nas novas descobertas ultramarinas, as quais, no ideário popular, foram sedimentadas como o período áureo da Nação.

Helder Costa, consciente do evidente declínio dessa posição privilegiada, faz uma releitura desmistificadora desse período, propondo a reconstrução, a partir da reflexão, do que ainda predomina na essência lusitana desse povo que foi, mas não se dá conta de que, no presente, precisa ser.

Nesse sentido, o conhecimento da História Portuguesa permite compreender melhor os pontos de apoio de Helder Costa em seu texto teatral, além de evidenciar a urgência que o dramaturgo demonstra em destruir o ideário de que as navegações portuguesas foram o auge da nação, na tentativa de, a partir da desconstrução, erguer um novo ser lusitano, que, embora contemple o passado, viva e atue no presente, a fim de melhorá-lo efetivamente.

As personagens Camões e Diogo do Couto, além da própria História Portuguesa, são utilizadas para que haja o inicial reconhecimento e a consequente aceitação do que é representado, no intuito de que, a cada episódio relido, o espectador se depare com uma série de pontos negativos a respeito do que lhe é canônico, resultando no efeito de estranhamento, que leva à posterior análise crítica, mediada, ao fim e ao cabo, pela cosmovisão do dramaturgo Helder Costa. 


\title{
2 ABREM-SE AS CORTINAS
}

\begin{abstract}
Quando encontramos um amigo cansado de uma longa viagem, damos-lhe roupa nova, alimentação, falamos com ele do que se passou na sua ausência, ensinamos-lhes as palavras que mudaram, os novos hábitos que surgiram, e dizemos-lhe que é preciso voltar a encontrar uma linguagem e um pensamento comuns. Conversa por vezes difícil, e nem sempre bem sucedida, mas entre amigos tem sempre de se tentar.
\end{abstract}

COSTA, 1994.

Antes da abertura total das cortinas que indicam o início do espetáculo ou, nesse caso, da análise do texto teatral de Helder Costa, faz-se necessário ir aos escritos de Décio de Almeida Prado no livro A Personagem de Fiç̧ão (2009), onde se discute a respeito das personagens do teatro, que, segundo o teórico: “(...) constituem praticamente a totalidade da obra: nada existe a não ser através delas. (...) tanto o romance como o teatro falam do homem - mas o teatro o faz através do próprio homem, da presença viva e carnal do ator” (p. 84)

A criação de uma personagem é uma espécie de construção particular, orquestrada tanto pelo autor quando escreve a peça quanto pelo ator durante a performance. Porém, A Viagem - Camões Poeta prático não se esteia apenas na liberdade criativa de Helder Costa na composição das personagens, mas abarca também referências concretas, pois tem modelos históricos como personagens ficcionais.

O nome Camões em si, ainda que atribuído a uma personagem sem qualquer ligação direta com a pessoa histórica, implica referência ao poeta lusitano. Considerando que a peça teatral em análise reconta a expedição de Vasco da Gama a partir da vida e obra do Camões histórico, não é possível afirmar que o vate do texto teatral é apenas ficção, enquanto "invenção" do autor, mas o resultado do "transplante" de uma personagem histórica, retirada de seu contexto original, para outro que, embora se assemelhe em alguns aspectos ao contexto primeiro, atende aos propósitos do escritor Helder Costa no momento da escrita.

Assim, deve-se distinguir três personagens Camões que se fazem presentes, direta ou indiretamente, na peça. A primeira remete à personagem histórica do bardo, que viveu entre $1524 \mathrm{e}$ 1580, acerca da qual pouco se tem comprovado por documentos. A essa se passará a nomear $\mathrm{CH}$ (Camões histórico). A segunda personagem remete a CHF (Camões histórico ficcionalizado), construída a partir da fusão de $\mathrm{CH}$ e a mundividência de Helder Costa para atingir a finalidade de sua proposta teatral. Por fim, há CAI (Camões analítico interpretativo) para referir-se à interpretação que se fará da personagem do texto teatral a partir de $\mathrm{CH}$ e $\mathrm{CHF}$. 
Cabe, ainda, a título de esclarecimento, reiterar as principais vias pelas quais se compõem as personagens: por meio do que elas revelam acerca de si mesmas, por suas ações ou pelo que os outros dizem a seu respeito. No caso da personagem CHF, tanto as ações, no caso o modo como se comporta, os ambientes que frequenta e as companhias que a cercam, quanto o que as demais personagens dizem acerca dela, são resultado da constante recriação do que popularmente se atribui a $\mathrm{CH}$, somado ao que Helder Costa almeja colocar no palco para seu público.

A necessidade humana de atribuir nome às coisas do mundo é uma característica acentuada, desde os mais remotos tempos de que se tem registro. Por meio do ato de nomear, o homem infunde vida ao que pode reconhecer, estabelecendo, assim, uma relação única e familiar com o que nomeia. De maneira similar, ao intitular um texto, o autor busca exprimir, por meio de palavras-chave, o sentido geral de sua produção, constituindo o título como uma amostra do conjunto da obra, estabelecendo com esta uma relação metonímica. Além da função mencionada, o título também tem por objetivo estimular a curiosidade do espectador ou, no caso da análise textual, o leitor.

A análise do texto teatral deve ser precedida da observação de seu título, a fim de que esse ilustre, ainda que não de modo evidente, o que o autor considera significativo para estabelecer a comunicação imediata com o público, antes mesmo que o espetáculo se inicie.

A palavra viagem tem origem etimológica no provençal viatge, cujo correspondente em latim é viaticu, que significa jornada, ou, ainda, provisões para uma jornada. Note-se que, ao longo dos anos, o vocábulo passou a ser empregado para denominar também o percurso extenso entre um ponto de partida e de chegada. Com o decorrer do tempo, a palavra passou a ser combinada com outras, fazendo surgir expressões como viagem de descoberta e viagem de longo curso, que associavam o sentido de jornada ao objetivo que as originava.

O Dicionário de Símbolos de Juan-Eduardo Cirlot sugere, para a palavra viagem, a acepção de que "viajar é procurar", de modo que se relaciona à “(...) tensão da busca e da mudança determinada pelo movimento e pela experiência que deriva do mesmo.” (1984, p. 598-99). A ideia de aspiração, desejo e anseio, relacionada à viagem, aparece também no Dicionário de Símbolos de Jean Chevalier e Alain Gheerbrant, embora possa diferir o objetivo da busca, "seja da verdade, da paz, da imortalidade, da procura e da descoberta de um centro espiritual" (1990, p. 951).

Nesse sentido, pode-se inferir o duplo emprego da palavra viagem no título da peça, seja ele literal, referindo-se à viagem ultramarina portuguesa que CHF participa, ou, em sentido abstrato, aludindo ao processo de autoconhecimento pelo qual CHF passa antes da escrita d'Os Lusíadas.

$\mathrm{O}$ sentido da palavra viagem não parece se restringir apenas a $\mathrm{CHF}$, expandindo-se para o texto teatral como um todo, na medida em que esse propõe que o espectador viaje, busque, ao longo de toda a peça, revisitar o período tido como áureo pelo ideário português, entre os séculos XV e 
XVI, quando o país esteve no centro dos acontecimentos históricos da época. Em sentido metafórico, o termo viagem poderia ser aplicado à procura de novos sentidos para o passado histórico, mote do texto teatral, cujo percurso é traçado a partir desse anseio de buscar uma nova visão acerca do que se conhece.

A segunda palavra a ser analisada no título é a evocação da personagem $\mathrm{CH}$. A escolha do poeta como protagonista não deve ser compreendida como acaso, visto que, conforme se mencionou no capítulo anterior, quando foram trazidos à baila alguns aspectos históricos das principais personagens aos quais a ficção se refere, levantou-se o fato de haver poucos registros efetivos acerca da vida do vate. Logo, o que se sabe a seu respeito, em larga escala, é resultado de hipóteses, com escassa documentação comprobatória. No entanto, $\mathrm{CH}$ integra o imaginário coletivo português com enorme relevância, gerando o que se referirá por representação mental coletiva. Em outras palavras, embora não se tenha certeza de diversos aspectos da vida de $\mathrm{CH}$, existe um ideário de especulações, que adquiriram o simulacro de verdade quanto à História do escritor, associando-o, quase que inconscientemente, a um estereótipo construído por biógrafos, críticos e leitores de sua obra. Além disso, $\mathrm{CH}$ teria vivido durante o contexto em que se ambienta a peça, configurando-se como ideal protagonista, posto que reúne duas características fundamentais: é um autor representativo do período de ambientação da peça, além do fato de ser personagem obscura da História, o que permite que Helder Costa preencha da maneira que melhor lhe convier as "lacunas", de modo a criar CHF, que irá atender ao propósito de um teatro épico em sentido brechtiano.

Sabe-se pouco ou quase nada de fato acerca de $\mathrm{CH}$, porém esse existe enquanto personagem figurativa da coletividade portuguesa, logo a caracterização de CHF oscila entre o cavalheiro que luta para defender uma donzela moura em perigo, o assíduo frequentador de bordéis, o poeta valoroso, o amante que repete os mesmos belos versos para conquistar diferentes mulheres, o bem humorado autor que parodia a tragédia de Romeu e Julieta e o apaixonado que busca por um ideal amoroso. Todas essas oscilações têm por finalidade abarcar a representação mental coletiva que se tem em torno de $\mathrm{CH}$, a fim de que o espectador reconheça, em maior ou menor medida, $\mathrm{CHF}$ como $\mathrm{CH}$. No entanto, CHF demonstra, ao longo de todo seu percurso dentro do texto teatral, ser um visionário, distinguindo-se nesse sentido de $\mathrm{CH}$. Camões, personagem histórica, poderia ter escrito a respeito de estereótipos viciosos, considerando a escrita de seu período, porém, não seria verossímil considerá-lo capaz de apresentar uma visão tão acurada de seu próprio tempo, especialmente no que tange às críticas feitas na peça. Nesse ponto se faz sentir a "mão" do autor, ou seja, CHF em certa medida remonta $\mathrm{CH}$. Contudo, aquele tem a cosmovisão de Helder Costa em relação ao passado e não a visão contaminada pelo próprio tempo em que se situa como $\mathrm{CH}$. 
A terceira parte do título da peça, Poeta prático, assemelha-se a uma definição de CHF. O termo poeta vem do grego poiētếs, que significa autor ou criador. Segundo a tradição, o poeta era aquele que, inspirado pelas musas, escrevia em versos os grandes feitos de heróis. Assim sendo, ao designar CHF como poeta, refere-se, em primeira instância, à sua habilidade como arauto, característica de $\mathrm{CH}$.

Já com relação ao adjetivo prático, associado ao substantivo poeta, em referência a CHF, há de se observar a etimologia da palavra. Prático é derivado do grego praktikée, ou seja, aquele que tem a práxis, a prática de uma determinada atividade. A fim de entender as implicações do adjetivo prático em questão, faz-se necessário remontar às associações antigas que eram feitas à figura dos poetas. Tinha-se na figura do escritor aquele que se dedicava ao cultivo exaustivo da arte das palavras, atividade que exigia dedicação exclusiva. Por consequência dessa necessidade, pessoas advindas de camadas mais pobres da população não dispunham de condições financeiras favoráveis, que lhes permitissem dedicar-se exclusivamente à escrita. Assim, a arte da escrita era desenvolvida com maior frequência por pessoas das camadas abastadas, ou mesmo por aqueles que contavam com o apoio de mecenas que os financiassem. CHF apresenta-se como uma exceção a essa regra, pois, embora dedicasse seu tempo à escrita, não deixou a práxis de lado, servindo como soldado nas Índias. A palavra prático associada a CHF indica que esse se caracterizou não só pela arte de cantar seu tempo e as glórias da Pátria, mas por suas experiências práticas de vida.

Outra acepção da palavra "prático" remete ao profissional que, por seu conhecimento minucioso e detalhado do relevo de determinado recife, é responsável por guiar os navios na entrada e na saída do porto. De certa forma, o prático é aquele que tem o conhecimento real do território e o utiliza para nortear os que não o tem. Nesse sentido, poderia inferir-se CAI como figura norteadora do percurso das navegações ultramarinas, visto que integrou, adquirindo experiência prática, a esquadra de Vasco da Gama. Por isso, qualifica-se como voz significativa acerca do período em questão.

O adjetivo prático evoca o diálogo intertextual com o livro O Soldado Prático, de Diogo do Couto, cujo tema principal está precisamente em trazer à tona, a partir da experiência vivenciada por uma das personagens, os aspectos negativos das expedições ultramarinas no além-mar. O ponto fulcral do texto teatral repousa no desmascaramento da hipocrisia e da degradação moral da sociedade portuguesa, sobretudo dos homens do poder, ensimesmados, manipuladores e desleais com suas obrigações em relação à Coroa.

O texto teatral A Viagem - Camões - Poeta prático, publicado em 1979, é composto por dois atos, com sete cenas no primeiro e cinco no segundo. Porém, por critérios que visam à facilitação da análise, dividiu-se a peça em dois capítulos, respectivamente antes da viagem e, no 
capítulo subsequente, após a viagem. Vale elucidar que o título de cada cena tem por função sintetizar seus mais significativos acontecimentos.

\subsection{Cena I - Ato I - Camões apresenta El-Rei Seleuco ${ }^{26}$}

CHF apresenta o texto teatral de $\mathrm{CH}$ dentro da peça de Helder Costa, evidenciando o aspecto metalinguístico dessa cena, na medida em que discute a arte teatral por meio da representação de uma. O caráter metalinguístico permite a Helder Costa intervir em duas esferas da representação, a macro, considerando A Viagem - Camões - Poeta prático como um texto teatral de releitura intertextual, e a micro, nos fragmentos das obras de $\mathrm{CH}$ ali presentes. Além da dilatação dos campos de intervenção, há também a conquista de certa liberdade dos aspectos crítico-reflexivos, já que esses estarão diluídos nas duas esferas de composição do texto.

A apresentação d'El-Rei Seleuco é ambientada na casa de Estácio da Fonseca ${ }^{27}$, onde, conforme o título da cena e a fala da personagem sugerem, será representada a farsa camoniana.

ESTÁCIO DA FONSECA - Meus Senhores, o nosso amigo Luís Vaz de Camões, quis-nos honrar, e representar aqui, uma farsa. (...) O autor disse-me que era boa obra, e que só os maldizentes é que não gostavam dela. (COSTA, 1982, p. 25).

A legitimação da qualidade da peça a ser apresentada é feita por meio do indicativo de que a obra artística é "boa”, e apenas aqueles que não têm credibilidade, os maldizentes, não a apreciam. Assim, há a divisão de duas categorias de espectadores: os que apreciam a obra e os que, por serem difamadores, não lhe percebem o valor. Considerando os recursos épicos do teatro brechtiano, podese afirmar que a personagem ficcional de Estácio da Fonseca desempenha quase que o papel de "narrador", dirigindo-se tanto ao público de El-Rei Seleuco, quanto aos espectadores da peça de Helder Costa, com o intuito de situá-los a respeito do que se desenvolverá na cena.

Ainda a propósito da fala da personagem, observe-se a escolha lexical do termo farsa, cujo emprego remete ao sentido literário do vocábulo, como:

\footnotetext{
${ }^{26}$ A autoria camoniana de El-Rei Seleuco não é consensual, posto que esta só foi trazida a público em 1654, em uma publicação de Rimas. A discordância autoral se deve a divergências com relação a outros textos do autor, em aspectos como extensão, existência de prólogo e erudição empregada no texto.

${ }^{27}$ Personagem histórica, enteado de Duarte Rodrigues, reposteiro do rei D. João III, teria cedido sua residência para algumas apresentações dos trabalhos de $\mathrm{CH}$.
} 
(...) o alimento temperado que serve para rechear (em francês, farcir) uma carne indica o caráter de corpo estranho desse tipo de alimento espiritual no interior da arte dramática. (..) À farsa geralmente se associa um cômico, grotesco e bufão, um riso grosseiro e um estilo pouco refinado (...) A farsa é oposta ao espírito, que ela está em parte ligada ao corpo, à realidade social, ao cotidiano (...) A farsa sempre é definida como forma primitiva e grosseira que não poderia elevar-se ao nível da comédia. (PAVIS, 2008, p. 164).

Em outro sentido da palavra, farsa consiste em uma "ação ou representação que induz ao logro" 28 . Por considerar farsa nesse último sentido, alguns espectadores associam o conteúdo da peça a um episódio histórico ocorrido na Corte Portuguesa, reagindo de maneiras diversas a respeito do que é representado.

EMBUÇADO: É uma infâmia falar aqui do casamento de D. Manuel com D. Leonor.

UM ESPECTADOR: Infâmia é D. Manuel ter roubado a noiva ao filho...

UM PADRE: Mais infâmia é o Infante D. João dormir com a madrasta e atraiçoar o pai...

ESTÁCIO DA FONSECA: Calma, calma! Nada de irritações! Isto é uma farsa, o nosso amigo Camões não iria meter-se nesses assuntos. Todos conhecemos o perigo que existe em falar das histórias da Corte, e o respeito que devemos a Suas Altezas.

CAMÕES: É só uma farsa. Para rir do cabo até a ponta. Esperem pelo fim. (COSTA, 1982, p. 28).

Cabe salientar a presença do Embuçado, personagem que aparece com o rosto coberto, servindo tanto como elemento de estranhamento, ausência de identificação com o público, quanto como elemento prático da organização teatral, podendo ser representado por qualquer ator que não estivesse no palco durante determinada cena.

A plurissignificação de farsa é retomada na fala de Estácio da Fonseca, quando esse tenta acalmar o público, enfatizando o perigo de se zombar das histórias relacionadas à Corte. $\mathrm{Na}$ sequência, CHF reitera o caráter burlesco de sua produção, associando-a fortemente ao seu sentido risível. Tal procedimento pode ser compreendido como um recurso épico, visto que tem como função causar o afastamento do público em relação ao que é representado. Para isso, considere-se que só é plausível rir daquilo com o que não há identificação, posto que rir de si mesmo é, em última instância, rebaixar-se.

Os possíveis problemas que o poeta português poderia vir a ter em função da referência à realeza são aludidos quando ele apresenta a peça:

${ }^{28}$ Disponível em: http://houaiss.uol.com.br/busca?palavra=FARSA. Acesso em: 23 mar. 2104. 
CAMÕES: É lei de direito, assaz verdadeira,

Julgar por si mesmos aquilo que vêem;

Porque eu cuido que zombo de alguém,

E cuido que zombo da mesma maneira.

Ficam todos bem avisados: isto é para rir, do cabo até a ponta.

Mentira ou verdade, aqui vai a história.

Fala de um Rei muito antigo, El-Rei Seleuco.

Gostem ou não gostem, tanto faz. (COSTA, 1982, p. 25).

CHF ressalta o caráter cômico de sua peça, advertindo ao público que não se trata de mentira ou verdade, mas de História, ou seja, de fatos, que ele afirma estarem ligados ao El-Rei Seleuco, protagonista de sua peça.

Nesse aspecto, há uma postura de parodiar as fronteiras entre História e Ficção, atribuindo o caráter de verdade ou mentira a um elemento de criação ficcional. Observe-se que, nesse ponto, ocorre um processo legitimamente pós-moderno, no sentido definido por Linda Hutcheon em seu livro Poética do Pós-modernismo: história, teoria, ficção, ao afirmar que a paródia é “(...) de forma paradoxal, uma confrontação direta com o problema da relação do estético com o mundo de significação exterior a si mesmo, com o mundo discursivo de sistemas semânticos socialmente definidos (o passado e o presente) - em outras palavras, com o político e o histórico.” (1991, p. 42).

$\mathrm{Na}$ sequência da fala de $\mathrm{CHF}$, há certo tom de pretensa displicência quanto à aprovação popular do que é representado, indicando não se tratar de gosto, mas de uma "verdade". Ironicamente, ao final da cena, CHF é salvo pelas mãos do povo de ser levado à justiça real por aqueles que compreendiam El-Rei Seleuco como uma alusão indiscreta ao casamento do rei D. Manuel com D. Leonor. Pode-se compreender o final da cena como uma metáfora para o modo como CHF será visto em todo o drama: amparado e creditado pelo povo, massacrado pelos poderosos da época. $\mathrm{O}$ fato de a peça ser apresentada por seu próprio autor legitima o caráter valoroso dessa, além de influenciar na receptividade por parte do leitor/espectador.

El-Rei Seleuco, provavelmente escrita em 1545, tem por tema o caso antigo e já narrado por autores clássicos como Plutarco ${ }^{29}$ e João de Barros $^{30}$, da cessão de El-Rei Seleuco de sua jovem esposa, Estratônica ou Estratonice, em favor do príncipe Antíoco, apaixonado pela madrasta e prestes a morrer de amor por ela. Tendo em vista o episódio polêmico que o rei de Portugal protagonizou anos antes, provavelmente este serviu de mote para o resgate da temática do amor proibido entre membros da família real.

\footnotetext{
${ }^{29}$ Nascido por volta de 45 d. C e falecido em torno de 125 d. C. Autor latino de comédias, dentre as quais se destaca a Comédia da Marmita. Disponível em: http://greciantiga.org/arquivo.asp?num=0433. Acesso em: 25 jan. 2015.

30 Homônimo ao historiador, autor de Espelhos casados (1540). Disponível em: http://repositorioaberto.up.pt/bitstream/10216/55944/2/tesemestnellysilva000127745.pdf. Acesso em: 23 jan. 2015.
} 
D. Manuel I, O Venturoso, após perder sua segunda esposa, D. Maria de Aragão, falecida em 1517, encontrava-se em estado de profunda tristeza, quando teria se deparado com o retrato de D. Leonor, irmã de Carlos V (imperador da Alemanha), jovem prometida a D. João III, filho primogênito e sucessor do trono português. O monarca enamorado preteriu o príncipe, casando-se com a rapariga em 1518, vindo a deixá-la viúva em 1521.

Comparando-se as atitudes d'El-Rei Seleuco e do rei D. Manuel, ao contrário do segundo, o primeiro, em virtude do amor que nutre pelo filho, abdica de sua esposa, ao constatar que essa era a "cura" para os males de que padece o príncipe Antíoco, conforme se constata no fragmento abaixo:

\author{
Rei \\ Que mais há que esperar? \\ olhai que estranheza vai \\ o muito amor ordenar: \\ ir-se o filho namorar \\ de uma mulher de seu pai! \\ Querer bem foi sua dor; \\ negar-lhe será crueldade; (...) \\ Ela deixou de reinar \\ como fazia primeiro, \\ por se com êle casar; \\ e por amor verdadeiro \\ tudo se pode deixar. \\ Eu que nela tinha pôsto \\ todo o bem de meu cuidado, \\ deixei mais que ela há deixado; \\ que mais se deixa no gôsto \\ que no poderoso estado. \\ (CAMÕES, 1944, p. 106).
}

A recusa em ceder a esposa em favor do filho é caracterizada como crueldade, já que, segundo El Rei Seleuco, o amor verdadeiro por algo que lhe é caro inclui resignação. Nesse sentido, a personagem se mostra coerente, visto que o sentimento verdadeiro que nutre pela esposa e pelo filho lhe permite abdicar do ser amado. Tecendo o contraponto com o episódio histórico de D. Manuel, esse vê na paixão pela futura nora o remédio para sua tristeza, casando-se com a jovem e preterindo o sentimento filial em favor de sua própria necessidade individual.

A inevitável aproximação entre o episódio histórico ocorrido na Corte Portuguesa e a temática de El-Rei Seleuco gera o descontentamento, representado pelas vozes das personagens do Embuçado (elemento épico) e do Padre (representante da forte religiosidade da época), em oposição ao Homem e à Mulher do povo, que não veem problema na farsa, uma vez que ela estaria representando a realidade conhecida na época. Evidentemente, há aqui a característica de associar 
as personagens mais simples à confusão entre realidade (no sentido de fato histórico) e realidade verossímil, representada no palco. Note-se que os mais agressivos descontentamentos vêm de Embuçados, personagens que têm o rosto tapado como forma de dissimular suas identidades, funcionando tanto como elemento épico em sentido de representar uma coletividade que está fora do texto teatral, quanto para possibilitar sua representação por qualquer ator cuja personagem não esteja em cena:

EMBUÇADO: É uma infâmia falar aqui do casamento de D. Manuel com D. Leonor. (...)

EMBUÇADO: Apanhemos este Camões. Vai prestar contas de sua arte.

OUTRO EMBUÇADO: Vamos ver a valentia desse Trinca-Fortes!

(COSTA, 1982, p. 28-32).

A palavra arte carrega, nesse contexto, a ambiguidade de referir-se à obra camoniana e a ousadia do assunto tratado na peça. Embora não haja comprovações históricas a esse respeito, de que a encenação de El-Rei Seleuco fez uma possível alusão indiscreta ao rei, CH teria sido desterrado para o Ribatejo, possivelmente no ano de 1546 ou 1547, quando frequentava a Corte do Rei D. João III e seus serões no Paço da Ribeira, após ter residido em Coimbra até $1542^{31}$.

Com relação à estrutura, o El-Rei Seleuco de $\mathrm{CH}$ inicia-se com uma espécie de prólogo, que se constitui do diálogo entre o Moço, Ambrósio e Martim, acerca da demora no início do espetáculo, da confusão que houve entre algumas personagens, além da qualidade da peça que será apresentada. O fragmento a seguir reproduz o diálogo entre Ambrósio e o Moço, quando discutem a respeito da origem desse último, após esse fazer uma zombaria quando questionado com relação à demora da apresentação:

Ambrósio:Ó rapaz, não me entendes? Pregunto-te se tardará muito por entrar. Moço:Parece-me, senhor, que antes que amanheça começarão.

Ambrósio:Ó que salgado moço! Zombas de mim? Vem cá, donde és natural?

Moço:Donde quer que me acho.

Ambrósio:Pregunto-te onde nasceste.

Moço: Nas mãos das parteiras.

Ambrósio:Em que terra?

Moço:Tôda a terra é uma; e mais eu nasci em casa assobradada, varrida de aquela hora, que não havia palmo de terra nela.

Martim:Bem varrido de vergonha que me tu pareces. Dize cujo filho és. É para ver com que disparate respondes.

Moço: A falar verdade, parece-me a mim que eu sou filho de um meu tio.

Martim:Vem cá, de teu tio? E isso como?

${ }^{31}$ FIGUEIREDO, Fidelino de. História Literária de Portugal: séculos XII- XX. Rio de Janeiro: Editora Fundo de Cultura, 1960. 
Moço: Como? Isto, senhor, é adivinhação, que vossas mercês não entendem. Meu pai era clérigo, e os clérigos sempre chamam aos filhos sobrinhos; e de aqui me ficou a mim ser filho de meu tio.

(CAMÕES, 1944, p. 54-6).

Em A Viagem - Camões - Poeta prático, a introdução da peça de CHF fica por conta de Estácio da Fonseca, o anfitrião, e o Moço, que, por meio de paráfrases, reproduzem alguns dos diálogos do paradigma de $\mathrm{CH}$, como é possível observar no fragmento a seguir:

ESTÁCIO DA FONSECA: Falta muito para entrarem?

MOÇO: Antes que amanheça hão-de começar.

ESTÁCIO DA FONSECA: És muito gracioso. Zombas de mim? Vem cá, onde nasceste?

MOÇO: Nas mãos das parteiras.

ESTÁCIO DA FONSECA: Em que terra?

MOÇO: Nasci numa casa que tinham acabado de varrer. Não havia nem um grãozinho de areia.

ESTÁCIO DA FONSECA: Varreram-te foi a vergonha. De quem és filho?

MOÇO: A falar verdade, parece-me a mim que eu sou filho de um meu tio.

ESTÁCIO DA FONSECA: Do seu tio? Como é isso?

MOÇO: Como? Isto são coisas que Vossas Senhorias não entendem. O meu pai era padre, e os padres chamam sempre sobrinhos aos filhos, e por isso, eu fiquei filho do meu tio...

(COSTA, 1982, p. 25-6).

$\mathrm{Na}$ análise comparativa entre as peças, pode-se observar que o texto de $\mathrm{CH}$ é retomado, quase que integralmente, na peça de Helder Costa, exceto por algumas modificações vocabulares. Ainda que haja a atualização da linguagem e a simplificação redutora dos diálogos mais extensos, o que está essencialmente em El-Rei Seleuco também está nessa primeira cena, tal como a doença do príncipe Antíoco e a aflição do rei pela saúde do filho, a visita do médico (no original, físico), que diagnostica a paixão pela madrasta como sendo o melindre do doente, a preocupação de Estratonice pelo enteado amado e a cessão, por parte d'El Rei Seleuco, da pretendente, em favor de seu filho por ela enamorado.

O intuito da primeira cena do texto teatral de Helder Costa é representar, ainda que de maneira concisa, o que teria sido a apresentação d'El-Rei Seleuco na época em questão, e, para isso, opta-se, num primeiro momento, por fazer uso do recurso intertextual da paráfrase, já estudado por formalistas russos como Tynianov e Bakhtin, por se constituir como forma de validar um novo discurso, a partir da força dos elementos retomados de um paradigma. O mecanismo parafrásico se caracteriza pela "reafirmação em palavras diferentes, do mesmo sentido de uma obra escrita" (BECKSON, Karl \& GANZ, Arthur. Literary Terms: A Dictionary. Apud SANT’ANNA, 1991, p. 
17) ou ainda na "continuidade ou repetição de uma sentença" (id.ibid., p. 17). Infere-se que há a manutenção da forma e do sentido do que é dito no paradigma, objetivando à valorização do modelo, visto que, por meio da paráfrase, esse se torna mais inteligível e acessível, seja pelo vocabulário mais próximo ao contemporâneo, seja pela sugestão de novos significados não tão evidentes no paradigma. Além disso, ao se realizar a paráfrase, evoca-se para o intertexto a força expressiva do paradigma, embora se acresça a ele outros sentidos, que vêm do contexto e da cosmovisão de quem o relê.

Nesse sentido, cabe trazer à baila a noção de citação de Patrice Pavis, que, segundo ele, consiste em: “(...) efetivamente, retirar um fragmento de texto e inseri-lo num tecido estranho. A citação está ligada, ao mesmo tempo, ao seu contexto original, e ao texto que a recebe. O 'atrito' desses dois discursos produz um efeito de estranhamento". (PAVIS, 2008, p. 48).

Em outras palavras, quando se estabelece o mecanismo de intertextualidade, seja ele paródico, estilizatório ou parafrásico, em última análise, faz-se um "transplante" sutil, parcial ou total do texto paradigmático. O intertexto que recebe o tecido estranho incorpora-lhe. No entanto, esse não é capaz de desvincular o texto "transplantado" de seu tecido original (seu contexto). Daí, cria-se o atrito, ou seja, o efeito de estranhamento.

Embora a paráfrase, como reprodução exata ou atualização de vocabulários mantendo o sentido original, se sobressaia como mecanismo dominante nessa primeira cena, é preciso ressaltar que há momentos de pausa da paráfrase, acompanhados por momentos de intervenção crítica, ao estilo do texto paradigmático. Observe o fragmento, já citado da fala de Estácio da Fonseca, no qual a personagem tenta acalmar alguns espectadores, seguido por algumas falas ao fim da cena, quando a representação se encerra:

ESTÁCIO DA FONSECA: Calma, calma! Nada de irritações! Isto é uma farsa, o nosso amigo Camões não iria meter-se nesses assuntos. Todos conhecemos o perigo que existe em falar das histórias da Corte, e o respeito que devemos a Suas Altezas. (...)

EMBUÇADO: Isso é uma desonra para a Real Família.

HOMEM DO POVO: É mentira o que foi aqui contado?

PADRE: A quem serve falar destas coisas?

MULHER DO POVO: A Vossas Mercês, não serve.

PADRE: A Inquisição saberá ver esta heresia.

(COSTA, 1982, p. 28-32).

Esses são pequenos intervalos dentro da paráfrase do texto de $\mathrm{CH}$. Nos excertos, há a interferência crítica, seja ela conservadora ou não da ordem social em questão, expressa por meio de diálogos opinativos em relação ao que é apresentado. Porém, cabe ressaltar que as pausas imprimem 
ao texto de Helder Costa um sentido extensor do que está tácito no original. Afirma-se, então, que, em meio à constante paráfrase da primeira cena desse ato, há também a presença discreta da estilização, definida como o mecanismo intertextual em que "mantendo em essência a forma do modelo, promove uma inovação, isto é, uma transformação do ou no conteúdo do modelo, sem negá-lo ou opor-se a ele, trazendo-lhe à tona o que lhe está implícito.” (CORRADIN, 1998, p. 36).

Helder Costa mantém o estilo de CH d'El-Rei Seleuco durante toda a cena, embora acresça sugestões de sentido crítico à paráfrase, conserva o aspecto singular da reprodução fiel do texto de $\mathrm{CH}$, inserindo, porém, um novo desdobramento a ele, ao estilo do texto paradigmático, que pertence ao intertexto. Nomear-se-á tal procedimento intertextual de paráfrase estilizadora, para se referir à estilização que ocorre nos intervalos de uma longa paráfrase, de modo a sugerir e incorporar ao intertexto uma mudança no conteúdo, embora ainda se mantenha a forma do que é parafraseado.

O texto de A Viagem - Camões - Poeta prático não se limita apenas a repetir paradigmas, mas sim a utilizar-se deles como ponto de partida para a construção de uma nova visão acerca do tema tratado. A adoção desse mecanismo funciona dentro da peça como uma mola propulsora de referências, tanto históricas quanto literárias, que, aos poucos, vão se chocando, entrecruzando-se, criando, em última análise, uma espécie de "labirinto de referências" 32 em que se desenvolvem os diálogos ficcionais. Essa característica é essencial para a (re)construção de um novo CHF, sugerido no título da peça A Viagem - Camões - Poeta prático, visto que a paráfrase é um meio de reforçar a construção de CHF, de modo a situar o leitor no contexto histórico, político e social da época, relacionando-os diretamente com a produção do poeta português, personagem histórica de quem se tem poucos dados comprovados a respeito.

Tendo em vista a possibilidade de "preencher" com sua cosmovisão esses espaços, Helder Costa faz surgir CHF, imbuído de força histórico-artística, na medida em que carrega em si o contexto histórico a que pertenceu, bem como o peso de suas produções literárias. Tal figura dramática é revestida por grossa camada de ficção, em uma composição que combina informações imprecisas acerca do poeta português, especulações e, claro, a visão do autor. O resultado é uma personagem fortemente verossímil dentro da proposta sugerida no título A viagem - Camões Poeta prático, cujo ponto basilar está na suposição de o autor d'Os Lusíadas ter escrito sua epopeia a partir das experiências práticas que teria vivido, considerando o que se sabe a respeito.

Afirma-se que a vida imita a arte; porém, no caso dessa peça teatral, a representação artística advém da ficcionalização de uma vida. A releitura sugere a inseparabilidade entre as experiências

\footnotetext{
${ }^{32}$ Utiliza-se esse vocábulo com sentido aproximado ao termo "mosaico de citações”, referido por Julia Kristeva (1979), ao definir intertextualidade.
} 
individuais do ser e a maneira como essas são transformadas em obras de arte, por conseguinte, fazendo com que o espectador repense a transformação do ser em agente da História.

\subsection{Cena II - Ato I - O Mal-Cozinhado ${ }^{33}$}

Após a conturbada cena anterior, na qual CHF é atacado por descontentes espectadores da encenação de El-Rei Seleuco, em virtude da possível alusão que essa fazia ao casamento do rei D. Manuel e sua terceira esposa, D. Leonor, o vate escapa, pela proteção popular, da casa de Estácio da Fonseca e refugia-se no Mal-Cozinhado.

O lugar teria sido assim nomeado pelo poeta, conforme se infere do excerto retirado da Carta III do bardo a um conhecido de Lisboa:

(...) De algüas conseguintes vossas amigas vos darei novas. Maria Caldeira matou-a o marido. Grande perda para o povo, porque reparava muitas órfãs e adubava os pagodes de Lisboa, afora outras obras de grandes respeitos. E, por que esta senhora não vivesse muito tempo no outro mundo só, se partiu para lá Beatriz da Mota, vossa amiga.

Deste dilúvio houveram algüas destas damas medo e edificaram üa torre de Babilónia, onde se acolheram; e vos certifico que são já as línguas tantas, que cedo cairá, porque ali vereis mouros, judeus, castelhanos, leoneses, frades, clérigos, casados, solteiros, moços e velhos.

A esta torre chamaram Acolheita, pela fortaleza dela. Mas o filósofo João de Melo lhe pôs nome o Rompeu, porque é de três paus, a saber: de Francisca Gomes, a Tarifa, e Antónia

Brás, afora a bola, que é Maria da Rosa . Eu o crismei há poucos dias e lhe pus o nome de Mal-Cozinhado, porque sempre achareis nele que comer, quer bem, quer mal. E tudo o destas senhoras é brando, rostos novos e canos velhos. São boas para ninfas de água, porque não deitam mais que a cabeça de fora.

A razão por que se comem estas mais que as outras em

Lisboa, é que, afora seus rostinhos, servem de foliões, que cantam e bailam tão bem que não hão inveja aos que El-Rei mandou chamar. ${ }^{34}$

A carta é iniciada com notícias de Maria Cladeira e Beatriz de Mota, cujas mortes causaram espanto em outras mulheres que se reuniram num novo lugar, a Torre de Babilônia. Subentende-se que eram prostitutas e que, em virtude de suas mortes, as demais procuraram um novo espaço, frequentado por mouros, judeus, castelhanos, leonenses, frades, clérigos, casados, solteiros, moços e

\footnotetext{
${ }^{33}$ Trata-se de um bordel que teria sido frequentado por $\mathrm{CH}$.

${ }^{34}$ Disponível em: http://www.jornaldepoesia.jor.br/camoes148.html Acesso em: 25 jan. 2015.
} 
velhos, ou seja, todo o tipo de gente. Um dos amigos de $\mathrm{CH}$, João de Melo ${ }^{35}$, que aparece na segunda cena da peça, teria nomeado o lugar de Rompeu, devido a três figuras femininas que ali habitavam. Já o poeta português prefere o título de Mal-Cozinhado, em virtude da qualidade das prostitutas do lugar, atribuindo-lhes alto valor em comparação a outros bordéis e festas palacianas. Ao comparar a qualidade das prostitutas do alcoice àquelas que participavam das festividades promovidas pela Nobreza, o vate configura-se como autoridade na matéria em questão e possível frequentador de ambos os espaços, na medida em que garante que as mulheres do Mal-Cozinhado são muito procuradas, não devendo nada às contratadas pela Corte.

Jorge de Sena (2006) analisa algumas das correspondências camonianas (personagem histórica) e afirma que as alusões feitas pelo poeta português remeteriam a um profundo conhecimento da vida boêmia lusitana, sendo esse um contundente indício para auxiliar na composição da, ainda obscura, biografia do compositor de Os Lusíadas.

Tendo o bordel por ambiente principal da segunda cena, a caracterização de CHF passa a adquirir novos contornos, sendo o poeta visto não apenas como dramaturgo que produz trabalhos grandiosos e os apresenta em espaço privado, como a casa de Estácio da Fonseca, mas também como assíduo visitante do prostíbulo, cujas produções artísticas são conhecidas pelos demais frequentadores do bordel. O professor Massaud Moisés trata a respeito dessa particularidade na introdução da Lírica:

(...) De um lado, a amizade com certos representantes da nobreza, D. Antônio de Noronha, João Lopes Leitão, D. Simão da Silveira. De outro, a estúrdia, a frequiência perigosa do bas-fond lisboeta. De vida incerta, fatalmente se meteria por vêzes, em desregramentos e brigas que o confundiriam com o mundo de jograis do povo, rameiras e malandros. Logo um apelido the é dado: o "Trinca-fortes", e assim ficou. (1976, p. 11).

Embora o intuito da peça de Helder Costa não seja a veracidade da biografia de $\mathrm{CH}$, mesmo porque há mais especulações do que fatos comprovados a respeito, a caracterização dessa personagem reproduz a ambiguidade que parece ter sido real em vida. Atendendo à descrição anterior, o CHF de A Viagem - Camões - Poeta prático é um sujeito libertino, briguento, desregrado, conquistador, arauto notável, que circulava tanto entre a mais alta Nobreza quanto em meio a pessoas simples que frequentavam a boemia lisboeta.

\footnotetext{
${ }^{35}$ Personagem histórica que teria sido amiga próxima de Camões. Segundo o vate, seria o autor da alcunha Rompeu, que remete ao bordel Mal-Cozinhado, que supostamente ambos frequentavam.
} 
A segunda cena do ato se inicia com a fala de Antónia Brás, prostituta que recita alguns versos, sendo acompanhada em coro pelos frequentadores do bordel, conforme se pode constatar no fragmento abaixo:

\author{
ANTÓNIA BRÁS: Vós sois uma dama \\ Das feias do mundo; \\ De toda a má fama \\ Sois cabo profundo. \\ A vossa figura não é para ver; \\ Em vosso poder \\ Não há formosura. \\ TODOS: Vós fostes dotada \\ De toda a maldade; \\ Perfeita beldade \\ De vós é tirada. \\ (COSTA, 1982, p. 34).
}

No excerto, nota-se o emprego de outro recurso intertextual que não a paráfrase, predominante na cena anterior: a paródia. Considerada a esfera em que repousa o vitupério e a crítica com fins de emulação, esse recurso tem por característica fundamental a manutenção da forma do paradigma, no caso a de $\mathrm{CH}$, associada ao derrisório conteúdo que lhe compõe. Analisando o excerto, verifica-se que a forma do texto paradigmático (as redondilhas camonianas) é mantida integralmente, com pequenas atualizações na linguagem, sendo a mudança mais significativa legada ao plano do conteúdo.

Os versos camonianos, frequentemente associados à representação do amor elevado, são recitados em um bordel, por uma prostituta, caracterizada com vulgaridade na cena, sendo acompanhada em coro pelos frequentadores do lugar. Antónia Brás não declama os versos com a finalidade de lhes evidenciar a beleza ou elogiar alguém, porém meramente como distração para os homens ali presentes, ao que é acompanhada por um coro de vozes, indicando que se trata de um hábito a declamação dos versos de CHF no bordel. Na sequência, o próprio CHF se junta ao coro do lupanar, encerrando a recitação de seus versos ao receber em seus braços a concubina.

O formato da declamação feita pela marafona, em forma de diálogo entre o que ela recita e o que a plateia em coro responde, sugere, ainda que brevemente, a evocação dos coros da tragédia grega clássica, arte destinada a tratar de elevados assuntos, relacionada a seres superiores, tais como deuses, semideuses e reis. A presença de um coro, ainda que formado por personagens baixas ${ }^{36}$,

\footnotetext{
${ }^{36}$ Emprega-se o termo personagens baixas a partir do pressuposto da tragédia aristotélica, no qual “(...) define-se a comédia por três critérios que se opõem à tragédia: suas personagens são de condição modesta, seu desenlace é feliz e sua finalidade é provocar o riso no espectador." (PAVIS, op. cit. p. 52-3).
} 
evidencia um diálogo paródico com as tragédias gregas clássicas, nas quais o coro ocupava papel de destaque no canto de partes significativas do drama representado ${ }^{37}$, de modo a intermediar a ação dos atores e os pensamentos que eram suscitados na plateia, por vezes tornando-se, o próprio coro, um espectador ideal que moderava os discursos representados. Dessa feita, há uma dissonância entre a matéria tratada nos versos e as personagens que a representam ${ }^{38}$.

Considerando que os versos são cantados por seres marginais daquela sociedade, evidenciase a paródia: "um texto que contém outro texto em si; do qual ela é a negação, uma rejeição e uma alternativa" (KOTHE, Flávio R. Paródia \& Cia. In: Sobre a paródia. Apud CORRADIN, 1998, p. 32), ou seja, o coro, originalmente trágico, sofre um rebaixamento, visto que é integrado pelos socialmente excluídos, causando uma inversão de valores, que resulta em efeito cômico, rebaixador. Na cena mencionada, o coro não tem por finalidade convidar à reflexão, porém objetiva inverter valores, rebaixando-os ao torná-los parte do que há de mais repudiado na sociedade da época: um lupanar. O recurso paródico com vistas ao rebaixamento de um modelo ganhará espaço ao fim da cena, quando, em coro, todos recitam novamente a redondilha camoniana.

No que tange ao ambiente, é estabelecido um contraponto entre a casa de Estácio da Fonseca, homem de prestígio na época, que cedia sua residência para apresentações artísticas que considerava valorosas, em oposição ao Mal-Cozinhado, ambiente sórdido, que não selecionava o seu público, sendo frequentado por personagens polêmicas, como o padre Chiado $^{39}$, particularmente gerador de antipatia dos poderosos do período.

Terminada a "apresentação" das redondilhas camonianas, a conversa gira em torno da confusão que o espetáculo El-Rei Seleuco gerou. Mais uma vez, CHF não deixa claras as intenções de sua peça, como é possível notar em dois excertos da cena:

UM JOGADOR DE CARTAS - Então, o nosso escudeirote Camões, meteu-se em cavalarias altas?

CAMÕES - Só os maldizentes é que me acusam disso. (...)

\footnotetext{
${ }^{37} \mathrm{O}$ coro na tragédia aristotélica tinha por função a tessitura de comentários acerca da ação que era representada, por vezes, tomando partido do coletivo, dialogando com o herói ou ocupando o interlúdio das ações do mesmo. Por outro lado, se o coro aparece em um texto teatral épico, em sentido de assumir um caráter didático e político, este reproduz a voz do autor, ou, ainda, a voz do povo, mediada pelo autor. (ROSENFELD, 2006).

${ }^{38} \mathrm{Na}$ tragédia, as personagens eram elevadas e, por consequência, o assunto tratado também o era, ao passo que, na comédia, o espaço pertencia às personagens baixas e a assuntos inferiores. (ARISTÓTELES, 1981).

${ }^{39}$ Provável referência ao poeta António Ribeiro (? - 1591), nascido em Évora, que teria ganhado a alcunha, vinda do termo asiático chiado, em virtude dos autos maliciosos que escrevia. Padre ordenado, o rapaz teria abandonado o monastério por força da vida desregrada que levava. Seu estilo de escrita assemelha-se ao de Gil Vicente, produzindo autos que descrevem, com minúcia de detalhes, os costumes e vícios do século XVI.

Disponível em http://www.lisboapatrimoniocultural.pt/artepublica/eescultura/pecas/Paginas/Chiado.aspx. Acesso em: 25 jan. 2015.
} 
PADRE CHIADO - Mas, diz-me, Luís Vaz, a farsa era mesmo para troçar de ElRei?

CAMÕES - Uns vão dizer que sim, outros vão dizer que não...

(COSTA, 1982, p. 36-8).

A constante recusa do bardo em definir a intenção de sua obra acresce caráter dúbio a suas ações, característica essencial para reforçar a verossimilhança da personagem no texto teatral de Helder Costa. $\mathrm{Na}$ ambiguidade está a chave de leitura proposta pela peça.

No excerto citado, a personagem do padre Chiado aparece como umas das que provocam CHF acerca da complicada situação em que se encontra após a fuga para o Mal-Cozinhado. Francisca, outra rameira, desqualifica o padre, rememorando-o de sua conduta pouco digna para um sacerdote, dado que está em um bordel, cercado de marafonas e a pecar desenfreadamente, como é exemplificado no fragmento abaixo:

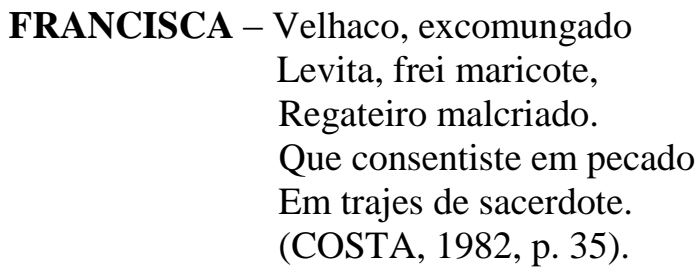

A figura de Chiado, assim caracterizado como um padre indigno da posição de privilégio que ocupa, rememora a personagem estereotipada do sacerdote de $O$ auto da Barca do Inferno, de Gil Vicente. Tanto Chiado quanto o padre do auto compartilham da imoralidade e promiscuidade em seus atos. Os fragmentos a seguir, retirados da obra de Gil Vicente e do texto teatral de Helder Costa, comprovam a conduta reprovável de ambos:

DIABO Que é isso, padre?! Que vai lá?

FRADE Deo gratias! Sou cortesão.

DIABO Sabês também o tordião?

FRADE É mal que me esquecerá.

DIABO Essa dama há de entrar cá?

FRADE Não sei onde embarcarei.

DIABO Ela é vossa?

FRADE Não sei;

Por minha a trago eu cá.

DIABO E não vos punham lá grosa

nesse convento sagrado?

FRADE Assim fui bem açoitado.

DIABO Que cousa tão preciosa! Entrai, padre reverendo.

(VICENTE, 2006, p. 84). 
PADRE CHIADO - Julga um padre encontrar a palavra de Deus com esta gente... é só pecado, e pouca vergonha.

(Gargalhadas. Chiado bebe e abraça-se à Luísa $\left.{ }^{40}\right)($...)

CHIADO: Luísa, tu te avisa

Que tais melões lhe não dês,

Porque esse que aí vês

Trinca-Fortes mala guisa.

(Todos brincam com a alusão aos seios de Luísa. Bebem e comem).

(COSTA, 1982, p. 35-8).

Ambas as personagens agem de maneira contrária ao que se espera de membros do clero, sendo, por isso, condenadas ao inferno ou vistas como escória. Chiado é um antimodelo eclesiástico, logo é inferiorizado quando comparado a CHF ou aos demais frequentadores do bordel.

A ideia de que a sociedade possa ser dividida entre os dignos e os desprezíveis encontra espaço na conversa entre Estácio da Fonseca, o bispo e Duarte Rodrigues ${ }^{41}$, quando discutem as consequências que adviriam da encenação da farsa de CHF:

ESTÁCIO DA FONSECA - Mas não acredito que Camões quisesse injuriar a Corte. Ele sabia os perigos que poderia correr. E é uma história antiga, que já nem tem interesse.

BISPO - Esse Camões é um ser sem vergonha, e um ingrato em relação à nobreza que o podia ajudar. Pior que o Chiado. Da mesma laia de Gil Vicente.

DUARTE RODRIGUES - Esses homens das letras não respeitam o poder de quem manda. Querem acusar tudo, querem zombar de tudo.

(COSTA, 1982, p. 37).

O substantivo "laia" alude a uma classe de pessoas que eram vistas como prejudiciais ao status quo da época, visto que apresentavam em seus escritos temas polêmicos, que criticavam a deterioração moral daquela sociedade, representando, por isso, uma afronta aos que detinham o poder. Enquanto Gil Vicente repudiava os tipos viciosos da sociedade lisboeta, considerando-os responsáveis pela degradação de valores, CHF "troça" do episódio ocorrido na Corte Manuelina e Chiado maldiz o que não aprecia. A crítica à sociedade a que pertenciam, embora nem sempre com o intuito de confrontar a ordem estabelecida, é um traço comum a essa "laia" de homens das letras, que não respeitam o poder de quem manda. CHF é qualificado como devasso, libertino, imoral,

\footnotetext{
${ }^{40}$ A personagem é caracterizada como uma prostituta na peça.

${ }^{41}$ Enteado de Estácio da Fonseca, ocupava o cargo de reposteiro da casa real, espécie de funcionário responsável por servir a mesa do rei.
} 
descrente e até mesmo cristão-novo ${ }^{42}$, cuja ingratidão o afasta da benevolência da Nobreza que o poderia ajudar.

A esse respeito, padre Chiado o aconselha a pedir proteção a uma das damas que apreciam sua arte, referindo-se aos envolvimentos amorosos ${ }^{43}$ que o vate teria tido com nobres damas da Corte, dentre as quais se destaca a Infanta D. Maria, irmã de D. João III. O termo "cavalarias altas", dito por um dos frequentadores do Mal-Cozinhado ao referir-se à ousadia do poeta em sua peça, pode ser compreendido também como uma alusão à tentativa de CHF em alçar voos mais altos do que o permitido para sua posição social. A fama de galanteador será tratada com maiores detalhes na cena subsequente, quando o poeta pedirá proteção a D. Violante.

\subsection{Cena III - Ato I - Camões pede protecção a D. Violante ${ }^{44}$}

$\mathrm{Na}$ primeira cena desse ato, notou-se a composição de CHF com base em aspectos relacionados a ele como autor, especialmente como escritor da farsa que possivelmente aludia ao rei D. Manuel. Porém, a cena subsequente ocupa-se em acrescer ao protagonista outras características, que não apenas o valorizem como arauto, porém que tragam à baila o poeta boêmio, frequentador de bordeis e, por consequência, um libertino. Ainda sob o efeito caleidoscópico da composição fragmentária da personagem central da peça, a terceira cena enfoca o pedido de proteção que CHF dirige a D. Violante, que, por pertencer à Nobreza, poderia lhe oferecer tutela diante das consequências que adviriam da apresentação de El-Rei Seleuco. Traçando um contraponto ao pedido de proteção, surge a figura do marido de D. Violante, D. Fernando de Noronha ${ }^{45}$, que exige justiça diante da desonra feita por CHF à sua casa.

A fama de galanteador atribuída ao bardo não é inovação da peça em questão. Ao contrário, por longo tempo, biógrafos do vate tomaram seus poemas líricos como base de especulação acerca de seus relacionamentos amorosos. No que concerne à sua reputação de conquistador, o professor Massaud Moisés afirma no prefácio da Lírica, de Luís Vaz de Camões, que se trata de um homem “(...) talentoso e culto enquanto poeta, ardente enquanto homem, era natural que Camões tivesse levado à paixão qualquer dama da Corte, e, por isso, provocado ciúme aos fidalgos e pares concorrentes aos mesmos favores" (1996, p. 10.). Rumores acerca de seus relacionamentos amorosos povoam o imaginário popular, envolvendo desde as altas cavalarias como a Infanta D.

\footnotetext{
${ }^{42} \mathrm{O}$ termo foi cunhado para diferenciar os cristãos dos judeus convertidos à força durante o governo de D. Manuel como condição para que pudessem permanecer nos país.

${ }^{43}$ Não há documentos históricos que comprovem quaisquer suposições acerca do tema.

${ }^{44}$ Possível alusão à condessa D. Violante, a quem, segundo Joaquim Veríssimo Serrão, em História de Portugal (1996, p. 388 v. 2) Camões atribuiu seus infortúnios.

${ }^{45}$ Possível alusão ao nobre que $\mathrm{CH}$ teria estado a serviço, D. Francisco de Noronha, casado com D. Violante. (SARAIVA, 1978).
} 
Maria, irmã do rei D. João III, D. Violante, até a desconhecida ou lendária mulher que teria morrido afogada, ao ser preterida pelo vate, que salvou seu poema épico Os Lusíadas em um naufrágio.

Na peça, a personagem de D. Violante é retratada como sendo casada com o nobre D. Fernando de Noronha, a quem $\mathrm{CH}$ teria prestado serviço desde jovem ${ }^{46}$.

A cena é iniciada com a reclamação de CHF a respeito da mesmice da função de escrever versos por dinheiro, indicando certa nostalgia da vida que levava quando esteve ligado aos Noronha, conforme deixa patente o excerto:

CAMÕES - Estou sempre na mesma. Desde que saí desta casa, ganho uns cobres a escrever petições, trovas de amor, o costume.

FRANCISCO DE MORAIS ${ }^{47}$ - Os fidalgos são bons fregueses, gostam de mostrar "arte e engenho".

(COSTA, 1982, p. 39).

O versejar é tido como algo cotidiano para o poeta, porém de extrema valia para os fidalgos, que apreciam o engenho e a arte e o pagam para que escreva. Tanto CHF quanto Francisco Morais troçam dessa necessidade da fidalguia em demonstrar grandiloquência, especialmente quando é preciso pagar para obtê-la.

Ao encontrar D. Violante, o bardo coloca-se em posição semelhante ao trovador de cantigas amorosas, vassalo de sua amada, porém, ao que se depreende da cena, sua postura advém do fato de o poeta ter cortejado a filha de sua dama, traindo-a. O recurso paródico novamente se faz presente nessa cena, visto que os valores do amor servil, leal, submisso, não correspondido, do ideário medieval, são subvertidos pela consumação do amor, pela traição e, até mesmo, pelo interesse que move o poeta a aproximar-se da dama. No entanto, D. Violante evidencia a distância hierárquica social entre eles, quando responde às declarações de amor de $\mathrm{CHF}$, como é possível notar no excerto:

CAMÕES - Eu amo-te, Violante. Desejo-te.

VIOLANTE - Os criados não podem brincar com seus donos. Tu fazes pequenos versos inúteis, sobre os cabelos, o olhar, o corpo das damas da Corte por quem tu te humilhas, rastejando.

CAMÕES - Violante, o nosso amor...

VIOLANTE - Tu amoroso? Sugaste o meu amor, e deixaste-me fria e seca. Não te chegou. Cortejaste minha filha, para chegares aos pés de El Rei.

CAMÕES - Eu amei a tua filha Joana ${ }^{48}$.

\footnotetext{
${ }^{46}$ Tal hipótese já foi mais bem elucidada no capítulo anterior, no qual se tratou da vida de $\mathrm{CH}$.

${ }^{47}$ Possivelmente um poeta contemporâneo a $\mathrm{CH}$.

${ }^{48}$ Joana é filha de D. Violante e Francisco de Noronha, patrões de $\mathrm{CH}$.
} 
VIOLANTE - Nunca terás a minha filha. Agora, conta com o meu orgulho e o meu ódio. Os escudeiros não humilharão nunca a minha linhagem.

(COSTA, 1982, p. 40).

A paródia é levada às últimas consequências como recurso subversivo quando a personagem feminina ridiculariza os versos de $\mathrm{CH}$ e eventuais sentimentos ali contidos, rebaixando-o de conquistador à posição de homem comum. Ao silenciá-1o ${ }^{49}$, humilha-o, tornando-o uma espécie de Don Juan falho.

Novamente, a cena propõe a configuração de CHF como poeta à luz de seus contemporâneos. Diálogos ficcionais entre personagens históricas, tais como D. Fernando de Noronha, D. João III, Pedro Andrade de Caminha ${ }^{50}$ emitem juízos de valor acerca do bardo:

D. FERNANDO DE NORONHA - Alteza! O meu criado Luís Vaz de Camões quis ultrajar a honra da minha casa, requestando a minha filha Joana.

D. JOÃO III - Um criado que quer chegar a fidalgo, Ah!Ah!Ah!

BISPO - É necessário agir imediatamente. Temos de vingar a honra ultrajada do nosso Rei, com esta farsa chamada El-Rei Seleuco.

DUARTE DE FIGUEIREDO - Far-se-á justiça (...)

PEDRO ANDRADE DE CAMINHA - (...) Esse Camões, poeta menor, notório libertino e hereje, ofende a honra da nossa melhor fidalguia, espalhando a fama de ser amante da esposa de D. Fernando de Noronha.

(COSTA, 1982, p. 41).

A fala de Pedro Andrade de Caminha, rival de CHF, traça um paralelo entre as concepções que ambos tinham acerca da fidalguia: um a via como aliada, enquanto o autor d'Os Lusíadas zombava de seus costumes, como foi mencionado anteriormente, no início da cena.

Observa-se, mais uma vez, que o abismo social entre CHF e a Nobreza é evidenciado, inclusive por meio da relação serviçal, que é enfatizada na peça. A ideia de ir às cavalarias altas aparece não só em referência à alusão que sua peça El-Rei Seleuco teria feito ao rei, mas também remete ao envolvimento amoroso de $\mathrm{CHF}$ com nobres damas da Corte. $\mathrm{CH}$ teria sido desterrado em 1548, supostamente devido à alusão indiscreta ao rei em sua farsa e às desavenças entre o poeta e o marido de D. Violante, D. Francisco de Noronha.

Ao fim da cena, estão esboçadas as características que permitem a Helder Costa dar forma ao CHF antes de sua viagem. Vale notar o caráter contraditório do poeta: amado, criticado, invejado, desleal, interesseiro, tentado a buscar as cavalarias altas. É em meio a esse caleidoscópio de imagens construídas a partir da fusão de fatos históricos e à cosmovisão de Helder Costa, que

\footnotetext{
${ }^{49}$ A personagem só volta a falar no fim da quarta cena.

${ }^{50} \mathrm{O}$ nome correto da personagem histórica referida é Pedro de Andrade Caminha, poeta português que teria sido rival de Luís Vaz de Camões.
} 
surge um novo CHF, senhor de sua experiência prática da Viagem, de suma importância para a composição da obra que o tornaria célebre.

\subsection{Cena IV - Ato I - Na prisão do Tronco}

No que concerne ao desterro de $\mathrm{CH}$, acredita-se que tenha ocorrido entre 1547 e 1548, como punição tanto pela alusão indiscreta ao rei na farsa El-Rei Seleuco ${ }^{51}$, quanto pelo suposto envolvimento amoroso do poeta com damas da Alta Nobreza, referidas na peça como altas cavalarias, dentre as quais estaria, supostamente, D. Violante.

A quarta cena da peça, intitulada $\mathrm{Na}$ prisão do Tronco, trata do encarceramento de $\mathrm{CHF}$ após a recusa de D. Violante em protegê-lo dos perseguidores descontentes com a apresentação de El-Rei Seleuco. Como se pode observar em excerto retirado da cena anterior:

D. FERNANDO DE NORONHA - Alteza! O meu criado Luís Vaz de Camões quis ultrajar a honra da minha casa, requestando a minha filha Joana.

D. JOÃO III - Um criado que quer chegar a fidalgo, Ah! Ah! Ah!

BISPO - É necessário agir imediatamente. Temos de vingar a honra ultrajada do nosso Rei, com essa farsa chamada El Rei Seleuco.

(COSTA, 1982, p. 41).

O poeta embarca para Ceuta como militar e regressa anos mais tarde com sequela permanente adquirida em combate: a perda do olho direito. Não é possível precisar o tempo em que esteve ausente de Portugal. No entanto, não existem rumores de sua presença no país pelos dois anos seguintes a seu embarque. Desprovido de recursos quando retornou à sua terra natal, $\mathrm{CH}$ teria se alistado como soldado em 1550, sem, no entanto, embarcar de fato. Levando uma vida boêmia e pouco regrada, o bardo teria ganhado a alcunha de o Trinca-Fortes $^{52}$, em virtude de seu constante envolvimento em conflitos. No ano de 1552, no dia da procissão de Corpus Christi, envolveu-se em briga com o moço do paço ${ }^{53}$, Gonçalo Borges, imortalizado pela cutilada que recebera do vate. $\mathrm{O}$ resultado da contenda foi seu encarceramento na prisão do Tronco $^{54}$ e posterior perdão real $^{55}$ do incidente, em troca do imediato embarque do agressor rumo às Índias.

\footnotetext{
${ }^{51}$ Hipótese já discutida durante a análise da primeira cena deste ato.

${ }^{52} \mathrm{Na}$ peça de Helder Costa, o apelido Trinca-Fortes é mencionado antes mesmo de seu desterro, sugerindo que seu comportamento desregrado já era bastante conhecido por todos.

${ }^{53}$ Funcionário que prestava serviço no palácio real.

${ }^{54}$ A prisão do Tronco era destinada a abrigar pessoas de classes sociais mais baixas, sendo um dos indícios que confirma a origem mais humilde do poeta.

${ }^{55}$ A carta de perdão real, datada de 1553, é o primeiro documento que se tem acerca de Luís Vaz de Camões.
} 
Observe-se que CHF é levado para a prisão do Tronco antes de seu desterro para Ceuta e, segundo fragmento retirado da fala do narrador, o poeta será novamente enviado em outro momento para a mesma cadeia:

NARRADOR (ou voz - off) - Enquanto Camões anda em bolandas e peripécias, que o levam a Ceuta, onde ficará cego de um olho, que o encerrarão novamente na prisão do Tronco, a vida da Corte continua doce e suave...

(COSTA, 1982, p. 46).

O narrador, que é por excelência um recurso épico, demonstra, por meio da ironia, a contraposição entre a Prisão do Tronco e a doce vida da Corte, com a intenção de despertar o público de uma possível identificação que possa ocorrer durante a representação. Valendo-se da supressão histórica, o narrador relata de maneira breve os acontecimentos envolvendo o poeta, sugerindo repetição das prisões de $\mathrm{CHF}$. Ao que se sabe, $\mathrm{CH}$ esteve preso uma única vez na prisão do Tronco, de onde saiu após a carta régia de perdão, embarcando imediatamente para as Índias. O aparente anacronismo pode ser justificado se for considerado como um indicativo proposital de que CHF iniciou sua "experiência prática" na prisão destinada aos criminosos de origem plebeia e, em função disso, teve contato com o aspecto cruel da realidade daqueles que não pertenciam ou não estavam ligados à Nobreza.

Os termos "bolandas" e "peripécia", ditos pelo narrador ao final da cena, remetem ao modelo aristotélico da tragédia grega, na qual o herói trágico:

(...) é aquele que nem sobreleva pela virtude e justiça, nem cai se cai no infortúnio, em conseqüência de vício e maldade, senão de algum erro, figurando entre aqueles que desfrutam grande prestígio e prosperidade (...) passar, não do infortúnio à felicidade, mas, ao contrário, da felicidade a infortúnio que resulte, não de maldade, mas dum grave erro de herói (...). (ARISTÓTELES, 1981, p. 32).

Embora o conceito de peripécia remeta, em primeira instância, ao conceito aristotélico de "mudança súbita e imprevista da situação, reviravolta ou “inversão da ação"” (PAVIS, 2008, p. 285), o termo é empregado no texto de Helder Costa com seu sentido moderno, que consiste em designar os altos e baixos de uma ação.

Ainda que o narrador aproxime os infortúnios sofridos por CHF aos dos heróis da tragédia clássica, ocorre a subversão desses valores, visto que o poeta não pertence à Nobreza nem se distingue por suas qualidades valorosas, mas está preso por supostos envolvimentos com damas da Corte, além de sua alusão indiscreta à figura do Rei. 
A cena pode ser dividida em dois momentos; o primeiro deles destinado a contextualizar a atmosfera da prisão, na qual há a supervalorização do dinheiro, da violência e da crueldade, representada por meio das torturas destinadas aos presos e, na sequência, CHF é inserido nesse mesmo ambiente prisional, ressaltando a evidente oposição entre os acontecimentos desventurosos relativos ao poeta e a aparente facilidade da vida na Corte.

As condições precárias da cadeia estão presentes em todos os momentos da cena, desde o oferecimento de comida condicionada ao seu pagamento, até o roubo praticado pelo carcereiro. Observe os fragmentos a seguir, retirados da cena:

MULHER - (Batendo com uma colher num tacho) - Quem quer comer? Ninguém tem fome?

PRESO 1 - Eu...eu...

MULHER - São 40 reais...

PRESO 2 - É caro.

MULHER - Queriam estar aqui e serem bem tratados, é?

(...) (A violência deve ir crescendo)

PRESO 4 - Roubaram-me! Roubaram-me!

GUARDA (Correndo) - Quem foi? Quem foi?

PRESO 4 - Não sei. Se calhar foi aquele. (Aponta para outro preso).

GUARDA - (...) Então, vamos lá a mostrar o dinheiro que roubaste àquele. (...) Se não fizeste agora, fizeste há mais tempo.

PRESO 5 - Está aqui o dinheiro. Tinha fome.

(Guarda tira-lhe o dinheiro. Empurra-o para a zona de tortura ao fundo. Dirige-se ao preso 4)

GUARDA - Então disseste que aquele te tinha roubado dinheiro.

PRESO 4 - Pareceu-me. Talvez fosse...

GUARDA (Bate-lhe) - Não sabes que isso não se faz? Não sabes que não podes acusar um preso, sem teres certeza? Não sabes que vocês nos fazem perder a paciência?

(Acaba por empurrá-lo para a zona de tortura.)

(COSTA, 1982, p. 44-5).

A personagem do guarda representa a força bruta, que predomina no ambiente carcerário, em oposição aos presos, que se mostram intimidados com o comportamento agressivo do representante da justiça. Percebe-se, pois, que os presos são tratados com violência e crueldade, de modo a destituí-los da condição de seres humanos, equiparando-os a escravos. A mulher bate com a colher no tacho, como faria para chamar a atenção de animais, o guarda rouba dos presos e os tortura, no entanto exige dos detentos a consciência de que não podem acusar uns aos outros sem provas. O espaço da prisão do Tronco é caracterizado pela sujeira, tanto moral quanto física, além da distorção constante do conceito de justiça, uma vez que seus representantes usam-na para aplicar a lei do mais forte, estimulando a crescente atmosfera violenta. Prevalece na cena a representação de um ambiente tomado pela corrupção e hipocrisia, advindas das figuras que deveriam representar 
a ordem, e não sua subversão. É nesse ambiente inóspito e pouco inspirador que o CHF parece resignado e alheio ao que o cerca, demonstrando, até mesmo, certo pesar pelas faltas cometidas:

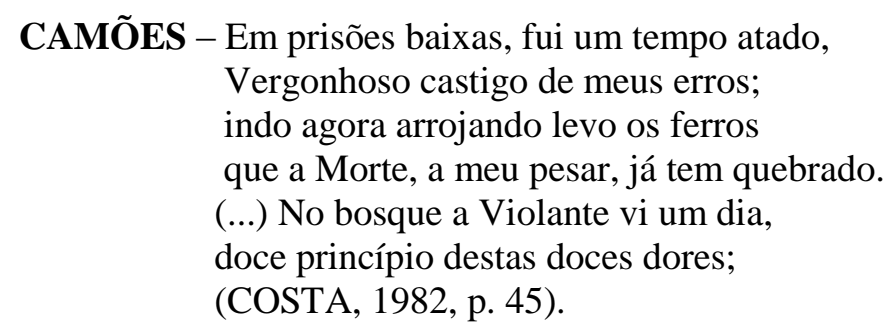

CHF parece ocupar-se de reminiscências acerca do início de seu envolvimento amoroso com D. Violante e aludir seus infortúnios, ao envolvimento com a dama. A submissão à condição em que se encontra é expressa no diálogo entre o vate e um amigo que estaria preso com ele, indicando que não haveria nada além da aceitação do que lhe é imposto.

Outro aspecto significativo nesse diálogo é o que envolve o valor da escrita, quando o poeta pergunta se o amigo gostaria de aprender a ler e escrever e obtém como resposta o questionamento a respeito da utilidade de se saber tais coisas: "Isso serve para alguma coisa?" (COSTA, 1982, p. 45). Tal pergunta suscita uma série de questionamentos acerca do verdadeiro valor da escrita e, mais globalmente, do homem das letras, cuja função é, naquele ambiente da prisão, inútil.

Ao final da cena, como já mencionado, surge uma espécie de narrador onisciente, que, por meio da supressão histórica, indica o que acontecerá a CHF. A inusitada presença desse elemento épico, narrativo por excelência, sugere a mistura de gêneros na peça, sendo esta uma característica marcante do teatro épico brechtiano. Tendo reformulado o teatro épico em sentido de estrutura dramática, com características da narrativa, Bertold Brecht, em duas fases distintas, propõe primeiramente um teatro didático, pedagógico, no qual o espectador fosse levado a pensar em uma resolução por si só, diante dos fatos apresentados no palco. Trata-se de um teatro "aberto", sem, necessariamente, um final. Já o teatro épico se desenvolveu posteriormente, com o intuito de levar o público a refletir a respeito do que produzia a emoção representada; porém, sem perder seu objetivo didático, no sentido de "ensinar" algo ao espectador.

Ao representar, aos moldes épicos, algo que remete ou tem similaridades com o presente, o teatro passa a oferecer uma experiência de reconhecimento entre o que é apresentado e o que ocorre fora dos palcos, criando no espectador a consciência de que ele é um agente capaz de mudar o presente com base no aprendizado (aspecto didático) do passado, que lhe foi oferecido por meio da peça teatral. 
Em oposição ao teatro grego clássico, em que a catarse era o objetivo final da representação, no teatro épico, espera-se que o espectador, modificado pela apreensão da experiência do passado vivida no palco, possa modificar o presente, a fim de evitar a repetição do erro cometido no pretérito. Em outras palavras, o teatro épico tem a função de ensinar a respeito do passado, de modo que o espectador reconheça em sua realidade presente os reflexos do que foi apresentado e, a partir disso, possa mudar a situação vigente.

Considerando a proposta épica da peça A viagem - Camões - Poeta prático, infere-se que o que é apresentado da vida da personagem principal, CHF, tem o objetivo de demonstrar o caráter prático das experiências adquiridas pelo poeta. Desse modo, ele não seria o arauto que imagina o que teriam sido as expedições ultramarinas, a prisão do Tronco, a vida nas Índias, ou mesmo a Inquisição, mas teria, de fato, experimentado tudo sobre o que escreveu. Por meio da metaficção historiográfica, Helder Costa confere verossimilhança à $\mathrm{CHF}$, de modo a preenchê-la com aspectos ficcionais que atendam à proposta de mostrar um Portugal não tão glorioso em seus tempos supostamente áureos. A construção de nova identidade lusitana em tempos modernos tem por chave de leitura a desmistificação do passado glorioso português por meio das bolandas de CHF, cuja obra é considerada a cristalização daquele passado heroico.

\subsection{Cena V - Ato I - Portugal e a expansão}

Em oposição ao ambiente lúgubre da cena anterior, na prisão do Tronco, essa se passa na Corte Joanina, em que está ocorrendo um sarau. Pedro de Andrade Caminha, rival de CHF, declama versos. Embora já tenha feito sua primeira aparição na terceira cena desse ato, quando D. Fernando de Noronha queixa-se ao rei acerca da conduta desrespeitosa de seu criado, o poeta, contemporâneo de $\mathrm{CH}$, demonstra-se servil à fidalguia, bem como ansioso por rebaixar seu adversário, como se pode depreender no excerto a seguir:

PEDRO ANDRADE DE CAMINHA - Toda verdade, minha estimada Rainha. Esse Camões, poeta menor, notório libertino e hereje, ofende a honra da nossa melhor fidalguia, espalhando a fama de ser amante da esposa de D. Fernando de Noronha. (COSTA, 1982, p. 41).

A alusão a CHF como libertino, herege e poeta menor resulta, conforme é sugerido na peça, de sua relação com a Nobreza, sendo, por isso, plausível aceitar que o nome do autor d'Os Lusíadas não figurasse dentre os grandes da época na Corte Joanina. Dessa feita, ser bom poeta não 
implicava necessariamente na qualidade real da escrita, mas, sim, nas relações que o artista mantinha com a Nobreza. Tal alegação encontra escopo no fato de que Caminha está a declamar versos a D. Francisca, nobre que teria contratado CHF para lhe glosar alguns versos, mas que, em face dos acontecimentos, aceita de bom grado o belíssimo poema, provavelmente encomendado.

Em fragmento subsequente à declamação de Pedro Andrade de Caminha, um fidalgo menciona o fato de que: "Por alguma razão, é nosso melhor poeta..." (COSTA, 1982, p. 47) sugerindo, pelo uso do pronome possessivo e pelo contexto, que Caminha é o melhor para a fidalguia, pois cumpre seu papel social de agradar aos integrantes da Corte, por meio de uma obra que não oferece "contestação crítica" ao contexto em que está inserida, em oposição a CHF, personagem que reproduz a cosmovisão de Helder Costa, e que, no texto teatral, mostra-se à frente de seu tempo, embora, por este aspecto, difira-se de $\mathrm{CH}$, posto que esse não escreveu com tamanha criticidade acerca de seu próprio contexto. Prova disso encontra-se em Os Lusíadas, no qual apenas na personagem do Velho do Restelo e no Epílogo são apresentadas visões negativas a respeito das navegações ultramarinas.

Com a finalidade de distraírem-se um pouco da monotonia do sarau, alguns nobres sugerem brincar às prendas ${ }^{56}$. Embora o padre, como representante do Clero e ciente de que jogos de qualquer espécie não são permitidos, oponha-se à sugestão, acaba por integrar o grupo. Como sugere um fidalgo: “O padre também entra no jogo, está bem?” (COSTA, 1982, p. 47). O termo jogo, aqui, deve ser compreendido em dois sentidos: um literal, com relação à brincadeira proibida pela Igreja, por usar cartas, outro figurado, quando remete ao manejo habilidoso de determinada situação, no intuito de obter vantagens.

A Nobreza e o representante do Clero divertem-se com a brincadeira, estabelecendo um ambiente licencioso ou, até mesmo, libertino. Todavia, a atmosfera alegre é substituída pela sobriedade e pela desfaçatez dos exercícios espirituais de Santo Inácio de Loyola ${ }^{57}$, que são praticados ainda hoje na Igreja durante a Quaresma, com a intenção de purificar as almas e preparálas para a festa da Páscoa.

O recurso intertextual da paródia é novamente empregado nessa cena, quando os nobres praticam exercícios espirituais para disfarçar a brincadeira de prendas. A forma das orações é mantida, porém, é subvertido seu conteúdo, considerando que se configuram apenas como palavras vazias naquele contexto. Uma vez mais, a ideia de "jogo" ganha novos contornos, pois não se trata

\footnotetext{
${ }^{56}$ Divertimento de sala em que se devem dizer ou fazer certas coisas, pagando uma prenda à pessoa que não as diz ou não as faz bem, e ficando por esse fato sujeita a cumprir a penitência que lhe for imposta. Definição disponível em: http://www.priberam.pt/dlpo/jogo, Acesso em: 25 jan. 2015.

${ }^{57}$ Cortesão durante a juventude, converteu-se e abdicou de todos os bens materiais, passando a viver de mendicância. Buscou redimir-se da vida desregrada através de exercícios espirituais que objetivavam alcançar a pureza da alma por meio da oração e do jejum. Destacou-se também por ser um dos fundadores da Companhia de Jesus.
} 
apenas de manejar a situação de maneira favorável, mas também de fazer crer que aquele disfarce é factual. Em outras palavras, o jogo consiste em simular noções de verdade ou mentira, sem alterálas na essência.

O sentido de jogo como simulacro é bastante explorado na sequência da cena, quando o rei D. João III se reúne com os ministros e o bispo para discutir a respeito das providências relativas aos pagamentos e acertos que a Coroa deve fazer. Embora a religião pregue a conduta desprovida de objetivos pessoais, os governantes portugueses estão imbuídos pelo desejo de obter vantagens pessoais, legando o discurso religioso ao plano da falácia. Estabelece-se, nesse ponto, o entrecruzamento dos diálogos entre as autoridades clericais e monárquicas e os exercícios espirituais feitos pelos nobres, construindo-se um terceiro discurso irônico, crítico e, acima de tudo, paródico em relação aos dois outros discursos que o compõem. A paródia é considerada por Linda Hutcheon (1991), como o instrumento, por excelência, do pós-moderno, visto que estabelece relação de contradição com o modelo. Ainda segundo a teórica, a definição de pós-modernismo está relacionada à efetiva contestação e rejeição de metanarrativas.

Novamente vem à tona o atrito, previamente comentado na visão de Patrice Pavis (2008), conforme se pode observar no excerto retirado da cena em análise:

(Instalam-se noutra zona do palco. Ao mesmo tempo, a acção dos exercícios continua).

BISPO - Pedia a Vossa Majestade que fosse pagas as despesas da Capela Real. São muitos os frades, as religiosas, os capelães (...)

PADRE - Exercício para me corrigir, diminuindo-me com exemplos...

BISPO - Temos de continuar a dar esmolas ao povo.

D. JOÃO III - Sim. Cuidado, bispo...

D. FRANCISCA - Que coisa são os homens em comparação com todos os anjos e santos do paraíso...

MINISTRO 3 - As despesas da Corte... alimentação, vestuário, móveis, novos criados, mais fidalgos... (...)

FIDALGO 1 - Considerar toda minha corrupção e fealdade corpórea...

FIDALGO 2 - Ver-me como uma chaga de onde saíram pecados, maldades e torpíssima pessoa.

BISPO - Novas obras de caridade. (...)

PADRE - Não querer pensar em coisas de prazer, nem de alegria. Não rir, nem dizer coisa que provoque o riso.

BISPO - Temos de pagar aos oficiais da inquisição e aos crentes que denunciam os herejes.

PEDRO ANDRADE CAMINHA - Louvar todos os preceitos da Igreja, estando sempre dispostos para buscar razões em sua defesa, e, de nenhuma maneira, para os atacar. (...)

(COSTA, 1982, p. 49 -51). 
O diálogo paródico é construído por meio da fusão dialógica entre as falas menores da cena, construindo, assim, um efeito de sentido peculiar e altamente subversivo com relação a seus paradigmas. Trata-se de um atrito simbólico entre os discursos, evidenciando a interdependência entre a Corte e o Clero, de modo que o rei assegure a posição privilegiada da Igreja, enquanto que essa, em contrapartida, divinize o poder monárquico, fortalecendo-o. $\mathrm{O}$ entrecruzamento dos diálogos, ao fim e ao cabo, não se limita a tratar apenas da fusão entre ambas as instituições, pilares daquela sociedade, mas fundamentalmente em demonstrar como os vícios da corrupção, da torpeza e do descaso com os verdadeiros interesses da Nação aceleraram a derrocada do Império lusitano. Helder Costa apresenta, novamente pelo viés do teatro épico, as fragilidades daquele Portugal aparentemente áureo e próspero, que, anos mais tarde, viria a submeter-se ao domínio espanhol.

A debilidade portuguesa é, por vezes, parte da preocupação dos ministros, quando apresentam ao rei a falência econômica e militar do sistema monárquico, além da fraqueza moral, que é evidenciada pela paródia dos exercícios espirituais ao fundo da cena.

MINISTRO 5 - (...) Há castelos em ruínas, canhões que não funcionam. (...) MINISTRO 3 - As caravelas estão velhas, os embarcadiços querem mais dinheiro. (...)

MINISTRO 2 - Majestade, não tem vindo barcos da Índia. Houve desastres, derrotas militares (COSTA, 1982, p. 50-1).

A expressão castelos em ruínas, além de ser uma metáfora para a cena como um todo, constituindo-se em imagem forte para a própria Nação Portuguesa em evidente declínio, é também metonímica, posto que castelo remete, no contexto, à Monarquia caindo por terra. Tal afirmação encontra escopo na personagem de D. João III, caracterizada como rei carola, displicente, omisso com relação às suas obrigações reais e profundamente acomodado com a situação do país, como é possível observar no excerto abaixo:

ESCRIVÃO - Majestade, perdoai-me. Quase não há dinheiro.

D. JOÃO III - Não há dinheiro? Não há dinheiro? Que história é essa?

MINISTRO 1 - Há muitas despesas, Majestade! A Corte, tudo o que temos de comprar a outros países, o trigo, o sebo, os vinhos...

D. JOÃO III - Já sei, já sei. Não produzimos nada. Estou farto de ouvir isso. Não tem sido sempre assim? (...) Que se faça um empréstimo. À Flandres... (...) Enquanto o pau vai e vem, folgam as costas. As coisas hão-de melhorar. Bispo, o que faz a Inquisição? Já não há judeus a perseguir? Para que é que se está a pagar uma enormidade aos padres do Santo Ofício, para que é que eu paguei uma fortuna ao Papa, se esses judeus andam por aí, e o dinheiro não entra nos cofres da Coroa? (COSTA, 1982, p. 51-2). 
A personagem do rei D. João III apresenta postura resoluta em manter os altos gastos da Coroa, especialmente no que tange à importação de produtos para satisfazer as demandas da Corte. Momento de destaque no excerto está na admissão de que Portugal não produz nada, apenas consome o que outros produzem, sugerindo que esse comportamento tenha sido adotado desde tempos remotos, indicando, uma vez mais, um aspecto da decadência enfrentada pelos lusitanos. Em adição ao discurso conformista, o monarca pede uma solução rápida, embora pouco efetiva, de que se faça um empréstimo para mascarar o problema da falta de dinheiro. Ademais, a personagem demanda explicações a respeito da não efetividade da perseguição aos judeus, insinuando que a Inquisição tinha interesses não só relativos à religião, mas também à apropriação dos bens daqueles que eram perseguidos.

Ao expor, por meio de diálogos entre Clero e Monarquia, os vícios de toda ordem escondidos no alicerce em que Portugal se sustentava, Helder Costa exprime uma visão bastante negativa a respeito da ideia de que as expedições ultramarinas foram em todos os aspectos positivas. Ao revés, ele se propõe a ressaltar as mazelas, as caraterísticas pouco nobres, interesseiras e, até mesmo, sanguinolentas, que ficaram por anos escondidas pelas benesses do período em que Portugal foi o centro do mundo. Acredita-se que a intenção não tenha sido, em essência, desmerecer o que foi feito nessa época histórica, porém, sem dúvida, o objetivo que se desenha mais claramente a cada cena é o de desnudar, mediado pela cosmovisão do dramaturgo, outras facetas desse período em que os horizontes de mundo foram para sempre alargados.

\subsection{Cena VI - Ato I - Enchem-se as caravelas}

Em virtude da prematura autonomia como reino independente, da posição geográfica favorável e da necessidade que o país tinha de novas fontes de renda para garantir seu crescimento, além das constantes guerras contra a Espanha, Portugal lançou-se ao mar, ou seja, em: "aventuras marítimas consideradas temerárias e infrutíferas pelos estados mais pragmáticos e prudentes da Europa (...)" (ARNOLD, 1983, p. 37). O temido enfrentamento do desconhecido oceano, por si só, já desafiava a ideologia teocêntrica dominante da época, especialmente no que se refere ao país lusitano, profundamente católico desde a origem.

Como já se comentou no capítulo anterior, Portugal não foi humanista, no sentido de desenvolver o estudo dos ideais antropocêntricos, largamente difundidos pelo Renascimento italiano. Todavia, foi primeiramente Classicista, na medida em que, por meio das navegações ultramarinas, pôs em prática o que o Humanismo teorizou. 
Embora as expedições tenham começado no reinado de D. João II, esse não viu os frutos de seus investimentos. Quem os colheria seria seu sucessor, D. Manuel I, O Venturoso, em cujo reino se deu a parte mais significativa das descobertas marítimas. Foi nesse período que a conquista de novos caminhos para as Índias se tornou uma necessidade comercial e política, pois proporcionava a Portugal a possibilidade de expandir o comércio e o domínio sobre novas terras. Porém, o pequeno reino lusitano conquistou tanto e tão longe de seus domínios, que passou a ter a árdua tarefa de proteger os novos territórios. Isso significava estar em lutas constantes e dispendiosas contra os invasores, além de arcar com gastos exorbitantes de manutenção das colônias, tais como ajuda financeira para que as pessoas pudessem estabelecer residência ali e, dessa forma, garantir o domínio português.

Porém, a política de gastos excessivos com as colônias, aliada às regalias da vida luxuosa da Corte lusitana, vieram a acentuar o grave problema financeiro por que passava o país, visto que dependia, quase que inteiramente, do que era produzido e arrecadado nas colônias. A dependência estimulou sobremaneira novos investimentos em expedições ultramarinas, na esperança de que fossem descobertas riquezas que pudessem pôr fim à angústia lusitana de uma economia fraca e decadente. $\mathrm{O}$ discurso da ruína aparece significativamente, por meio da personagem do rei. Em suas falas, são expressas as ideias de que Portugal não produz nada, é dependente de empréstimos para manter-se e, mesmo estando ciente dessa realidade, não encontra, exceto por meio das caravelas, uma solução efetiva para a crise pela qual passa. Note-se que a personagem de D. João III é apresentada por Helder Costa de maneira impiedosa, com vista a expor acomodação e ineficiência por parte daqueles que têm o poder de mudar o rumo do país e nada fazem a respeito.

A cena em análise é consequência da anterior, quando o rei decide enviar novas expedições em busca de terras e, para tal, deseja que as caravelas estejam repletas de gente pronta a partir. Todavia, aventurar-se pelo desconhecido perigo, correndo o risco de jamais retornar à Pátria, não se configurava como a opção mais sensata. Assim, rareavam voluntários dispostos a embarcar. A cena enfoca os diferentes discursos empregados para cada segmento social, a fim de convencer as pessoas a tomar parte nas missões em alto-mar.

Com o objetivo comum de encher as caravelas, cada uma das personagens ligadas à monarquia discursa para convencer os ouvintes de que as expedições são uma oportunidade de honrar sua linhagem, no caso dos nobres, uma oportunidade de enriquecimento fácil, no caso dos comerciantes, de salvação, para os camponeses, e de benevolência real, para os presos.

O primeiro discurso, do ministro para seus filhos, aponta as expedições ultramarinas como uma necessidade de garantir junto ao rei seu prestígio social na Corte, de acordo com o excerto abaixo: 
MINISTRO 1 (À Mesa, enquanto come, fala com sua mulher e seus dois filhos) (...) mas penso que temos de tomar, urgentemente, uma decisão. A nossa família tem pergaminhos a defender, não podemos permitir que linhagens inferiores à nossa se acerquem de El-Rei e se apoderem de seus favores. O nome da nossa casa foi valorosamente escrito com sangue heróico em campos de batalha contra os herejes, e em corajosas viagens a esses longínquos Mundos do Bárbaro gentio. Quero que meus dois filhos se alistem nas caravelas que estão prontas a largar para a Índia. Irão estar perto do comandante da expedição. Assim, seguirão a carreira militar dos seus avós, e prepararão o futuro que mais convém ao nosso sangue. (COSTA, 1982, p. 53)

A ideia central do discurso está na defesa da honra tradicional dessa família, visto em não permitir que "linhagens inferiores" usurpassem seu lugar. $\mathrm{Na}$ fala da personagem, é possível perceber a forte presença remanescente do ideal medieval de que o nobre tinha a função de proteger o que lhe pertencia, visto que sua descendência "superior" assim o havia predestinado, por meio de seu sangue nobre. No excerto, pode-se observar que o ministro exalta conquistas e façanhas heroicas de seus antepassados para exemplificar o tipo de atitude que é esperada dessa linhagem, , ao fim do discurso, os filhos beijam-lhe a mão e consentem em embarcar.

$\mathrm{Na}$ sequência, outro ministro conversa com comerciantes, expondo-lhes as inúmeras vantagens das expedições ultramarinas no que concerne aos vultosos ganhos que esses obteriam com a venda de especiarias trazidas das Índias, tendo em vista que os nobres que embarcariam apenas estariam interessados em glórias e em manter suas posições na Casa Real:

MINISTRO 2 - (numa loja, falando com comerciantes) - Vão sair mais caravelas. El-Rei D. João III quer expressar as expedições. Isso vai trazer muito dinheiro a quem souber trabalhar. E, como sabemos, os nobres só querem glórias e poucos incómodos e perigos. Metem-se em caravelas, para assegurarem o futuro, na Casa Real. Estão no seu direito, e são sonhos que os comerciantes, não podem ter. Mas se quiserdes, podeis enriquecer em muito pouco tempo. Basta saber esconder a canela, a pimenta, e até o ouro, se tiverem sorte, e negociá-lo, em paz, e sossego, aqui em Lisboa. Eu arranjo-vos lugar nas caravelas, mas terei de me dar... (COSTA, 1982, p. 53-4).

O discurso do enriquecimento fácil é usado para compensar a limitação hierárquica em que repousa a organização social lusitana, pois pertencer à Nobreza requeria linhagem nobre, e isso o comerciante não possuía. No entanto, as expedições ultramarinas eram a promessa de que, por meio do acúmulo de posses, o burguês poderia galgar seu lugar naquela sociedade. O ministro 2 corrobora, por meio de sua afirmação de que os nobres embarcam apenas para assegurar sua posição privilegiada na Corte, o que foi dito pelo ministro 1, sugerindo uma espécie de discurso 
coletivo de que as aventuras marítimas se constituíam como tábua de salvação aos portugueses, seja como manutenção da ordem hierárquica de poder para a Nobreza, seja como aspiração à representatividade nessa sociedade, no caso dos comerciantes.

Complementando os aspectos políticos e econômicos que justificam o embarque nas caravelas, surge o discurso religioso, que busca convencer os fiéis a embarcar como forma de atender à vontade divina de expulsar os hereges, a missão evangelizadora da Igreja, sendo, para tal, recompensados com terras férteis para o cultivo:

BISPO - Que duro é este trabalho! Que labor tão insano! E que injustiça trabalhar tanto, para serdes tão mal compensados! Escutais, meus irmãos: porque não procurais outras terras, essas terras distantes onde dominam os infiéis que conspurcam a face da terra, assim adiando a chegada do Senhor? As caravelas que vão fazer ao mar, esperam por vós. São caravelas abençoadas que vos transportarão para terras férteis, onde podereis enriquecer facilmente, expulsando os herejes. Para quê tanto sofrimento, aqui, penando neste solo inculto, se é a palavra de Deus que vos indica os campos verdejantes e frescos onde podereis viver em plena felicidade? Para quê hesitar, se vossa ida nas caravelas faz parte da missão evangélica da igreja? Vinde, meus irmãos! (COSTA, 1982, p. 54).

Distintamente dos discursos anteriores, esse é proferido por uma autoridade religiosa, cujas palavras demonstram "simpatia" pelos camponeses (embora a Igreja Católica fosse fiel defensora da sociedade teocêntrica estamental), com o intuito de convencê-los de que as "injustiças" que sofriam poderiam cessar definitivamente. A postura submissa dos campesinos, que ouvem o bispo ao fim de sua promessa de felicidade divina, demonstra a influência religiosa característica do período.

A promessa de enriquecimento fácil também se faz presente no discurso. No entanto, não há menção de que os camponeses retornariam a Portugal após expulsarem os hereges. Subentende-se que permaneceriam nas terras conquistadas, cultivando e, consequentemente, garantindo a possessão portuguesa do espaço.

Encerram-se, assim, os discursos de convencimento das diferentes camadas sociais que, por distintos motivos, embarcam nas caravelas. Porém, inicia-se o último discurso, proferido aos presos da cadeia do Tronco, dentre os quais está CHF. Nele, objetiva-se comunicar aos detentos acerca da "bondade infinita do rei", que se manifestará por meio do perdão dos crimes cometidos, concedido àqueles que embarcarem rumo às Índias:

MINISTRO 4 - Tenho a dizer-vos que, por benevolência extrema de El-Rei D. João III, foi decidido dar-vos uma oportunidade para serem perdoados pelos vossos crimes.

Nesta cadeia do Tronco, neste lugar repugnante e vergonhoso, só entram homens de baixíssimos instintos, gente sem coração e sem merecimento. 
Mas a bondade de El-Rei é infinita, assim vos as saibais compreender e agradecer. Vão sair caravelas para a Índia. Vamos combater os infiéis e precisamos de soldados. Esse será o vosso lugar. Se o vosso comportamento for valente e corajoso, honrando Portugal e Jesus Cristo, sereis perdoados.

Os melhores de vós poderão seguir a carreira das armas, outros poderão entrar na Guarda Real, e ainda irão beneficiar de rendas e benefícios que a Pátria sempre soube oferecer aos seus melhores filhos. Viva El-Rei D. João III! (COSTA, 1982, p. 55-6).

O tom do ministro indica que os presos não têm escolha a não ser embarcar, e que, acima de tudo, deveriam estar gratos pela segunda chance que lhes fora proporcionada graças à "bondade infinita do rei". Semelhante aos faraós do antigo Egito, a personagem do rei D. João III tem o poder de decidir quem vive e quem morre, e, ao agraciá-los com uma oportunidade, esses devem abraçá-la e fazer seu melhor. Embora o discurso ressalte a baixeza dos homens que se encontram na cadeia, o ministro explicita que são necessários soldados que combatam os hereges e, por não terem o que perder, os prisioneiros são a indicação mais óbvia à perigosa missão. Ademais, esses terão a oportunidade de se mostrarem úteis à Pátria e, se assim o forem, serão recompensados pelos serviços prestados, tanto com o perdão divino quanto com os privilégios que Portugal lhes poderia conferir ao retornarem.

Ao retratar as intenções reais que impeliam as expedições em alto mar, tais como a manutenção da vida dispendiosa da Corte e a acomodação com a situação decadente que o país enfrentava, a peça de Helder Costa constrói um Portugal profundamente doente, já a sentir os impactos da ruína econômica, social e moral sobre esse grandioso império, agora em declínio. 


\section{A VIAGEM E SEUS DESDOBRAMENTOS}

Acusa as injustiças e prepotências dos governantes, denuncia a Igreja mistificadora, ataca a barbárie da Inquisição, combate a ignorância e o medo, mas ama tua Pátria. Nós mostramos novos Mundos ao Mundo, e muitos de nós, os que acreditam na mudança das coisas, querem o amor e a paz, entre todas as raças.

É uma luta que dura há séculos.

Precisamos de poetas que saibam cantar... COSTA, 1982.

\subsection{Cena VII - Ato I - A Viagem}

Essa cena, como o próprio título indica, trata da viagem de CHF a Goa ${ }^{58}$, após sua estadia de alguns meses na prisão do Tronco. Em concordância com o que foi discutido no início do capítulo anterior, acerca das possíveis interpretações simbólicas da palavra viagem, infere-se que, em sentido geral, essa remeteria ao trajeto percorrido para atingir um objetivo maior. No caso do título da peça, viagem remete, dentre outras possíveis leituras, à busca de uma nova visão acerca das expedições ultramarinas portuguesas. No que tange a CHF, viagem está ligada à mudança, especialmente pelo fato de o poeta ser impelido pelas circunstâncias a deixar seu país e encontrar novas aspirações de vida.

Além das sugestões simbólicas atreladas ao termo viagem, deve-se explorar seu significado mais direto: o ato de locomover-se de um ponto a outro. Especificamente no caso das navegações portuguesas dos séculos XV e XVI, que eram envoltas por "crença popular de que os navios que se aventurassem nos mares desconhecidos se arriscavam a cair mundo abaixo ou a serem engolidos pelos mares ardentes da 'zona tórrida'. Tais receios eram um poderoso trovão à exploração e investigação prática" (ARNOLD, 1983, p. 14-5). Em vista da débil situação em que se encontrava Portugal, já indicada na quinta cena do primeiro ato, as expedições passaram a ser consideradas a tábua de salvação contra a decadência. Segundo José Hermano Saraiva:

A expansão era pois a solução das contradições fundamentais da vida colectiva nacional. As crises medievais, que haviam oposto os reis ao clero, a nobreza ao povo, os grandes aos pequenos, tinham todas na sua base a mesma explicação: desproporção entre recursos que aumentavam devagar e necessidades que cresciam depressa, entre a produção de pouco por uns e o consumo de muitos por outros. (...) A expansão passa a constituir desde então uma espécie de grande projecto nacional, ao qual todos aderem porque todos esperam vir a ganhar com ele. (SARAIVA, 1996, p. 137).

\footnotetext{
${ }^{58}$ Camões teria embarcado para Goa após a expedição da carta régia de perdão, em 1553.
} 
As expedições ultramarinas foram compreendidas como a perfeita união de interesses políticos e religiosos. Elas poderiam beneficiar tanto o crescimento da economia quanto o da religiosidade. O discurso do Estado se concentrou em promessas de riquezas fáceis e, no caso dos nobres, na esperança de alcançar a glória. À Igreja coube recriar o ideal cavalheiresco, cuja força vinha da divindade de sua missão: espalhar a religião e combater os infiéis, muito semelhante ao que se deu durante o período das Cruzadas. Nas palavras de A. H. Oliveira Marques:

Razões económicas e sociais, todavia, são geralmente insuficientes para uma compreensão global de qualquer feito da Idade Média. Dão-nos a base, a plataforma raccional da acção, mas omitem esse invólucro colorido que todo homem exige para se desculpar a si próprio e para convencer os outros de uma empresa nobre e idealista. No caso da expansão do século XV, um tal invólucro era feito de contextura religiosa dupla: a luta contra o infiel e a salvação das almas. (...) Expansionismo e imperialismo políticos eram meios legítimos de converter o infiel, da mesma forma que a redução ao cativeiro. Assim, não admira que a Igreja aprovasse a expansão portuguesa e lhe desse a sua mais calorosa bênção. Sucessivas bulas papais, aliás engenhosamente negociadas pelos representantes portugueses em Itália, apoiaram os projectos militares de Portugal ou aplaudiram as conquistas já levadas a efeito, rotulando uns e outras de santos e de cruzada, convidando soberanos cristãos a darem-lhe ajuda, concedendo indulgências e até uma percentagem nos rendimentos da Igreja - fim desde sempre almejado. (1974, p. 248-9. v.1).

No caso das campanhas pelo mar, os discursos do Estado e da Igreja, em geral apelativos e sentimentais, unificaram-se, com o intuito de convencer a população a embarcar nas caravelas em direção à África. Entretanto, isso não significou adesão massiva à crença de que as expedições resolveriam os problemas portugueses. Ao revés, havia inúmeras vozes contrárias aos gastos excessivos e às incontáveis vidas perdidas na busca por uma alternativa, que parecia incerta, para as dificuldades que o país enfrentava.

Assim, a última cena do primeiro ato é composta por momentos distintos, em que são exibidas diferentes faces da viagem. Logo de início, estabelecem-se dois polos opostos na cena: os que encorajam o embarque dos homens nos navios, creditando-lhes o status de missão divina, e o segundo, em que personagens femininas imploram para que seus entes queridos não subam a bordo rumo ao desconhecido:

PADRE 1 - Que Nosso Senhor Cristo nos proteja!

PADRE 2 - Dai-nos forças para combatermos os herejes!

MULHER VELHA - Que vai ser de mim, sem o amparo do meu filho?

MULHER NOVA - Deixem-me o meu homem... Não me roubem o meu homem...

PADRE 1 - Orai, pecadores, pela salvação da nossa alma... 
(COSTA, 1982, p. 57).

Os sacerdotes rezam pelo sucesso da expedição, reafirmando o compromisso de combate aos hereges, incitando os ideais cavalheirescos que, séculos antes, impeliram a Nobreza às Cruzadas. Os clérigos pedem força de combate e proteção às almas, sugerindo que, no caso de iminente morte na viagem, as almas da tripulação estariam a salvo. $\mathrm{O}$ empreendimento das expedições não contava com nenhuma garantia de sucesso (embora fosse visto pelo Estado e pela Igreja como fadado ao êxito) e, por isso, suscitava incertezas a respeito do destino dos que se arriscavam nessa missão.

Considerando que a sociedade portuguesa era fundamentalmente patriarcal $^{59}$, a viagem representava a partida dos homens, protetores, maridos, filhos; isto é, daqueles que eram responsáveis por zelar pelas mulheres da época. Tal clamor por piedade diante da incerteza do destino é representado nas falas das personagens mulheres, tanto velha quanto nova, que veem na partida o abandono do lar e das obrigações, que seriam deixadas para trás com o embarque. $\mathrm{Na}$ tentativa desesperada de impedir que um ente querido suba a bordo da caravela, uma mulher acercase de um homem, mas, sem obter sucesso em seu intento, é repelida com violência por um soldado. Ao presenciar a cena, um padre profere a célebre frase de Jesus ao ser crucificado: "Perdoai, Senhor, que não sabem o que fazem" (p. 58) ${ }^{60}$.

No contexto em que é proferida há a estilização, pois percebe-se a duplicidade de sentidos da sentença, que pode ser lida como a reprovação do padre contra a atitude brutal do soldado, repudiando a violência praticada contra a mulher; ou ainda com o clérigo dirigindo-se à senhora, na medida em que sua atitude pudesse impedir que o homem seguisse seu glorioso destino, o que também significaria fazer a vontade divina. Ao considerar esse último sentido, a estilização fica ainda mais significativa, pois estabeleceria o paralelo entre o sacrifício de Cristo e o que está para acontecer aos que embarcam nas caravelas.

Corroborando o ideal de que a morte em luta é gloriosa, um nobre irrita-se com as lamúrias da multidão chorosa, demonstrando forte cultura de guerra, aos moldes dos heróis cavalheirescos medievais, quando se acreditava que uma vida curta, abreviada pelo sacrifício em batalha, era mais valiosa do que uma longa existência sem honra. Novamente o ideal da cultura bélica como fonte de honra é evidenciado na peça, primeiramente nos discursos de convencimento dos nobres e, especificamente nessa cena, como mola propulsora da Nobreza, que embarcava nas expedições.

O culto ao combate perdurou por muitos séculos, desde as primeiras civilizações, simbolizado na mitologia por Ares (nome grego) ou Marte (nome latino), que designava o Deus da

\footnotetext{
${ }^{59}$ Mulheres também embarcavam nas caravelas rumo aos novos mundos.

${ }^{60}$ A frase original era "Pai, perdoa-lhes, porque não sabem o que fazem" In Bíblia. Lucas, cap. 23, v. 34. Disponível em https://www.bibliaonline.com.br/acf/lc/23 Acesso em: 25 jan. 2015.
} 
Guerra, até sua proibição, em virtude do estabelecimento definitivo das religiões monoteístas. No entanto, notam-se alguns resíduos dessa cultura de guerra nos nobres durante a Idade Média. Desde pequenos, eram educados militarmente, treinados para defender o território e combater qualquer inimigo. Sabendo desse potencial guerreiro, diversas ações, como as Cruzadas e a expansão ultramarina, foram incentivadas pela Igreja Católica a partir dos ideais de combate aos infiéis e da propagação da fé, o que resultou inevitavelmente em guerras santas e, supostamente, em honra aos "Cavaleiros de Cristo".

A visão explicitada por Helder Costa na peça sugere que as viagens portuguesas de descobrimento foram motivadas por necessidades políticas, econômicas e religiosas das instituições de poder da época e, embora isso não lhes diminua o valor, ofuscam o espírito grandioso que sempre lhes esteve associado. Deste modo, o aspecto negativo do que é retratado ganha projeção, pois demonstra o gigantesco empreendimento de lançar-se ao mar quase como um capricho de um rei acomodado e sem perspectiva de investir e desenvolver o país e de uma instituição religiosa que, aos poucos, via a diminuição de sua influência e, por isso, precisava de novos seguidores.

Com a intenção de dar forma a esses discursos contrários às expedições ultramarinas, surge na cena a figura do Velho do Restelo. A tradição literária tem na figura do Velho o símbolo da experiência, cujos conselhos se embasam em seu amplo conhecimento do passado. Dos adivinhos que interpretavam as profecias dos oráculos, dos experientes conselheiros dos reis aos magos que povoavam o imaginário medieval, tem-se em comum o aspecto da sabedoria e/ou da previsão do futuro, com base na experiência passada. O Velho personifica o discurso da cautela diante do futuro, ponderando a respeito dos diversos aspectos da questão e, por isso, mostrando-se predominantemente resistente ao novo. Assim, o olhar do Velho se concentra em buscar fatos concretos, advindos da experiência conhecida, para formular o julgamento do desconhecido.

A personagem do Velho, na peça de Helder Costa, trava um diálogo intertextual com vistas à estilização da personagem de $\mathrm{CH}$ em Os Lusíadas, cujo papel na epopeia é o de se contrapor, ainda que brevemente, à euforia desmedida em que estavam envoltas as expedições ultramarinas portuguesas, apontando, assim, os objetivos pouco nobres e as incalculáveis somas de dinheiro que eram investidas nessas viagens, sem que, de fato, houvesse benesses à população que permanecia em Portugal. Observe os excertos de Os Lusíadas e de A Viagem-Camões - Poeta prático:

94

Mas um velho de aspeito venerando,

Que ficava nas praias, entre a gente,

Postos em nós os olhos, meneando

Três vezes a cabeça, descontente,

A voz pesada um pouco alevantando, 
Que nós no mar ouvimos claramente, C'um saber só de experiências feito,

Tais palavras tirou do experto peito:

95

_"Ó glória de mandar! Ó vã cobiça

Desta vaidade a quem chamamos Fama!

Ó fraudulento gosto, que se atiça

C'ua aura popular que honra se chama!

Que castigo tamanho e que justiça

Fazes no peito vão que muito te ama!

Que mortes, que perigos, que tormentas,

Que crueldades neles experimentas!

\section{6}

Dura inquietação d'alma e da vida,

Fonte de desamparos e adultérios,

Sagaz consumidora conhecida

De fazendas, de reinos e de impérios!

Chamam-te ilustre, chamam-te subida,

Sendo digna de infames vitupérios;

Chamam-te Fama e Glória soberana,

Nomes com quem se o povo néscio engana!

97

A que novos desastres determinas

De levar estes reinos e esta gente?

Que perigos, que mortes lhe destinas

Debaixo dalgum nome preminente?

Que promessas de reinos e de minas

De ouro, que lhe farás tão facilmente?

Que famas lhe prometerás? que histórias?

Que triunfos? que palmas? que vitórias? (...)

99

Já que nesta gostosa vaidade

Tanto enlevas a leve fantasia,

Já que à bruta crueza e feridade

Puseste nome "esforço e valentia",

Já que prezas em tanta quantidade

O desprezo da vida, que devia

De ser sempre estimada, pois que já

Temeu tanto perdê-la Quem a dá (...)

104

(...) Nenhum cometimento alto e nefando,

Por fogo, ferro, água, calma e frio,

Deixa intentado a humana geração.

Mísera sorte! Estranha condição!

(CAMÕES, 1993, p. 170-3).

VELHO - Procurais a vaidade da Fama! Procurais o mando e o Poder! A cobiça rói-vos as entranhas, e procurais riquezas por esse Mundo (...) Assim se deixam 
velhos ao desamparo, assim se atiram mulheres para o vício e o adultério, assim, em nome de riquezas fáceis, se adormece e engana este povo...

Para quê, tantos sonhos de grandeza, se na nossa terra só se vê miséria, a doença, e a injustiça?

Para quê tantos riscos e tantos sofrimentos, se o pobre é cada vez mais pobre, e outra coisa não faz que arrastar a sua desgraçada existência?

Para quê tanto orgulho em contar façanhas e vitórias, se tudo isso é fruto do soldado, enquanto o rico se banqueteava no seu palácio? Para quê tanta mentira? (COSTA, 1982, p. 58).

$\mathrm{O}$ texto de $\mathrm{CH}$ conta com a figura do Velho, que acusa a glória, a cobiça e a vaidade da fama pelas tragédias ocorridas na Pátria. Segundo ele, a ilusão causada por esses sentimentos leva os homens a abandonarem suas casas, a lançarem-se ao perigo e à crueldade, a crer nas promessas de riquezas fáceis e a morrer por isso. Os sentimentos despertados pela cobiça e pela vaidade criam uma espécie de "venda", que impede a visão dos aspectos negativos dessas viagens ultramarinas, tais como o abandono da Pátria e o consequente esfacelamento da estrutura familiar, os perigos do desconhecido, as mortes desnecessárias e, acima de tudo, o enfraquecimento da nação, que, tendo por esperança reconquistar seu lugar de prestígio, acaba por afundar-se ainda mais, a ponto de perder-se em seus próprios enganos.

Já na peça teatral de Helder Costa, o texto paradigmático adquire um aspecto mais diretivo na crítica às navegações. O Velho, diferente do que ocorre em Os Lusíadas, não é escutado pelos tripulantes do barco, porém sua fala se mistura ao mar de lamentações dos que ficam. Infere-se que a sabedoria é desconsiderada, abrindo espaço aos atos impensados e pouco refletidos, já sinalizados como característicos da Monarquia Portuguesa, no diálogo entre D. João III e seus ministros, na cena cinco desse primeiro ato. A figura do Velho acusa não somente os sentimentos de vaidade, cobiça e busca por fama, mas, predominantemente, os sonhos de grandeza, que povoavam os discursos destinados à Nobreza, a desigualdade social, que impelia os camponeses a embarcar, e o desejo de aceitação na sociedade, que estimulava os comerciantes a seguirem viagem, além do orgulho de um passado glorioso, ainda tratado como presente, embora sem se configurar como um futuro, embasado na ilusão de que as expedições seriam a salvação do império em decadência.

Helder Costa imprime às falas do Velho a crítica às contradições da sociedade, que são evidenciadas pelas expedições: o povo fica cada vez mais pobre para financiar a busca por riquezas que não lhe caberão; procura-se a grandeza de sonhos, enquanto na terra só há privações; o soldado luta pelo que acredita, o rico mantém-se na opulência.

Trata-se de manifestação contrária à postura conquistadora da cobiça, que, segundo a peça, desencadeou vícios, misérias e desilusões na Pátria Portuguesa. A campanha ultramarina é relida criticamente como uma grande mentira a serviço dos interesses da Igreja e do Estado, os grandes 
beneficiários dessa empreitada. O discurso de estímulo às expedições carrega forte apelo popular, uma vez que, por meio dele, se configurava a possibilidade de salvação da alma e de mudança de extrato social, como se pode constatar em:

Ao começar o século XV, as condições internas criavam uma oportunidade excelente, porque a expansão correspondia aos interesses de todas as classes sociais que, no conjunto, constituíam a contraditória sociedade portuguesa. Para o povo, a expansão foi sobretudo uma forma de emigração e representava o que para ele a emigração sempre representou: a possibilidade de uma vida melhor e a libertação de um sistema de opressões e libertações que, em relação aos 'pequenos', foi sempre pesado e do qual eles também sempre se procuraram libertar buscando novas terras (a emigração para o Sul, no século XII, é primeira expressão nacional do fenômeno). Para clérigos e nobres, cristianização e conquista eram formas de servir Deus e servir o rei e de merecer por isso as recompensas concomitantes: comendas, tenças, capitanias, ofícios, tudo oportunidades que no estreito quadro da metrópole se tornava cada vez mais raro conseguir. Para os mercadores era a perspectiva do bom negócio, das matérias-primas colhidas na origem e revendidas com bom lucro. Para o rei era um motivo de prestígio, uma boa forma de ocupar os nobres e sobretudo a criação de novas fontes de receita, numa época em que os rendimentos da coroa tinham descido muito. Desta convergência de interesse só ficavam fora os lavradores, empresários das explorações agrícolas, para quem a saída de braços do País representava o encarecimento da mão-de-obra. (SARAIVA, 1996, p. 136-7).

Ainda acerca das diferenças entre o episódio do Velho do Restelo n'Os Lusíadas e n'A Viagem - Camões - Poeta prático, percebe-se que, na epopeia, o episódio refere-se à memória do momento da partida, ao passo que o episódio do Velho do Restelo é contado ao rei de Melinde, quando a expedição já havia alcançado grande parte de seu intento, enquanto na peça de Helder Costa, há a linearidade da narrativa, isto é, o fluxo natural dos acontecimentos, sendo, portanto, anterior ao alcance do objetivo da expedição. A passagem do Velho do Restelo funciona na peça quase como uma suspensão da ação, ao passo que, quando esta é retomada, já há faina normal de navegação (trabalho) dentro do navio. Um dos aspectos mais relevantes, além da crítica apresentada, é a proposta de rompimento da fronteira entre a epopeia, composta pela personagem histórica de Camões, e a vida do poeta, ficcionalizada pelo dramaturgo contemporâneo, resultando na sugestão de leitura d'Os Lusíadas como "um saber só de experiências feito" de CHF.

Retornando à cena, os tripulantes das caravelas recebem tratamento agressivo, especialmente com relação à alimentação, referida como "ração", cujo consumo desregrado implicaria em privações. Além disso, há mostra de animosidade com relação aos doentes, sendo necessário fazer "prova de doença" ${ }^{61}$ para receber o tratamento adequado. Menciona-se o escorbuto, doença que se

\footnotetext{
${ }^{61}$ Os marinheiros precisavam comprovar, de maneira concreta, por sintomas aparentes, as doenças de que padeciam, pois somente assim receberiam tratamento.
} 
caracteriza pelo inchaço das gengivas, resultante da ausência de vitamina C no organismo, característica de alimentação baseada em alimentos salgados, à qual os navegantes eram submetidos.

A personagem de CHF aparece na sequência em diálogo com o homem do leme, quando são mencionadas as inovações científicas que auxiliavam na segurança das viagens ultramarinas. Após a menção aos recursos necessários à navegação, o prenúncio de uma grande tempestade é ouvido. Gritos e clamores passam a embalar a viagem, em um episódio de horror e luta pela vida. Os homens do navio buscam refúgio na religião, a fim de estarem livres dos pecados durante a morte, que parece iminente. A furiosa tempestade faz emergir as fragilidades humanas, que haviam sido encobertas pelos discursos da Igreja e do Estado. Entre gritos, alguém clama: "Perdoai os meus pecados" (COSTA, 1979, p. 60) estabelecendo, naquele contexto, uma paródia com a oração do Pai Nosso, no qual se pede pela coletividade, e não pela individualidade.

Outro excerto a ser destacado se dá quando um homem, tomado pelo sentimento de horror pela morte, confessa seus crimes: "Quero confessar-me, padre... quero confessar-me... matei meu pai e meu irmão para lhes roubar uma arca... absolvição... tenho medo... matei meu irmão... Deus tenha piedade...”. (COSTA, 1979, p. 60). Nesse momento da cena, revela-se que os homens, responsáveis por propagar a fé católica, não têm mérito moral ou preparo para fazê-lo, visto que não a respeitam, burlando-a sempre que possível, a fim de obter benefícios individuais. Evidencia-se o paradoxo de que propagar a fé católica era um dos objetivos da colonização, porém não correspondia diretamente às ações daqueles que a disseminavam.

A tempestade que trouxe à tona os temores dos navegantes é causada pelo Gigante Adamastor, metáfora da difícil travessia na região do Cabo das Tormentas, mais tarde renomeado de Cabo da Boa Esperança, localizado no ponto de encontro entre os oceanos Índico e Atlântico. Uma vez mais, estabelece-se o diálogo intertextual entre a peça de Helder Costa e a epopeia de Luís Vaz de Camões, como pode ser constatado nos excertos de Os Lusíadas e de A Viagem - CamõesPoeta prático:

41

"E disse: - "Ó gente ousada, mais que quantas

No mundo cometeram grandes cousas,

$\mathrm{Tu}$, que por guerras cruas, tais e tantas,

E por trabalhos vãos nunca repousas,

Pois os vedados términos quebrantas

E navegar meus longos mares ousas,

Que eu tanto tempo há já que guardo e tenho,

Nunca arados de estranho ou próprio lenho; 
"Pois vens ver os segredos escondidos

Da natureza e do úmido elemento,

A nenhum grande humano concedidos

De nobre ou de imortal merecimento,

Ouve os danos de mim, que apercebidos

Estão a teu sobejo atrevimento,

Por todo o largo mar e pela terra

Que inda hás de subjugar com dura guerra.

43

Sabe que quantas naus esta viagem

Que tu fazes fizerem, de atrevidas,

Inimiga terão esta paragem,

Com ventos e tormentas desmedidas;

E na primeira armada que passagem

Fizer por estas ondas insofridas,

Eu farei de improviso tal castigo,

Que seja mor o dano que o perigo.

44

Aqui espero tomar, se não me engano,

De quem me descobriu suma vingança;

E não se acabará só nisto o dano

De vossa pertinace confiança,

Antes em vossas naus vereis cada ano,

Se é verdade o que meu juízo alcança,

Naufrágios, perdições de toda sorte,

Que o menor mal de todos seja a morte.

(CAMÕES, 1993, p. 188-9).

ADAMASTOR - Ó gente ousada, mais que quantas

No mundo cometeram grandes cousas...

Sabe que quantas naus esta viagem

Que tu fazes, fizerem de atrevidas,

Inimiga terão esta paragem,

Com ventos e tormentas desmedidas! (...)

E da primeira armada que passagem

Fizer por estas ondas insofridas,

Eu farei de improviso tal castigo

Que seja mor o dano que o perigo! (...)

Aqui espero tomar, se não me engano,

De quem me descobriu suma vingança.

E não se acabará só nisto o dano

Da vossa pertinace confiança! (...)

Antes em vossas naus vereis cada ano,

Se é verdade o que meu juízo alcança,

Naufrágios, perdições de toda sorte,

Que o menor mal de todos seja a morte!

(COSTA, 1982, p. 60-1).

Em Os Lusíadas, o Gigante é um empecilho físico ao intento português de chegar às Índias, enquanto que, na peça de Helder Costa, Adamastor representa também um impedimento simbólico 
dos limites portugueses até então conhecidos. Ultrapassá-los seria golpear o âmago do pensamento teocêntrico dominante no período. A peça sugere que o limite imposto é vencido por meio do trabalho coletivo realizado no barco, ou seja, a superação da ordem vigente (seja ela opressora ou não) ocorre efetivamente por meio do esforço coletivo da sociedade. Essa interpretação pode estar, ainda que indiretamente, relacionada ao viés socialista do autor da peça, cujo engajamento político marca forte presença em sua concepção de teatro, o qual é inspirado no modelo brechtiano de teatro épico. Este, segundo Anatol Rosenfeld, se diferencia do teatro aristotélico clássico por considerar:

(...) primeiro, o desejo de não apresentar apenas relações inter-humanas individuais (...) O homem concreto só pode ser compreendido com base nos processos dentro e através dos quais existe. (...) A segunda razão liga-se ao intuito didático do teatro brechtiano, à intenção de apresentar um 'palco científico' capaz de esclarecer o público sobre a sociedade e a necessidade de transformá-la; capaz ao mesmo tempo de ativar o público, de nele suscitar a ação transformadora. $\mathrm{O}$ fim didático exige que seja eliminada a ilusão, o impacto mágico do teatro burguês. (ROSENFELD, 2006, p. 147-8).

A peça é construída nos moldes do teatro épico, sob a óptica de que, para se compreender algo, é necessário ampliar as relações humanas daquele contexto. Assim, deriva a descrição e a representação detalhada de episódios que ladeiam e embasam a visão crítica acerca das expedições ultramarinas.

Ao representar personagens fracas, acomodadas, hipócritas e falaciosas, Helder Costa almeja evidenciar que o fato de Portugal ter ocupado posição de destaque no cenário mundial durante o período das descobertas marítimas não significou que o povo português como um todo tenha usufruído dessa posição privilegiada, mas sim que os benefícios das empreitadas ao mar estiveram restritos a alguns extratos daquela sociedade, ao passo que a decadência, que ocorreu anos mais tarde, assolaria toda a população.

\subsection{Cena I - Ato II - Espalhar a Fé e o Império}

Essa cena é uma releitura, a partir do texto de Luís Vaz de Camões, do encontro entre portugueses, em sua passagem pelo reino de Calicute, e mouros calicutenhos, liderados pelo Samorim.

Antes de iniciar a análise, cabe ressaltar a importância das marcações de cena a partir do início deste ato. Elas permitem a distribuição dos espaços da cena, além, é claro, no caso da leitura, de servirem para contextualizar e demarcar detalhes da encenação, desde a composição do cenário, 
passando pelas especificidades que devem ser expostas em determinado ponto da cena pelos atores, até a caracterização das personagens.

Especificamente nesta cena, três rubricas são fundamentais para sinalizar elementos para além das falas e das ações das personagens. Exemplos da importância das marcações cênicas podem ser observados quando se afirma que a representação do barco não deve ser Naturalista, tendo em vista que a peça pressupõe que não haja identificação imediata entre a plateia e os elementos representados. Outro exemplo encontra-se na descrição de uma tentativa de comunicação frustrada entre os portugueses e um nativo, o que acresce ao contexto da cena a explicitação da ausência de uma mentalidade comum, que viabilizasse o diálogo entre eles.

A cena em análise trava o diálogo intertextual com o episódio d'Os Lusíadas em que os portugueses haviam chegado a Calicute e foram recebidos por Monçaide, um mouro que já estivera em Castela (logo, sabia se comunicar com os portugueses). Na sequência, esses são recebidos pelo Samorim, que, por interferência do deus Baco, não estabelece relações amistosas com os visitantes, tanto que Vasco da Gama parte de maneira conturbada do lugar.

A primeira marcação de cena que aparece após a menção intertextual aos Cantos VII, VIII e IX d'Os Lusíadas, indica o escambo, prática bastante comum dos colonizadores ao estabelecer contato com os nativos, como se nota no excerto a seguir, da peça de Helder Costa:

(...) vestem o preto com panos de cores vivas, um barrete vermelho, contas de vidro, e pequenas campaínhas. Alegria geral. Ele foge, o barco continua a andar. Aparecem o mesmo preto, acompanhado por outros, e por um mouro. Ao mesmo tempo que o mouro fala com Vasco da Gama, os portugueses vestem os outros da mesma maneira (1982, p. 64).

Assim que se estabelece o contato com os mouros, os lusitanos demonstram completa ignorância quanto à cultura e aos costumes nativos, em oposição aos calicutenhos, que conhecem minimamente o povo português. Este comportamento elucida o tipo de relação que os colonizadores almejavam estabelecer nas descobertas: tirar o maior proveito possível das terras "de riquezas abundantes", seja por meio da colonização exploratória, seja pelo saque. A parceria comercial de fato nunca esteve em questão, como a cena sugere, sendo apenas utilizada como pretexto para o contato com outros povos.

Tanto n'Os Lusíadas quanto em A Viagem - Camões - Poeta prático, o diálogo inicial entre o mouro, que conhecia os portugueses, e estes, tem por objetivo estabelecer a confiança necessária para que fossem recebidos pelo Samorim. O líder dos nativos do local recebe os visitantes com cordialidade, até que se reúna com seus conselheiros e decida que os navegantes são uma ameaça. 
$\mathrm{Na}$ epopeia, Baco aparece em sonho a um dos conselheiros de Samorim, para que este rejeite a aproximação amigável com os portugueses, enquanto que, na peça, a má fama dos lusitanos como cristãos que espalham a desgraça por onde passam é de conhecimento geral, conforme ilustra o excerto a seguir:

SAMORIM (Para conselheiros) - Que me dizeis?

CONSELHEIRO 1 - Estes só vêm aqui para nos roubarem. Por onde passaram, foi o que fizeram.

CONSELHEIRO 2 - Ancoram nos portos, sempre com pactos de paz, e promessas de amizade.

CONSELHEIRO 3 - São Cristãos que espalham a morte e a destruição pelos mares, com incêndios e crimes.

CONSELHEIRO 1 - Querem matar-nos, roubar as nossas riquezas...

CONSELHEIRO 2 - Vender as nossas mulheres e filhos como escravos (...)

VASCO DA GAMA - Viste o luxo do Samorim? As pedras preciosas?

ÁLVARO - Ataquemos esses sarracenos.

VASCO DA GAMA - A nossa missão é só descobrir estas terras. Depois, El rei D. Manuel enviará os homens e as armas para dominar estes cães.

DIOGO - Vão ser outros a fazerem os saques a que temos direito. (...)

VASCO DA GAMA - Havemos de voltar. Cobrar o merecido. Agora, falemos amavelmente com o Samorim. É preciso que eles não desconfiem de nada. Coelho, fica de vigia. (COSTA, 1982, p. 66).

A conversa entre os conselheiros e o Samorim evidencia a má reputação dos portugueses, cujas ações como representantes cristãos são associadas à morte, desonestidade, destruição e crimes. Esta visão remete ao paradoxo já citado na cena anterior à viagem, na qual os tripulantes do barco se propunham a espalhar a fé católica, sem serem, de forma alguma, modelo dos preceitos dessa religião. De maneira complementar, os próprios lusos demonstram uma postura inadequada para quem afirmava estar espalhando a fé, por meio da menção direta às riquezas de Samorim, considerando, inclusive, a hipótese de atacá-lo, com o intuito de roubá-lo. No entanto, recordam-se de que seu papel é descobrir as terras, para que, depois, o rei envie homens e armas que irão dominar aqueles mouros, referidos como cães.

Embora a personagem Diogo não se conforme em legar a outros o direito aos saques, o que eles, como primeiros a alcançar Calicute, supostamente, teriam direito, Vasco da Gama reafirma que haverá nova expedição, na qual irão "cobrar o merecido", preferindo, naquele momento, fingir amabilidade, para evitar desconfianças. A presença de Diogo e Coelho, nomes que remetem às personagens históricas que assassinaram Inês de Castro, vem ilustrar a qualidade dos tripulantes que embarcavam nas caravelas a fim de espalhar a Fé e o Império.

Interessante oposição estabelece-se entre a menção aos nomes dos assassinos de Inês de Castro, Diogo e Coelho, e o ideal de espalhar a fé católica pelos novos territórios descobertos, posto 
que os "missionários da fé" não são exemplos da religião que pregam. Ao contrário, seu comportamento é um antiexemplo. Espalhar a fé e o império, conforme se pode inferir a partir do comportamento das personagens na cena, é uma falácia, a partir da qual as grandes navegações portuguesas deveriam ser vistas apenas pelo viés positivo, como um ato heroico dos bravos homens que aos mares desconhecidos se lançaram.

As verdadeiras intenções dos portugueses são reveladas quando Samorim os questiona acerca dos habituais presentes que outros reinos costumavam enviar, com o intuito de estabelecer comércio. Ao perceberem que serão descobertos, os portugueses iniciam a batalha contra os mouros, fazendo refém um conselheiro de Samorim. O excerto a seguir ilustra a real imagem que os portugueses faziam dos mouros:

VASCO DA GAMA - Atirar para cima desses perros.

ÁLVARO - Mouros malditos!

VASCO DA GAMA - Façamo-nos ao largo. Eles as pagarão.

(Em cena, destruição. Mouros e alguns portugueses ficam mortos).

(COSTA, 1982, p. 67-8).

Confirmando a previsão dos conselheiros de que por onde os portugueses passavam havia destruição, após a fuga de Samorim, Vasco da Gama pede que se instale o padrão ${ }^{62}$, a fim de indicar o domínio lusitano sobre aquelas terras. Assim que se afastam os invasores, os mouros arrancam o padrão português, para apontar que aquela terra não lhes pertence, ao que segue a fala do Velho Mouro, de que: "Deviam ter sido todos mortos. Nenhum devia tornar à Pátria. Vão dar notícias que nós existimos, vão cobiçar-nos, e vêm-se vingar. Vamos sofrer durante séculos" (COSTA, 1982, p. 68). A figura do Velho Mouro, representando a sabedoria, vem acrescer à cena a sugestão de que este episódio de pretensa aproximação amigável se deu em outras muitas ocasiões e teve finais semelhantes: destruição.

No primeiro capítulo dessa dissertação, "Enredo e Personagens", quando foram trazidos à tona fatos históricos que embasam a releitura de Helder Costa, estendeu-se também a narrativa, ainda que breve, a fatos ocorridos após a União das Coroas Ibéricas, quando Portugal sofreu destruições que lhe prejudicaram em demasia, podendo-se citar: as Invasões Napoleônicas, quando D. João VI veio com sua Corte refugiar-se no Brasil; a guerra civil, entre os anos de 1826 e 1827 , que eclodiu após desavenças entre absolutistas e liberais na sucessão do governo; além, é claro, do obscuro período da ditadura salazarista, que veio a encerrar um ciclo de declínio iniciado anos antes. Neste sentido, observem-se os versos iniciais do epílogo d’Os Lusíadas: "Cantar a gente

\footnotetext{
${ }^{62}$ Marco de pedra com os símbolos das armas de Portugal, que era instalado para indicar o domínio sobre determinado território.
} 
surda e endurecida (...) no gosto da cobiça e na rudeza / Duma austera, apagada e vil tristeza" (1993, p. 387. Canto X - 145).

Helder Costa uma vez mais evidencia o aspecto negativo das navegações, sugerindo que o objetivo de espalhar a fé e o império durante esse período foi sinônimo de constantes embates gerados pela avidez por riquezas e pela necessidade de domínio e sangue que derivava dessa premissa.

\subsection{Cena II - Ato II - Camões na Índia}

Nas cenas anteriores, CHF havia sido exilado e, em virtude disso, integrou uma campanha às Índias. Registros apontam sua partida de Lisboa na expedição liderada por Fernão Álvares Cabral ${ }^{63}$ em 1553. Não há documentos que comprovem quanto tempo permaneceu em Goa, mas acredita-se que a maior parte de seu poema épico, Os Lusíadas, tenha sido escrito nesse período. Todavia, na peça, CHF une-se à expedição de Vasco da Gama, cujo maior mérito foi atravessar o Cabo das Tormentas, chegando, finalmente, a Calicute.

Neste ponto, é relevante ressaltar que o embarque de CHF na expedição de Vasco da Gama é um anacronismo da peça, que, embora justificável pela proposta de recriar uma nova concepção acerca do período das grandes navegações, não apresenta verossimilhança histórica entre os fatos narrados, tendo, dessa forma, uma personagem com cerca de trinta e cinco anos, assim mencionada na marcação de cena, que participou de eventos ocorridos há cinquenta e seis anos.

A primeira marcação de cena em Camões na Índia, título da segunda cena do ato, evidencia duas personagens históricas, respectivamente indicadas com suas idades, que eram íntimas do poeta Garcia da Orta $^{64}$, médico que dedicou a vida aos estudos botânicos e químicos das plantas da região, e Diogo do Couto, que ajudou o poeta a retornar anos mais tarde a Lisboa, na expectativa de publicar seu poema em homenagem à Pátria. Há na marcação de cena a informação de que Garcia da Orta teria por volta de cinquenta e cinco anos, sendo provável que a cena esteja ambientada entre 1556 e 1557, em Goa.

A cena começa em media res, ou seja, no meio do que parece ser a tessitura de uma estrutura narrativa por parte de Garcia da Orta, da descoberta e do domínio da Índia, mais uma vez

\footnotetext{
${ }^{63}$ Filho mais velho de Pedro Álvares Cabral.

${ }^{64}$ Médico judeu, nascido na Espanha, migrou para Portugal, de onde, sob a proteção de Martim Afonso de Souza, partiu para as Índias. Desenvolveu um dos primeiros estudos acerca das plantas medicinais daquela região. O livro Colóquios dos simples e drogas e coisas medicinais na Índia conta com um poema de apresentação de autoria de Camões, que teria sido, inclusive, seu amigo.
} 
evidenciando o anacronismo da presença de CHF na viagem de Vasco da Gama, datada de 1497, conforme ilustra o excerto:

GARCIA DA ORTA - Pois foi assim, meu jovem poeta. Tudo começou com essa grande viagem do Vasco da Gama. Há mais de 50 anos...

DIOGO DO COUTO - Mas é nossa Pátria, e a lei de Cristo, quem manda aqui!

GARCIA DA ORTA - Só se manda num sítio, se as pessoas obedecem a esse mando. Essa lei de Cristo... essa lei que devia unir os homens, e é usada para os separar.

(COSTA, 1982, p. 69).

Nota-se que Garcia da Orta expõe vasto conhecimento acerca da História das segregações causadas pela lei de Cristo, que, em princípio, deveria unir os homens, ao invés de separá-los. Considerando sua experiência de vida, o médico teve oportunidades de tornar-se profundo observador dos processos históricos que presenciou, os quais se encontram explícitos em suas falas e biografia:

GARCIA DA ORTA - Foi a Inquisição que me deu a consciência que o homem pertence ao Mundo inteiro, e não é só de um recanto qualquer onde nasceu. A minha família andou sempre de arcas às costas, a fugir às fogueiras. Felizmente, não tenho razão de queixa... estou rico com os meus negócios de drogas e pedras preciosas... não se esqueçam que sou mesmo judeu a sério.

(...) Olha, os judeus fingem que são católicos, mas jejuam às escondidas. Aos sábados metem roupa limpa e camisa lavada, não trabalham... (...) Se for preciso não saímos da toca, somos com a lebre a espreitar o caçador. (COSTA, 1982, p. 6970).

Originário de uma família judaica e graduado em Medicina, conviveu permanentemente com a perseguição antissemita, fato esse que o obrigou a mudar-se para as Índias, como médico particular de Martim Afonso de Souza ${ }^{65}$, almejando escapar das garras afiadas da Inquisição, que se instalava em Portugal. Mesmo com a partida de seu protetor, por volta de 1541, optou por permanecer ali, com o intuito de desenvolver seus estudos botânicos, que lhe renderam sua obra prima: Colóquios dos simples e drogas e coisas medicinais na Índia, que tem por tema a detalhada descrição dos possíveis empregos da vegetação da região, com vista à cura de diferentes doenças. A riqueza de detalhes e a coerência botânica da flora do episódio da Ilha dos Amores (Canto IX e X) em Os Lusíadas podem ter sido motivadas pela convivência de CH com Garcia da Orta.

O médico viria a falecer no ano de 1568, aos sessenta e sete anos. Em vida, não tivera que enfrentar o Tribunal do Santo Ofício, porém, após a morte, sua família foi duramente perseguida e

\footnotetext{
${ }^{65}$ Nomeado capitão-mor marítimo e, mais tarde, governador da Índia.
} 
condenada, chegando, inclusive, a ser feita a exumação de seus restos mortais, para serem queimados na fogueira, em sinal de "retaliação".

Garcia da Orta alerta para a universalização ${ }^{66}$ dos povos segregados pelas diferenças de crença. O tratamento destinado aos judeus, ou mesmo aos cristãos-novos, não era dos mais amistosos ao longo da História dos Países Ibéricos, conforme corrobora o historiador José Hermano Saraiva:

Em 1492, os Reis Católicos decretaram a expulsão dos judeus dos seus Estados (Aragão e Castela) no prazo de quatro meses e sob a pena de morte. Muitos judeus castelhanos procuraram refúgio em Portugal. D. João II autorizou a instalação das famílias mais ricas a troco de altas quantias. Mas os refugiados eram uma verdadeira invasão: cerca de cem mil. O rei autorizou-os, também mediante uma propina por cabeça, a ficarem oito meses em Portugal seguindo depois os seus destinos. Os que nada puderam pagar foram reduzidos a escravos.

A maior parte dos refugiados ficou no País, engrossando enormemente a população judaica, que já era numerosa. Muitas crianças, retiradas à força aos pais, foram mandadas povoar a Ilha de S. Tomé. Poucos sobreviveram.

Em 1496, D. Manuel seguiu o exemplo dos Reis Católicos; ordenou a expulsão de todos os judeus, tanto os castelhanos como os portugueses. Fê-lo por exigências no decurso das negociações com a filha dos monarcas do país vizinho; mas parece que os seus conselheiros se deram conta dos prejuízos que a medida acarretava: perda dos enormes produtos que os judeus pagavam; sangria dos valores que levariam consigo, saída de milhares de úteis artesãos. $\mathrm{O}$ rei adoptou uma política de compromisso aparente: os judeus ficavam, mas deixavam de ser judeus. Para o conseguir, ordenou o baptismo forçado dos filhos, recusou meios de transporte para a saída por mar (o que equivalia à proibição de sair, por a passagem por Espanha não ser possível) e deu a todos a garantia de que, durante vinte anos, não seriam perseguidos por motivos religiosos. Era portanto a imposição da conversão aparente e uma forma de iludir a obrigação contraída nos acordos com os Reis Católicos.

As judiarias foram extintas, as sinagogas transformadas em Igrejas, os judeus passaram, oficialmente, a ser cristãos. Para distinguir uns dos outros, passou a falar-se de cristãos-novos e de cristãos-velhos.

O problema dos cristãos-novos iria arrastar-se durante muito tempo. A fusão entre os dois grupos, que durante séculos tinham vivido separados, foi lenta e difícil. Em 1506 houve em Lisboa motins em que os cristãos-novos foram ferozmente perseguidos. O número de mortos foi cerca de dois mil. Apesar da garantia de não perseguição, os hebreus foram objecto de numerosas descriminações. À antiga distinção da população em duas nações, cristã e judaica, que permitiu aos judeus viver em paz durante séculos, sucedeu-se uma falsa unidade. A partir de 1434, as perseguições foram constantes e sistemáticas elevaram à formação de duas mentalidades viciosas e inimigas: a do cristão-velho detentor da verdade, inimigo da inovação, farejador de erros alheios, dogmático e repressivo, e a do cristãonovo, dissimulado, messianista, acossado, intimamente revoltado, não solidário com o conjunto da comunidade nacional que o repele e que ele no fundo não reconhece como sua. Essa fractura da consciência nacional chegaria até muito tarde. (1996, p. 131-3).

\footnotetext{
${ }^{66}$ Utiliza-se o termo como sendo o oposto à nacionalização.
} 
Ao que parece, o catolicismo tornou-se um escudo de proteção contra as intolerâncias da Inquisição, cuja pena aos "hereges" quase sempre consistia na fogueira e na apropriação dos bens por parte do Estado e da Igreja. A necessidade de ser católico acentuou ainda mais a adoção da religião por conveniência, e não por fé. Processo semelhante se desenvolveu durante a colonização do chamado "Mundo Novo", quando os colonizadores buscaram "civilizar" os nativos por meio da imposição de sua cultura e religião.

O espírito inquisitorial não se deteve apenas na Metrópole, chegando também às Índias, no ano de 1565, conforme indica o diálogo entre o médico e Camões:

ESCRAVO - Senhor... Senhor... Notícia má, coisa má.

GARCIA DA ORTA - Que foi? Fala, rapaz.

ESCRAVO - Dizem que vão pôr a Inquisição na Índia. Dizem que há muitos herejes. Tenho medo, senhor, tenho medo.

GARCIA DA ORTA - Já esperava isso há muito tempo. Eu não tenho problemas. Sou rico, posso pagar minha tranqüilidade e pureza de alma. Meus amigos, saiam daqui. Andamos sempre juntos, os denunciantes não esquecerão os vossos nomes. Pelo menos tu, Camões... O Diogo ainda é um franganito...

CAMÕES - Para onde?

GARCIA DA ORTA - Para África... Ou para um país de herejes... Não te tratam mal... São mais tolerantes. (COSTA, 1982, p. 83).

Garcia da Orta atribui seu dinheiro e posição à tranquilidade de que desfruta naquele lugar, pensamento que se comprovará equivocado, quando, ao final da peça, se fará menção ao episódio de exumação do corpo do médico, com o intuito de puni-lo por ter sido judeu em vida. Em conversa entre CHF, Diogo do Couto e Garcia da Orta, CHF compara-se aos judeus, em função das perseguições que esses sofriam, mesmo não sendo um deles. O bardo demonstra o desejo de ser estimado, e o amigo lhe retruca que o caminho desse reconhecimento se deve a "falar sempre a verdade", ao que o poeta responde ser essa sua forma de escrita desde El-Rei Seleuco, como menciona Diogo do Couto.

O pensamento é entrecortado pelo convite para jantar, a ser realizado dentro de alguns dias, com a cena concentrando-se em outros aspectos da vida de CHF nas Índias. Após o jantar com os amigos mais chegados, as personagens de Diogo do Couto e CHF seguem para um bordel, onde há um diálogo com as prostitutas portuguesas que lá se encontram. Essas são questionadas no que diz respeito ao sucesso de sua viagem, ao que respondem ter feito excelente escolha vindo à Índia, visto que não têm concorrência, apenas das “pretas". Nas falas das marafonas, é possível notar certo tom de desdém em relação às mulheres nativas do lugar, estabelecendo-se uma espécie de hierarquia entre as que pertencem ao lugar e as que são estrangeiras e que, por seus modos, são mais valiosas e dignas. 
O diálogo é interrompido pela ação de um soldado, que ataca uma moura, a qual o rejeita, ao que intervém outro mouro, que tenta dissuadir o soldado de possuir a moça à força, como ilustra o excerto:

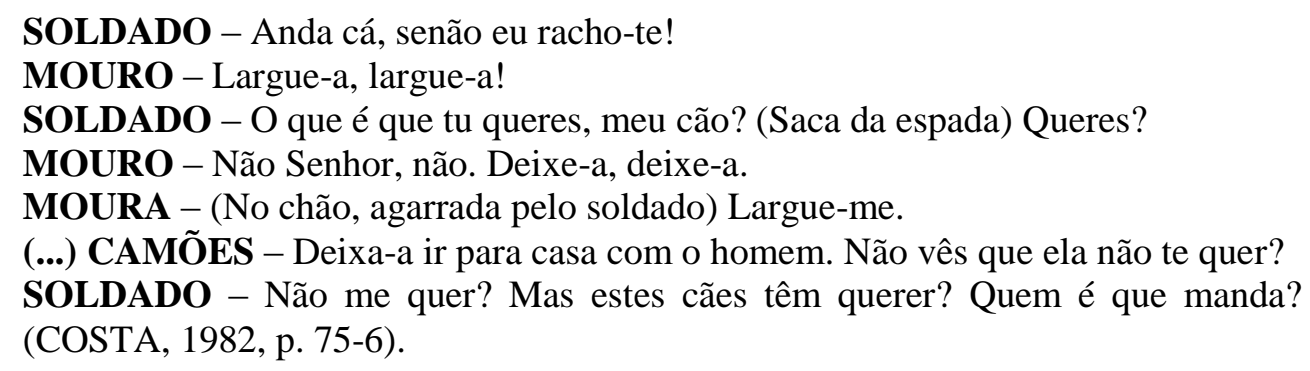

Nesse ponto da cena, estabelece-se novamente o contraste entre a figura do $\mathrm{CHF}$ frequentador de bordéis e o homem de princípios, que liberta a mulher em perigo. Na cena Camões na Índia, são retratadas diversas facetas do poeta, até que se configure o vate maduro, autor do célebre poema épico, cujo mote é eternizar, por meio de sua arte, o ilustre feito da viagem de Vasco da Gama na História Portuguesa.

Ainda nessa cena, CHF e Bárbara, possivelmente uma amante do poeta, conversam a respeito do fazer poético, ao que $\mathrm{CHF}$ responde tratar-se, em grande medida, de fingimento, e não do sentimento real acerca do que se escreve. Estabelece-se evidente diálogo com o poema Autopsicografia, de Fernando Pessoa, no qual esse atribui o fazer poético ao fato de o poeta ser um fingidor e, portanto, capaz de simular com perfeição em seus versos os sentimentos que não está a sentir.

Por CHF destoar de $\mathrm{CH}$, aquele tem consciência do processo de afastamento entre o autor e sua obra, o que, em última análise, evidencia uma característica predominante na modernidade: a fragmentação do sujeito, que, nesse caso, se deve ao fato de CHF ser fruto do atrito que ocorre na inserção de $\mathrm{CH}$ no texto teatral de Helder Costa, no qual predomina a mundividência contemporânea, representada no palco por $\mathrm{CHF}$, que se passa por $\mathrm{CH}$.

Na sequência da mesma cena, ocorre um diálogo entre Garcia da Orta, Diogo do Couto e CHF, que se mostra descontente com a vergonhosa ação dos portugueses em terras indianas, conforme é ilustrado pelo excerto:

GARCIA DA ORTA - E os Espanhóis, e os Holandeses? Cuidado, não comeces a não gostar do teu sangue... Não te esqueças que hoje se sabe mais num dia com os portugueses, que dantes se aprendia em cem anos com os Romanos...

CAMÕES - Para que serve o trabalho que estou a ter com Os Lusíadas? Para quê tanto estudo e tanto esforço? 
GARCIA DA ORTA - Com a tua Arte, tu podes explicar o ideal, o sonho, e dar beleza a tudo o que nós, homens da Ciência, descobrimos e tentamos divulgar. Se fizeres isso, toda gente vai conhecer o nosso trabalho, vai perceber a nossa utilidade. És o mais belo arauto que os homens como eu, agarrados a livros, a experiências, a teimosias, podem desejar: consegues tirar-nos a secura do pensamento, e pôr-nos a mesa com o povo.

CAMÕES - Já estou a escrever sobre as tempestades, a tromba de água, os ventos... é a experiência do medo que apanhei na viagem... Quero falar das plantas, dos frutos, das drogas que descobriste... (COSTA, 1982, p. 80-1).

Nesse trecho da cena, revela-se a mundividência de Helder Costa por meio de CHF, inferindo-se que Os Lusíadas foi o resultado do relato da viagem na qual o vate tomou parte, na expedição de Vasco da Gama, embora, na fala de Garcia da Orta, a expedição teria ocorrido há cinquenta anos, sendo, portanto, impossível que o bardo tivesse participado de tal empreitada. Porém, do ponto de vista ficcional, trata-se de anacronismo, por meio do qual se atribui verossimilhança ao texto teatral.

Há em Os Lusíadas a predileção pelo aspecto laudatório das navegações ultramarinas portuguesas, narrando-se, nesse poema, amor incondicional à Pátria, independente das injustiças e atrocidades feitas pelos homens, pois de maior valor é a nação. Tal direcionamento na epopeia é ficcionalizado na cena em que um escravo comunica que a Inquisição será instaurada na Índia. Portanto, a cena possivelmente está ambientada em 1565. CHF amaldiçoa Portugal, ao que é repreendido por Garcia da Orta, que lhe ensina a separar a Nação das pessoas que dela fazem parte.

CAMÕES - Maldito Portugal!

GARCIA DA ORTA - Não, Luís Vaz!

Acusa as injustiças e prepotências dos governantes, denuncia a Igreja mistificadora, ataca a barbárie da Inquisição, combate a ignorância e o medo, mas ama tua Pátria.

Nós mostramos novos Mundos ao Mundo, e muitos de nós, os que acreditam na mudança das coisas, querem o amor e a paz, entre todas as raças.

É uma luta que dura há séculos.

Precisamos de poetas que saibam cantar...(COSTA, 1982, p. 83-4).

Nesse momento, Garcia da Orta menciona o princípio fundamental que teria norteado a escritura d'Os Lusíadas: o amor incondicional à Pátria, ainda que o poeta se deparasse com um mundo bastante diverso daquele cantado em sua epopeia. Embora possa parecer um tanto contraditório a adoração da Nação, tendo em vista os constantes desapontamentos advindos dela, Garcia da Orta sugere que o sentimento nacionalista seja superior a todas as manifestações negativas daqueles que governavam a Nação. Independente de quão grosseiros ou falhos fossem os erros, nada poderia ser capaz de macular a honra da Pátria em si. Propõem-se, desse modo, duas esferas para validar os julgamentos sobre a Nação: aquela sobre a qual há reclamações e protestos, 
tratando-se dos elementos que a compõem, tais como governantes, injustiças políticas e religiosas, e outra esfera, sobre a qual repousa a perene e imutável Pátria, cuja essência está em seus filhos ilustres. Segundo o médico, a escrita era o modo encontrado para "explicar o ideal, o sonho, e dar beleza a tudo o que nós, homens da Ciência, descobrimos e tentamos divulgar" (COSTA, 1982, p. 80). Deste modo, caberia a CHF, por meio de sua arte, conceder a merecida importância ao trabalho que os ilustres filhos da Nação faziam, mesmo longe de seu seio.

O valor da eternidade por meio da arte era tão culturalmente arraigado nas sociedades desde a invenção da escrita, que essa seria a grande razão para a terem inventado. Isto se reflete na fala de Garcia da Orta, quando pede a CHF que faça a apresentação de seu livro, que trata de drogas medicinais.

GARCIA DA ORTA - Luís, vai ser impresso o meu livro sobre plantas e drogas. Para verdes a importância que dou à poesia, não peço a nenhum sábio que me faça a apresentação do livro... escreve uns versos... (COSTA, 1982, p. 81).

O vate, sob esta perspectiva, teria em suas mãos o poder de tornar eterno aquilo que sua arte se propusesse a cantar, no caso d'Os Lusíadas, a grandeza dos filhos da Pátria portuguesa. Em oposição a essa visão épica das expedições ultramarinas, a figura de Diogo do Couto dará voz, em seu livro $O$ Soldado Prático, a um olhar pessimista acerca das investidas marítimas, de modo a colocar-se em posição oposta a $\mathrm{CH}$ com relação às benesses que o processo das expedições teria trazido ao povo português, como se pode ver no excerto abaixo:

DIOGO DO COUTO - Quero saber de tudo. A Índia dá-me cabo da cabeça! Ainda hei-de escrever esta história toda!

CAMÕES - Escreve a nossa triste história de soldados. A nossa prática. (COSTA, 1982, p. 81).

O termo "prática" remete à experiência vivida pelo soldado em seu percurso pela Índia, o qual será refletido em seu livro $O$ Soldado Prático, cujo argumento principal da narrativa se desenvolve a partir do diálogo entre o Soldado, o Despachador e o Fidalgo, quando o primeiro vai à casa do segundo para entregar sua petição e os papéis que atestavam os longos anos de serviços prestados na Índia em nome do Rei. Iniciam-se longas reflexões a respeito das condições a que os soldados originários de famílias pouco favorecidas eram submetidos, tais como fome e abuso de poder, além da desonestidade dos nobres que ocupavam posições privilegiadas no governo indiano e, em virtude disso, tiravam vantagens e deixavam em segundo plano os interesses da Coroa. A 
narrativa trata dos enganos e desenganos das Índias, creditando a lealdade do serviço real aos valores morais do indivíduo, e não à sua origem de nascimento. M. Rodriguez Lapa, no prefácio da obra de Diogo do Couto, afirma que esse:

(...) emite opiniões, que visam a demonstrar a superioridade dos méritos e serviços pessoais sobre a fidalguia do nascimento (...) e insurge-se contra a perigosa mania do tempo, que define nos seguintes dizeres: 'homem que não é fidalgo, não é chamado pêra nada' (...) Temos pois em Diogo do Couto o exemplo do servidor, que se vê embaraçado na vida e tolhido de medrar por não ser de casta fidalga. (COUTO, Diogo do. 1980. Prefácio. p. 2).

De um lado, $\mathrm{CH}$ emprega sua arte para eternizar a glória da Pátria, concretizada pelos grandes feitos dos portugueses. Seu argumento concentra-se na perenidade das conquistas, que confeririam, por si só, um lugar majestoso à Nação e a seus filhos. Por outro lado, Diogo do Couto considera as expedições marítimas às Índias como um grande engano, não só pelas inúmeras perdas, mas também pelo péssimo tratamento destinado àqueles que, de fato, concederam a Portugal um lugar de destaque. O principal argumento do livro gira em torno da diferenciação no tratamento que se dava a homens nobres, que gozavam de posições privilegiadas na sociedade. Esses eram mais bem alimentados, amparados quando em batalhas e dispunham de certa garantia de ser nomeado para altos cargos no comando ou na administração dos soldados, que eram submetidos a carestias de alimento e de cuidados médicos, sendo-lhe legados os trabalhos mais penosos e desgastantes, em virtude de sua origem mais simples.

Assim, tendo em vista o afastamento do objeto de análise como recurso imprescindível para tratar melhor um assunto, Helder Costa se apropria tanto da obra de Camões quanto da de Diogo do Couto, sendo o ponto de partida comum a ambas a experiência das empreitadas portuguesas no além-mar. Embora as visões não sejam convergentes com relação ao assunto tratado, uma vez que $\mathrm{CH}$ revela uma visão positiva com relação às expedições, ao passo que Couto as representa como fonte das mazelas sofridas pelo Império, o encenador português contemporâneo Helder Costa acresce a essas mundividências a sua própria, cujo cerne repousa na ideia de um teatro de conscientização política acerca da situação do País nos dias atuais a partir da análise dos erros do passados. Logo, cria-se uma nova Viagem, em que personagens históricas são reconstruídas ficcionalmente a partir da visão de Helder Costa e circundadas por finos fios de História, ficção e diálogos intertextuais literários de várias ordens, que servem para atribuir maior verossimilhança às personagens dentro da peça, bem como para a reconstrução da imagem que se tem das navegações ultramarinas portuguesas enquanto ponto basilar da decadência que o país alcançou a partir de então. 
Do fim do apogeu até a declarada decadência, as conquistas ultramarinas são representadas como uma sucessão de interesses de diversas camadas de poder do governo português, cuja importância histórica foi configurada de tal modo na psique portuguesa, que se tornou sinônimo do período áureo desta nação, embora nem toda a população gozasse das inúmeras conquistas adquiridas, compartilhando, no mais das vezes, somente os prejuízos. Assim, observa-se que, a partir do momento em que as expedições ultramarinas cessaram, evidenciou-se ainda mais a decadência da Nação Portuguesa, culminando com a perda de sua independência política. Desse modo, o período áureo português passou a ser considerado uma espécie de "porto seguro", para onde todos os olhares convergiam, resultando num engessamento político e psicológico, na medida em que se acreditava que a solução para os problemas estaria no tempo em que Portugal havia sido o centro do mundo, perdendo-se de vista o presente e, consequentemente, o futuro dessa Nação mergulhada na nostalgia de um glorioso passado.

\subsection{Cena III - Ato II - A Peste}

Ambientada por volta de 1570 , essa cena se passa quando CHF já havia retornado a Portugal, após muitos infortúnios no Oriente, dentre os quais se destacam a pobreza, companheira inseparável do poeta, e o naufrágio na foz do Rio Mekong, onde supostamente o poeta teria perdido sua lendária companheira Dinamene, ao preteri-la para salvar seu poema épico. Não se pode afirmar com segurança o que o vate teria feito durante os dezessete anos em que esteve no Oriente, porém, segundo Alexei Bueno, no prefácio da epopeia de $\mathrm{CH}$, este, ao chegar à Índia:

Ao que tudo indica participou de uma expedição ao Malabra e de outra ao estreito de Meca. Vagueou pela Índia e pela China, sempre perseguido pela pobreza, apesar da popularidade granjeada por seu engenho poético e valor pessoal. Naufragou na foz do rio Mekong, salvando a nado os originais de sua epopéia, como narra na estrofe 128 do último canto, morrendo porém no mesmo naufrágio uma sua amante chinesa (...) Em certo momento, promessas de trabalho o levaram para Moçambique, sem nada no entanto ter se concretizado, e onde inclusive chegou a ser preso por dívidas de viagem. Lá o vai encontrar Diogo do Couto, 'tão pobre que vivia de amigos' tendo sido necessária uma cotização dos mesmos para the pagarem o retorno a Portugal, onde chegou a 7 de Abril de 1570. (CAMÕES, 1993, p. 3).

Assim que retornou à Pátria, CHF teria buscado apoio financeiro da família de Vasco da Gama, uma das personagens principais de seu poema, para publicar sua obra. No entanto, essa não demonstrou interesse em ajudá-lo. Ao final da cena, alguns poetas da Corte, dentre os quais se 
destacam Sá de Miranda ${ }^{67}$, Pedro de Andrade Caminha e António Ferreira ${ }^{68}$, referem-se, de maneira sarcástica, à condição de CHF após seu retorno do Oriente, sugerindo que a pobreza em que o poeta se encontrava era resultado de suas péssimas escolhas, tais como afastar-se da proteção da Nobreza e levar uma vida desregrada, ambas possíveis causas do exílio do vate, segundo o excerto a seguir:

ANTÓNIO FERREIRA - (...) Eu exercito muito o latim, preocupo-me com as regras da escrita, para mim o género teatral puro é a tragédia, nunca encontrei esse senhor nestes saraus, julgo que corria alcouces e tabernas em companhia desse frade devasso, o Chiado, suponho que gostaria das versejadelas do nosso pobre ourives Gil Vicente... (...)

SÁ DE MIRANDA - Não é fidalgo de valor.

PEDRO ANDRADE DE CAMINHA - Isso não é o mais importante. O pior é que ele pensa, o que ele sempre fêz...

DIOGO BERNARDES ${ }^{69}$ - Zombava dos poetas da Corte... Veio miserável da Índia... ah!ah!ah!

ANTÓNIO FERREIRA - Ouvi dizer que voltou, há tempos, e que quer publicar o tal livro...

PEDRO ANDRADE DE CAMINHA - Isso ainda se vai ver. A Inquisição não se deixa enganar

(COSTA, 1982, p. 89-90).

António Ferreira ressalta em sua fala que jamais encontrou com CHF nos saraus da Corte, e isso se devia ao tipo de companhia com quem CHF deveria estar, de gente "desqualificada" como o padre Chiado. Segundo a peça, o poeta era um frequentador do Mal-Cozinhado, e ambos apreciariam os trabalhos de Gil Vicente, que, embora fora protegido pela rainha-mãe Leonor e falecido há anos, não era bem visto pelos membros da Nobreza. Nota-se o tom de deboche na fala de Diogo Bernardes ${ }^{70}$ ao apontar que CHF, no passado, zombava dos poetas da Corte, e agora se encontrava em situação miserável. Nova troça ocorre quando Pedro de Andrade Caminha assinala a dificuldade de se publicar algo naquele período histórico, especialmente porque toda publicação requereria passar a aprovação da Inquisição.

Em seu retorno a Portugal, $\mathrm{CH}$ se deparou com um país completamente distinto daquele que havia abandonado. D. João III faleceu em 1557, deixando como sucessor seu neto, ainda pequeno, D. Sebastião. Enquanto esse não atingia a maioridade, D. Catarina de Aragão, viúva do rei, seguida pelo Cardeal D. Henrique, de 1562 a 1568, governaram Portugal em nome do príncipe herdeiro.

\footnotetext{
${ }^{67}$ Poeta português que teria sido responsável por divulgar em Portugal a medida nova, advinda do resgate da tradição clássica.

${ }^{68}$ Poeta e dramaturgo português que se destacou pela escrita de Castro, releitura do episódio histórico que envolveu D. Pedro, filho do monarca Afonso IV, e Inês de Castro.

${ }^{69}$ Poeta português acerca do qual, ainda hoje, pairam dúvidas a respeito de possíveis plágios entre ele e Luís Vaz de Camões.

${ }^{70}$ Poeta contemporâneo a $\mathrm{CH}$.
} 
Aos catorze anos de idade, D. Sebastião foi emancipado, tomando para si a função de representante da Monarquia Portuguesa, até o ano de 1578, quando desapareceria na batalha de Alcácer Quibir.

Devido à pouca experiência de vida do neto, a rainha D. Catarina teria nomeado como confessor e escrivão os irmãos Luís e Martim Gonçalves Câmara, cuja influência sobre o rei é parodiada na peça, sugerindo que o monarca, D. Sebastião, não tinha voz de comando, sendo representado como um boneco nas mãos de seus conselheiros. Os irmãos Câmara manipulavam de modo grosseiro as decisões tomadas pelo monarca, empregando sua influência para direcioná-las de forma favorável a seus interesses particulares e aos de Espanha, como é possível ilustrar no excerto a seguir:

(...) Surge um trono onde está um boneco representando El-Rei D. Sebastião. Atrás do trono, de cada lado do Rei, estão os irmãos Câmaras, um o padre confessor (designado por Câmara 1), outro o vedor de justiça (Câmara 2). Estão presentes conselheiros, damas e fidalgos).

CÂMARA 1 - Não é aconselhável voltar para Lisboa. A peste continua a ceifar pobres vidas...

CÂMARA 2 - Sua Alteza tem defendido muito bem, nestas serranias, a sua Real Saúde... As caçadas e os jogos de cavalaria estimulam a valentia e a coragem... (...)

D. JERÔNIMO OSÓRIO ${ }^{71}$ - A fidalguia está arruinada, as nossas jóias estão empenhadas, as mulheres sofrem e choram, o povo não pode sacrificar-se mais.

CÂMARA 2 - Cobarde!

D. JOÃO DE MASCARENHAS ${ }^{72}$ - Alteza! Se quereis insistir nessa louca aventura de África, levai convosco a mortalha...

CÂMARA 1 - Velho! Tonto!

CÂMARA 2 - Cobarde!

CÂMARA 1 - (Ajoelha-se, e mostra uma seta com a ponta vermelha) - Eis aqui uma seta do mártir D. Sebastião. Foi enviada de Roma, por Sua Santidade o Papa, a El-Rei D. Sebastião, como prova de concordância e respeito pela missão evangelizadora que Portugal terá de cumprir em África. (COSTA, 1982, p. 86-7).

Além de todos os problemas econômicos e políticos que assolavam o reino, Portugal ainda passava por uma epidemia de peste, à qual se refere o título da cena. Acredita-se que o primeiro surto de Peste Negra tenha ocorrido em 1347 na Europa, chegando a Portugal no ano seguinte. Cerca de metade da população teria morrido em função da enfermidade, que se prolifera por meio do bacilo Pasteurella pestis, cuja transmissão se dava tanto pela picada de pulgas vindas de ratos portadores do micro-organismo quanto pelo contato com alguém já contaminado. A epidemia de Peste a que a peça se refere ocorre no ano de 1569, em Lisboa, Portugal. Gilberto Cotrim (1996)

\footnotetext{
${ }^{71}$ O Bispo de Algarve não desaprovava a ideia de uma nova cruzada, porém não acreditava que se tratasse do melhor momento para a empreitada.

${ }^{72}$ Nobre fidalgo que serviu ao rei durante longo período na Índia.
} 
estima que tenham morrido cerca de seiscentas pessoas por dia durante o período, daí a atmosfera fúnebre que é representada no início da cena:

(Em cena, na penumbra, corpos cobertos com lençóis brancos. Sai fumo de barricas. Ouve-se uma ladaínha religiosa acompanhada por sinetas. Surge uma procissão para esconjurar a peste. Um homem cai, a um canto.).

PADRES - Kyrie eleison

Christie eleison

Kyrie eleison

Christie, audi nos,

Christie, exaudi nos,

Pater de coelis Deus, misere nobis ${ }^{73}$ (COSTA, 1982, p. 85).

No excerto acima, a oração em latim evoca a piedade para aplacar a Peste, que dizimava a população. Porém, nem mesmo aqueles que se mantêm em oração são "protegidos". Dessa feita, algumas personagens que representam uma voz coletiva julgam a epidemia como uma espécie de punição aos pecados, seja pela violação da ordem teocêntrica de mundo, seja pela perseguição aos judeus, como se pode observar no excerto a seguir:

MULHER DO POVO 1 - É maldição! É castigo de Deus pelos pecados que temos feito... (...) Vamos morrer todos... Não temos salvação!

MULHER DO POVO 2 - É o castigo do que andámos a fazer pelas Índias e pelas Áfricas... Morreu a Família Real... É pelas fogueiras que acenderam a queimar judeus... (...)

MULHER DO POVO 1 - O que é feito de El- Rei D. Sebastião? Onde está nosso Rei? (COSTA, 1982, p. 85-6).

A última fala da mulher do povo permite duas formas de interpretação. A primeira delas apresenta-se como uma queixa em torno da ausência constante de D. Sebastião na capital do reino, especialmente agravada pelo fato de o rei abandonar a cidade para abrigar-se da Peste, deixando para trás o povo, que depositava nele as esperanças de mudar os rumos da decadência em que Portugal se encontrava. No entanto, outra possível interpretação revela que a queixa pode remeter à ausência de um rei que de fato governe, impondo-se como pulso forte, e não um joguete nas mãos de seus conselheiros. Em ambas as leituras, a figura do rei D. Sebastião é associada à grande decepção popular, visto que se acreditava que $O$ Desejado, além de livrar Portugal da sombra da União das Coroas Ibéricas sob o domínio espanhol, reconduziria o país a seus dias de glória,

\footnotetext{
${ }^{73}$ Senhor, tende piedade de nós. Cristo, tende piedade de nós. Senhor, tende piedade de nós. Cristo, ouvi-nos. Cristo, atendei-nos. Pai do Céu, que sois Deus. Tende piedade de nós.
} 
embora, como já foi mencionado, esse período ufanista é assim considerado não por seu significado real, mas porque foi assim assimilado ao imaginário coletivo lusitano.

Helder Costa procura apontar, ao longo de cada cena, que o valor áureo atribuído às expedições ultramarinas não se deve às descobertas portuguesas ou à prosperidade econômica que o país viveu, mas sim ao peso que esse período representa na psique portuguesa, uma vez que, por isso, está associado ao tempo em que Portugal foi muito além de um pequeno país, mas o dono do mundo que se conhecia até então.

\subsection{Cena IV - Ato II - A censura}

Após a instalação da Inquisição em Portugal ${ }^{74}$, em 1536, durante o reinado de D. João III, a Igreja Católica foi ganhando maior autoridade, seja por meio da eleição de representantes, que interferiam na governança dos monarcas, como no caso de D. Sebastião, sob a influência dos irmãos Câmara, ou, ainda, na união máxima entre o poder político e o religioso, centralizado na figura do Cardeal D. Henrique, Inquisidor mor e sucessor de D. Sebastião, na falta de herdeiro mais próximo do Rei.

Assim, para que um livro fosse publicado, esse deveria conseguir duas concessões, uma real e outra inquisitorial, visando à manutenção da ordem vigente, de modo a evitar possíveis incitações contra o Estado e a Igreja. A respeito da dificuldade de se conseguir uma licença em tempos de Inquisição, Arthur Anselmo assinala como transcorreu dificultoso o processo de autorização para a publicação d'Os Lusíadas:

Quando, em 1572, o dominicano Bartolomeu Ferreira redige a licença inquisitorial da primeira edição d'Os Lusíadas, vigoram em Portugal o Rol dos Livros Defesos de 1561, que Francisco Foreiro (também dominicano) elaborara por ordem do Cardeal Infante, e o Index de Librorum Prohibitorum de 1564, cópia do índice tridentino, cuja publicação fora igualmente fora promovida por Foreiro. (...)

Em 1561, aperta-se a físcalização dos barcos chegados do estrangeiro, com o fim de se impedir a difusão de livros não autorizados. Paralelamente, assiste-se ao crescimento tentacular das competências da Inquisição, não só em matéria de heresia (1561), mas também em questões menos complexas, como os delitos de sodomia (1562), mediante a supressão da jurisdição episcopal nessas áreas, doravante inseridas no feudo inquisitorial. (...) Pouco antes da publicação d'Os Lusíadas, o Conselho Geral do Santo Ofício ordena que a censura dos livros seja confiada aos 'revedores' diminuindo, assim, a autoridade dos inquisidores nesta matéria. A decisão, tomada em 1570, é acompanhada no ano seguinte de novas disposições contra os possuidores de livros heréticos. (ANSELMO, 1982, p. 34-5).

\footnotetext{
${ }^{74}$ A instalação da Inquisição foi pedida pela primeira vez por D. Manuel, em 1515, em cumprimento ao acordo de casamento com D. Isabel de Aragão, sua primeira esposa, católica fervorosa. Porém, o pedido não foi aceito, sendo refeito, em 1531, por D. João III. O Tribunal do Santo Ofício começou a vigorar em Portugal em 1536.
} 
Tendo em vista o árduo caminho percorrido por CHF até que sua epopeia fosse publicada, essa cena trata do encontro entre o vate e o padre Bartolomeu, Inquisidor responsável pela leitura do manuscrito do poeta. Logo de início, o clérigo demonstra peculiar interesse na formação religiosa do bardo, evidenciando que a resposta influenciará na apreciação do poema, conforme ilustra o excerto a seguir:

\footnotetext{
P. BARTOLOMEU - Frequentais as aulas da Igreja de S. Domingos? CAMÕES - Lá me arranjo, padre! BARTOLOMEU - É bom. Matais saudades da vossa infância... CAMÕES - Muito me serviu para minha arte. (COSTA, 1982, p. 91).
}

Diante da réplica satisfatória, na qual o poeta atribui sua arte ao que aprendeu nas aulas de religião, o Inquisidor direciona seus comentários ao que deveria ser modificado na obra, por meio da expressão "Temos aqui umas coisas a modificar". Porém, CHF assume postura defensiva diante da possibilidade de que seu poema, trabalho de uma vida, fosse mutilado, ao que recebe como réplica o aviso de que o poeta deveria se entender com o Inquisidor, caso quisesse ver seu livro publicado.

P. BARTOLOMEU - Era bom que nos entendêssemos. Conheceis o grande poeta Pedro Andrade de Caminha?

CAMÕES - Sim.

P. BARTOLOMEU - Não tem essa arrogância... (Puxa de um papel) Tem consideração pelas minhas funções... (Lê):

Para poderem ser de ti aprovados

Meus versos, e de todos bem ouvidos,

Devem primeiro ser de ti emendados,

Com mão de amigo e com cuidado lidos.

Serão com tua lima confiado,

Com tua aprovação bem recebidos;

Daquela ficarão cultos e puros,

Com esta poderão correr seguros.

Reparais na diferença de comportamento?

Porque é que se chama 'Lusíadas'? (COSTA, 1982, p. 91-2).

Ao atribuir arrogância à atitude de CHF no que concerne às modificações de sua epopeia, o Inquisidor exemplifica o comportamento esperado quando menciona Pedro de Andrade Caminha, rival do vate. Em outra oportunidade, é evidenciado o caráter servil do poeta, na tentativa de agradar a quem estava no poder, garantindo, com isso, prestígio e proteção. 
Segue-se a esse breve desentendimento a leitura já pouco interessada do padre e alguns questionamentos acerca do título da obra, a referência aos símbolos pagãos e ao que o padre acredita ser o grande empecilho à publicação, o episódio da Ilha dos Amores.

P. BARTOLOMEU - Eu vou alterar algumas estrofes... Para tentar que isto seja publicado... Esta Ilha dos Amores...

CAMÕES - A Ilha dos Amores é uma homenagem ao valor dos Portugueses, élhes oferecida a Ciência, o conhecimento, o amor, é a ascenção dos mortos à imortalidade... (COSTA, 1982, p. 92).

P. Bartolomeu Ferreira vê na Ilha dos Amores a menção aos símbolos pagãos e o estímulo a condutas pecaminosas contra a soberania da religião católica, ao que CHF responde tratar-se apenas da representação simbólica da vitória dos portugueses, cuja recompensa teria sido a Ciência, trazida pela visão da Máquina do Mundo, consolidando, assim, a perenidade das conquistas lusitanas. Como ilustração à argumentação desenvolvida por Camões na epopeia, desenvolvem-se cenas da Ilha dos Amores, sem, no entanto, representar cenas de brutalidade ou pornografia, as quais, evidentemente, chocariam o Inquisidor.

Ao representar o episódio da Ilha dos Amores, com todos os seus símbolos pagãos, uma clara glorificação ao sistema ptolomaico, CHF convence o Inquisidor de que se trata apenas de referências a símbolos clássicos. Para tanto, argumenta que o conhecimento de mundo oferecido a Vasco da Gama é de cunho geocêntrico, ou seja, está de acordo com os princípios defendidos pela Igreja Católica e, por isso, o poema não apresenta nada que se opusesse à religião e às crenças por ela professadas. Dessa feita, adveio o documento que autorizava a publicação da epopeia, como se pode observar no excerto:

Vi por mandado da santa \& geral inquisição estes dez Cantos dos Lusiadas de Luis de Camões, dos valerosos feitos em armas que os Portugueses fizerão em Asia \& Europa, e não achey nelles cousa algủa escandalosa nem contrária â fe \& bõs custumes, somente me pareceo que era necessario aduertir os Lectores que o Autor pera encarecer a difficuldade da nauegação \& entrada dos Portugueses na India, usa de hủa fição dos Deoses dos Gentios. E ainda que sancto Augustinho nas suas Retractações se retracte de ter chamado nos liuros que compos de Ordine, aas Musas Deosas. Toda via como isto he Poesia \& fingimento, \& o Autor como poeta, não pretende mais que ornar o estilo Poetico não tiuemos por inconueniente yr esta fabula dos Deoses na obra, conhecendoa por tal, \& ficando sempre salua a verdade de nossa sancta fe, que todos os Deoses dos Gentios sam Demonios. E por isso me pareceo o liuro digno de se imprimir, \& o Autor mostra nelle muito engenho \& muita erudição nas sciencias humanas. Em fe do qual assiney aqui.

Frei Bertholameu Ferreira. (CAMÕES, 1993, p. 14). 
O valoroso trunfo do poeta, ficcionalizado por Helder Costa e interpretado enquanto hábil arauto, para ser aprovado pela censura se deveu ao fato de estar presente no poema a representação de mundo ptolomaico como a fonte dos conhecimentos concedidos aos portugueses, após sua gloriosa trajetória no Oriente. Vale ressaltar que o modelo de universo geocêntrico, proposto por Ptolomeu, embasava-se na ideia de que a Terra era o centro de tudo e que, se navios fossem em direção ao horizonte, cairiam em um abismo sem fim, associando, assim, a filosofia teocêntrica dominante na época a esse sistema ptolomaico.

Porém, tal modo de compreensão do universo se revelou falho pelas expedições ultramarinas portuguesas, visto que, ao se lançarem ao mar, constataram, por meio de suas próprias experiências, que a Terra não era quadrada e que havia outros mundos a serem alcançados e descobertos. Nesse sentido, o poema Os Lusíadas descreve as conquistas portuguesas durante as investidas marítimas, que, por si só, se configuravam como negação do sistema proposto por Ptolomeu, visto que, caso esse sistema fosse válido, inevitavelmente os portugueses teriam falhado em seu intento de conquistar novos mundos.

A epopeia celebra a índole gloriosa portuguesa de desbravar novos mundos por vias marítimas, o que era prova irrefutável do sistema heliocêntrico ${ }^{75}$, proposto por Copérnico. Portanto, embora CHF sugerisse no episódio da Ilha dos Amores uma visão geocêntrica, essa seria facilmente desmentida ou compreendida como metáfora, quando se considerasse a epopeia como um todo, cujo mote é a confirmação do heliocentrismo.

Conforme ilustra CHF, a autorização de publicação de sua obra se deve ao fato de que "Os Censores usam palas nos olhos, como burros... Basta cedermos um pouco no que eles pensam, deixam passar o mais importante" (COSTA, 1982, p. 94). A cena termina com a sugestão de que a censura inquisitorial preocupou-se tanto com o paganismo da Ilha dos Amores, que não se deu conta da ideologia a partir da qual a obra se consolidava: de exaltação às navegações ultramarinas, cuja essência contradizia a ordem até então estabelecida.

\subsection{Cena V - Ato II - A Nova Ordem}

A última cena da peça é ambientada na Corte do Cardeal D. Henrique, indicando que já se passaram alguns anos desde a cena anterior, em que $\mathrm{CH}$ recebeu a autorização para publicar $O s$ Lusíadas, em 1572. Como sugere a fala da personagem do Conselheiro, a cena se passa

\footnotetext{
${ }^{75}$ Acreditava-se que o Sol era o centro de tudo e que os demais planetas giravam em torno dele, sendo por isso a Terra redonda. Tal modo de pensamento permitiria que, ao navegar rumo ao horizonte, o homem fosse capaz de circundar o mundo.
} 
provavelmente após 1578, quando D. Sebastião desapareceu em batalha, sem deixar filhos ou esposa, sendo por isso necessário que se apagasse “(...) a mancha da tragédia de Alcacer-kibir (...)” (COSTA, 1982, p. 95).

Vale aqui retomar o episódio histórico que levou o Inquisidor-mor a ocupar o trono. O Cardeal D. Henrique, tio-avô do jovem rei desaparecido na batalha, era o parente mais próximo, sendo, por isso, convocado a assumir uma vez mais ${ }^{76}$ o trono português. Abdicando do posto clerical de Inquisidor mor, D. Henrique almejou procurar uma noiva e com ela dar continuidade à dinastia. Porém, o papa Gregório XIII, ligado à família Habsburgo, que pretendia alcançar o trono lusitano, não liberou o Cardeal de seus votos, somando-se a esse empecilho a idade avançada que contava o clérigo.

Embora D. Henrique tenha entrado para a História como uma figura de resistência à União das Coroas Ibéricas, que ocorreria após sua morte, em 1580, quando Filipe de Espanha se tornaria rei, na peça de Helder Costa, a personagem que representa o Cardeal é apresentada de maneira decrépita, feito um velho caduco, que não tem condições de governar Portugal, como demonstra a rubrica que abre a cena “(...) um quadro grotesco, em que se vê um velho Cardeal a mamar numa mulher com umas enormes mamas de papelão. À sua volta, padres e conselheiros”. (COSTA, 1982, p. 95).

Nota-se, desse modo, a fraqueza dos reis, representada na peça de maneira progressiva, primeiro com D. João III, um rei carola e profundamente acomodado com a complexa situação que o país vivia, e, posteriormente, com o jovem e manipulável rei D. Sebastião, que, tal qual um boneco, foi governado pela influência dos irmãos Câmara, consolidando-se como uma decepção em relação ao que dele se esperava para que Portugal voltasse à posição de destaque antes atingida e, finalmente, na figura de D. Henrique, um velho inapto na governança da Nação, pois já não dominava suas faculdades mentais, visto que se comportava como uma criança. Tanto as personagens de D. Sebastião quanto a do Cardeal não têm sequer uma fala na peça, sendo possível depreender que esse silêncio se deve à irrelevância que ambos tiveram na História de Portugal, segundo a cosmovisão de Helder Costa.

Embora a maioria dos historiadores concorde que D. Sebastião não reunia as características de um bom administrador, o Cardeal D. Henrique é, de modo geral, apresentado nos livros de História como um homem que lutou até o limite de suas forças para evitar que Portugal perdesse sua autonomia política.

\footnotetext{
${ }^{76}$ O clérigo já havia governado Portugal em conjunto com a cunhada, D. Catarina de Aragão, entre 1562 e 1568 , até que o jovem infante D. Sebastião pudesse assumir o trono.
} 
A cena não apresenta qualquer fala do Cardeal D. Henrique, uma vez que apenas seus conselheiros se expressam para contextualizar a situação do país, inclusive incitando a necessidade de proclamar-se o Cardeal como monarca. Caso isso não ocorresse, o trono cairia nas mãos de Filipe II de Espanha, resultando na inevitável e temida União das Coroas Ibéricas. Tamanho é o temor pela perda da independência, que se menciona a possibilidade de uma guerra semelhante à ocorrida em 1383, em menção direta à Revolta que colocou o mestre de Avis no poder:

BISPO - Cardeal D. Henrique, não deixemos que a indignação da populaça alastre. CONSELHEIRO 3 - Recordai-vos, Alteza, que uma tragédia superior nos pode acontecer. Recordai-vos da revolta de $1383 \ldots$ (...)

CONSELHEIRO 2 - O Rei de Espanha tem direito à sucessão ao trono de Portugal! (COSTA, 1982, p. 95).

A respeito da comparação entre a Revolução de Avis e a Conquista do reino por parte de Filipe II, José Hermano Saraiva aponta "A vitória do Mestre de Avis foi conseguida contra uma Castela enfraquecida por um longo período de guerras civis; a derrota do prior do Crato foi imposta pela Espanha já unificada e numa fase de opulência económica.” (1993, p. 177).

Embora na peça de Helder Costa a personagem que representa o Cardeal D. Henrique seja caricatural, a figura histórica do inquisidor mor teria concentrado “(...) todos os seus esforços no sentido de conseguir uma solução pacífica, por via jurídica, que impedisse o recurso da violência" (SARAIVA, 1993, p. 176) no que tangia à sucessão do trono português. Em sua vida eclesiástica, o cardeal teria sido ativo quanto à instituição de um Conselho Geral do Santo Ofício em Portugal, estabelecendo regimentos normatizadores, tais como a publicação do primeiro Index de livros proibidos, além da organização de tribunais distritais, que deram à Inquisição portuguesa seu formato mais clássico. Assim, a representação da personagem pelo viés da incapacidade do clérigo configura-se bastante sui generis no dramaturgo contemporâneo, visto que, para a História, ele teria sido o monarca que teria adiado, ainda que por pouco tempo, a temida União das Coroas Ibéricas.

Com a morte de D. Henrique, ocorrida em 1580, a Coroa Portuguesa deveria ter por sucessor algum dos netos de D. Manuel I: Filipe II de Espanha, filho de D. Isabel; D. António, prior de Crato, filho bastardo do Infante D. Luís e uma cristã-nova, cuja legitimidade nunca fora reconhecida pelo Cardeal: D. Catarina, duquesa de Bragança, filha de D. Duarte. Dentre os primeiros, houve um conflito, no qual Filipe II impôs sua vitória por meio da força, apoiado por D. Catarina, que o favorecia na disputa.

O pavor da temida tutela espanhola está presente em toda a cena, intitulada A Nova Ordem. No diálogo final da peça, o domínio espanhol é tratado como um fato já consumado. A personagem 
de Chiado aparece cantarolando alguns versos contra as injustiças praticadas no reino, conforme revela o excerto:

CHIADO - Vê aqueles que devem à pobreza

Amor divino, e ao povo caridade,

Amam somente mandos e riqueza,

Simulando justiça e integridade.

BISPO - Chiado, quereis insultar a Santa Madre Igreja?

CHIADO - Não... Não, só falo de injustiças. Para passar o tempo...

BISPO - Não convém andar por aí, pelas ruas, a gritar essas palavras...Isso não é do agrado de El-Rei D. Filipe... Sabeis bem que qualquer coisa pode acender os ânimos desta populaça.

CHIADO - Eu sei. E também sei que Portugal caíu do mais alto ponto para o abismo mais profundo.

BISPO - Portugal, caíu num abismo? Que dizes, devasso! Portugal continua forte, valoroso, digno... Portugal salvou-se das forças do mal... (...)

CHIADO - Lope de Veja! Ah! Ah! Ah! Esta foi a imagem criada por vós, da minha Pátria... Uma imagem de fanfarronice e mentira...

Felizmente que a morte poupou Camões, Góis, Duarte Pacheco e outros de assistir a este ultraje. Bispo! Só vale a pena lutar pela verdade, lá dizia o velho Garcia da Orta, que Deus tenha em descanso.

(COSTA, 1982, p. 96-7).

Chiado evidencia em sua fala que Portugal caiu em um abismo, abandonando no passado a imagem gloriosa para tornar-se uma mentira, sob o domínio espanhol. Segundo a personagem, a morte de homens ilustres como $\mathrm{CH}$, Góis $^{77}$ e Duarte Pacheco ${ }^{78}$ teria lhes livrado de assistir à triste derrocada de uma Pátria pela qual, cada um a seu modo, teria lutado para eternizar. Porém, para Chiado, "Só vale a pena lutar pela verdade" (COSTA, 1982, p. 97) e a Pátria se tornara uma farsa, transformando-se, assim, em embuste que não justificaria a luta.

A Nova Ordem, referida no título da cena, remete aos novos rumos que o país tomou nas mãos do governante espanhol, que, embora significassem uma nova era na História Portuguesa, também punham fim à derrocada crescente que começara reinos antes. Segundo A. H. de Oliveira Marques (1978), o domínio espanhol esteve limitado em grande medida à manutenção da administração externa comum a ambos os países ibéricos, enquanto que a administração interna esteve a cargo dos portugueses, que continuaram a adotar políticas econômicas pouco progressistas, que, apenas anos mais tarde, entre 1582 e 1590, implementaram efetivas melhorias nos sistemas judiciário e financeiro, inspiradas nos modelos espanhóis de funcionalismo.

\footnotetext{
${ }^{77}$ Damião de Góis - humanista que fora discípulo de Erasmo de Roterdã.

${ }^{78}$ Cosmógrafo, navegador e integrante da delegação portuguesa que negociou o Tratado de Tordesilhas, a partir do qual o mundo, até então conhecido, foi dividido entre Portugal e Espanha.
} 
A visão pessimista da personagem de Chiado perpassa também o modo como Diogo do Couto se refere à perseguição a Garcia da Orta, cujos restos mortais, como já apontado, foram exumados para tomar parte em um auto de fé. A representação do momento da exumação tem, por pano de fundo, no texto teatral, alguns versos do epílogo d'Os Lusíadas, transcritos a seguir:

\author{
No-mais, Musa, no-mais, que a lira tenho \\ Destemperada e a voz enrouquecida, \\ E não do canto, mas de ver que venho \\ Cantar a gente surda e endurecida. \\ O favor com que mais se acende o engenho, \\ Não no dá a pátria, não, que está metida \\ No gesto da cobiça e da rudeza \\ Duma austera, apagada e vil tristeza.
}

(COSTA, 1982, p. 97- ref. ao Canto X, 145 d'Os Lusíadas).

Os versos indicam o descompasso entre a grandeza do que é cantado, as glórias da Pátria portuguesa e o despreparo dos ouvintes, sendo esse último atribuído pelo eu-lírico à cobiça e à rudeza, que passaram a caracterizar os lusitanos.

A Nova Ordem consistia não somente no domínio da Espanha sobre Portugal, mas na perenidade da glória da Pátria. Essa essência deveria ser mantida imaculada, eternizada no poema de Camões, permanecendo viva independente da ação do tempo e dos homens, visto ser a verdadeira inspiração que Garcia da Orta incita ao poeta, quando esse se mostra indignado com a implantação da Inquisição na Índia:

GARCIA DA ORTA - Não, Luís Vaz!

Acusa as injustiças e prepotências dos governantes, denuncia a Igreja mistificadora, ataca a barbárie da Inquisição, combate a ignorância e o medo, mas ama tua Pátria. Nós mostramos novos Mundos ao Mundo, e muitos de nós, os que acreditam na mudança das coisas, querem o amor e a paz, entre todas as raças.

É uma luta que dura há séculos.

Precisamos de poetas que saibam cantar... (COSTA, 1982, p. 84).

$\mathrm{O}$ vate soube cantar a quintessência inalterada do amor à Pátria. No entanto, isso não significou que estivesse entorpecido pela bruma espessa da cegueira idealizadora, mas que, segundo a visão apresentada por Helder Costa, o bardo tivesse, por meio de sua experiência prática, optado por usar seu engenho e arte na eternização do que acreditava ser um valor mais alto para caracterizar Portugal.

A proposta teatral de Bertold Brecht tem por cerne a apreensão do homem com base nos processos que o compõem, além do caráter didático, que visa a esclarecer o público a respeito da 
sociedade e da necessidade de transformá-la, incitando-o à ação transformadora, que viria da consciência do espectador como agente transformador da História. De acordo com Anatol Rosenfeld, o teatro épico brechtiano busca “elevar a emoção ao raciocínio. (...) a 'desmistificação', a revelação de que as desgraças do homem não são eternas e sim históricas, podendo por isso ser superadas." (2006, p. 148-52).

Sob a óptica do teatro épico retomado por Brecht, Helder Costa propõe a releitura do período das grandes navegações, nas quais Portugal exerceu um papel decisivo e, por isso, é considerado por muitos como o auge inquestionável desse reino. Com tal intento, o encenador elege dois textos de partida, Os Lusíadas, de Luís Vaz de Camões, e O Soldado Prático, de Diogo do Couto, que apresentam visões divergentes a respeito das navegações portuguesas, resultando no embate entre vozes de autores distintos, que se contrariam. Porém, a própria visão apresentada por Helder Costa não se limita a reproduzir ambos os textos base, mas busca construir uma terceira perspectiva, que, por estar deslocada no tempo futuro, amplia o atrito entre as visões acerca das expedições ultramarinas de Luís de Camões e de Diogo do Couto, resultando na desmistificação do passado.

Novo choque é percebido entre Luís de Camões, autor d'Os Lusíadas, e a personagem criada por Helder Costa. O primeiro, $\mathrm{CH}$, inserido em seu tempo, esteve imbuído de profundo nacionalismo, que o impedia de ver além de seu tempo, em oposição ao segundo, CHF, que dispõe de apurada visão crítica acerca da realidade vigente, sendo assim capaz de antever os resultados das ações malogradas do presente no futuro, estando por isso afastado de seu próprio tempo, o que lhe permite enxergar com distanciamento.

É por meio dessa divergência que ocorre a própria reestruturação da experiência camoniana, que na personagem histórica estaria limitada ao século em que viveu, enquanto na peça apresenta a própria visão de Helder Costa acerca do que critica. É como se o encenador português tentasse se passar por $\mathrm{CH}$, porém revestindo-o com a capa da contemporaneidade.

Desta forma, é possível compreender que Os Lusíadas, recontado aos moldes do presente como tentativa de reler criticamente o passado, apresenta a maturidade advinda da passagem do tempo. Desconsiderando o anacronismo em que se fundamenta o texto teatral, a experiência prática adquirida com a viagem de CHF na expedição de Vasco da Gama, cinquenta e seis anos antes de o vate, de fato, ter embarcado para as Índias, permite ao poeta ter consciência de seu tempo, de modo a poder relê-lo criticamente.

O emprego de recursos intertextuais, tais como a paródia, a estilização e a paráfrase, tem por função evidenciar os paradigmas, de modo a observá-los sob nova óptica, além de construir com riqueza de detalhes as experiências que fundamentam a visão crítica de CHF acerca de seu tempo. 
O objetivo da estilização, em sentido de superação dos paradigmas, nutre a ousada metaficção historiográfica, que preenche as "lacunas" históricas de $\mathrm{CH}$, contextualizando o bardo dentro do período em questão e permitindo que haja forte verossimilhança interna a sustentar o texto da peça teatral, cujo objetivo central está em debruçar-se sobre o passado, de modo a repensá-lo como produto da História, e não como mote nostálgico que bem caracteriza o povo português em sua psique estruturalmente saudosa. 


\section{DESENLACE DA JORNADA}

PERGUNTAS DE UM TRABALHADOR QUE LE

Quem construiu a Tebas de sete portas? Nos livros estão nomes de reis. Arrastaram eles os blocos de pedra?

E a Babilónia várias vezes destruídaQuem a reconstruiu tantas vezes? Em que casas

Da Lima dourada moravam os construtores? Para ondem foram os pedreiros, na noite em que a Muralha da China ficou pronta?

A grande Roma está cheia de arcos do triunfo. Quem os ergueu? Sobre quem

Triunfaram os Césares? A decantada Bizâncio Tinha somente palácios para seus habitantes? Mesmo na lendária Atlântida,

Os que se afogavam gritaram por seus escravos. Na noite em que o mar a tragou.

O jovem Alexandre conquistou a Índia. Sozinho?

César bateu os gauleses. Não levava sequer um cozinheiro? Filipe da Espanha chorou, quando sua Armada

Naufragou. Ninguém mais chorou? Frederico II venceu a Guerra dos Sete Anos. Quem venceu além dele?

Cada página uma vitória. Quem cozinhava o banquete? A cada dez anos um grande homem.

Quem pagava a conta?

Tantas histórias Tantas questões.

(BRECHT, 2000)

A análise interpretativa do texto teatral de Helder Costa, A viagem - Camões - Poeta prático, apresentada nos dois capítulos anteriores pressupõe que, embora se trate de um texto ficcional, a História Portuguesa ocupa papel fulcral na compreensão da peça teatral. Essa afirmação encontra justificativa desde o primeiro capítulo desse trabalho, "Enredo e Personagens", quando se traçou uma breve História de Portugal como reino independente, até a Revolução dos Cravos, em 1974. Porém, naquele ponto do trabalho, o objetivo era criar um cabedal de referências históricas acerca do período compreendido desde o nascimento de Portugal como reino independente até a União das Coroas Ibéricas.

Esse capítulo tem como primeiro objetivo tratar das fronteiras entre a História e a Ficção, pois parece residir aí o cerne que permite a aproximação da discussão mais prática a respeito da 
peça A Viagem - Camões - Poeta prático enquanto releitura crítica do passado português. Na sequência, serão pontuados alguns aspectos que estão relacionados ao drama histórico, gênero esse que fincou profundas raízes na conturbada pós-modernidade.

O texto teatral, objeto de análise dessa dissertação, exemplifica com maestria o diálogo intertextual entre dois campos diversos de conhecimento. Ficcionalizam-se episódios históricos situados desde o período das grandes navegações até a decadência portuguesa e a consequente perda de autonomia política com o domínio espanhol, a partir da proposta de releitura do passado português, aos moldes de Helder Costa, o qual pretende que o espectador repense o presente, na contemporaneidade, por meio da "Lição da História".

Porém, antes de examinar o objetivo de Helder Costa, faz-se premente debruçar-se a respeito da distinção entre História e Literatura, posto que desse atrito surge o texto teatral A Viagem - Camões - Poeta prático. Em função das diferenças aparentemente inconciliáveis entre os dois campos de conhecimento, considerando que a História é tida como ciência que goza de larga credibilidade por lidar com fatos do passado e que a Literatura é compreendida como o espaço do ficcional, do inventivo, a junção dessas áreas e seu consequente apagamento de "fronteiras" instiga à reflexão.

O poema de Bertold Brecht, intitulado Perguntas de um trabalhador que lê (2000), epígrafe que abre o capítulo, evidencia a inconteste predileção que os registros históricos apresentam na confecção de honra e glória a reis e governantes, em detrimento de outras personagens históricas essenciais, que, por suas posições de desprestígio na sociedade, foram legadas ao ostracismo. O dramaturgo alemão elabora uma série de perguntas a partir de fatos largamente conhecidos na História, incitando o questionamento acerca da fidedignidade dos registros do passado.

A frase popular de que a História é escrita pelos vencedores remete à pesada carga ideológica de que os relatos históricos se encontram imbuídos. Tendo em vista o poema de Bertold Brecht e a sentença popular anteriormente mencionada, cabe considerar em que medida a História é apenas a História de grupos privilegiados por suas posições sociais.

O livro de Keith Jenkins, A História Repensada (2004), discute em suas primeiras páginas a problemática definição do que é História e de como se dá sua escrita. O autor busca diferenciar a História do Passado, ao afirmar que:

(...) a história constitui um dentre uma série de discursos a respeito do mundo. Embora esses discursos não criem o mundo (aquela coisa física na qual aparentemente vivemos), eles se apropriam do mundo e lhe dão todos os significados que têm. O pedacinho de mundo que é o objeto 'pretendido' de investigação da história é o passado. A história como discurso está, portanto, numa categoria diferente daquela sobre a qual discursa. Ou seja, passado e história são coisas diferentes. (...) O passado e a história existem livres um do outro; estão muito distantes entre si no tempo e no espaço. (p. 23-4). 
O historiador britânico discute a constante necessidade de separar Passado e História, levando em conta que o primeiro, enquanto discurso histórico, é produzido pelos historiadores, sendo, portanto, um constructo linguístico intertextual. Nas palavras do autor:

(...) a história, embora seja um discurso sobre o passado, está numa categoria diferente dele. (...) Tendemos a perder de vista o fato de que realmente exista esta distinção entre a história - entendida como o que foi escrito/registrado sobre o passado - e o próprio passado, pois a palavra "história" cobre ambas. Portanto, seria preferível sempre marcar essa diferença usando o termo "o passado" para tudo que se passou antes em todos os lugares e a palavra "historiografia" para a história (...) (JENKINS, 2004, p. 24).

Em outras palavras, as informações históricas que se conhecem são, na verdade, compêndios de interpretações vastamente difundidas, que acabam por se tornar base para "novos" discursos históricos interpretativos. Logo, a historiografia, no sentido em que Keith Jenkins (2004) propõe, deve ser considerada como uma construção linguística de inter-relações entre discursos largamente difundidos e as "novidades" discursivas.

Segundo Jenkins (2004), as noções de Passado e História podem ser melhor compreendidas em sua especificidade quando se consideram grupos, povos ou pessoas que foram "escondidos na História", ou seja, omitidos dos discursos da historiografia dominante, mas que não deixaram de existir no passado, conforme a epígrafe desse capítulo sugere. Atualmente, vive-se uma torrente de propostas historiográficas de inclusão de novos discursos, tais como o do feminino, o do negro, entre tantos outros que foram legados, durante muito tempo, ao "esquecimento histórico".

Nesse ponto, cabe ressaltar que, embora a História seja, em grande medida, construção discursiva, seja de um grupo social, do próprio indivíduo que registra o passado, ou mesmo da junção de ambos, não se deve reduzi-la à mera apuração subjetiva de acontecimentos passados e interpretações aleatórias, visto que, para a construção do discurso histórico, há rigorosos métodos de verificação de dados e de compromisso com a "verdade", ainda que não seja possível descartar os aspectos narrativos e interpretativos intrínsecos ao discurso histórico.

A esse respeito, Linda Hutcheon, em A poética do Pós-modernismo, ao discutir o conceito de pós-modernidade, assegura que o passado só é acessível por meio de sua textualidade, ou seja:

(...) não podemos conhecer o passado, a não ser por meio de seus textos: seus documentos, suas evidências, até seus relatos de testemunhas oculares são textos. Até mesmo as instituições do passado, suas estruturas e práticas sociais, podem ser 
consideradas, em certo sentido, como textos sociais. E os romances pós-modernos nos dizem algo sobre esse fato e sobre suas conseqüências. (1991, p. 34).

Em vista da não materialidade intrínseca do passado, este só se torna acessível por meio da composição escrita de um registro, o que implica tanto na impossibilidade de haver um único relato que contemple o todo dos fatos passados, quanto na inevitável escolha, ainda que inconscientemente subjetiva, de quais acontecimentos relatar.

Corroborando esse ponto de vista, Jenkins afirma que:

(...) nenhum historiador consegue abarcar e assim recuperar a totalidade dos acontecimentos passados, porque o 'conteúdo' desses acontecimentos é praticamente ilimitado. Não é possível relatar mais que uma fração do que já ocorreu, e o relato de um historiador nunca corresponde exatamente ao passado: o simples volume desse último inviabiliza a história total. A maior parte das informações sobre o passado nunca foi registrada, e a maior parte do que permaneceu é fugaz. (...) nenhum relato consegue recuperar o passado tal qual ele era, porque o passado são acontecimentos, situações etc., e não um relato. Já que o passado passou, relatos só poderão ser confrontados com outros relatos, nunca com o passado. (2004, p. 31-2).

Partindo do pressuposto pós-moderno, Hayden White aponta que:

(...) o passado é o que decidimos lembrar dele; o passado não tem existência fora da consciência que temos dele. Escolhemos o nosso passado da mesma forma que escolhemos o nosso futuro. Portanto, o passado histórico, como os nossos diversos passados pessoais, é no melhor dos casos um mito que justifica o nosso jogo num futuro específico e, no pior, uma mentira, uma racionalização retrospectiva daquilo que, de fato, nos tornamos mediante as nossas escolhas. (1994, p. 51).

Assim, pode-se depreender que, embora a História ou, mais adequadamente nomeada, a Historiografia carregue o peso de tratar do "verídico passado", não é possível saber em que medida o registro não é apenas parte desse mesmo passado. Nesse sentido, a separação inicial e inflexível de que História e Literatura se diferem pelo motivo de a primeira tratar da verdade e a segunda do verossímil cai por terra, visto que, de certa maneira, o que se registra como "verdade" é apenas uma das muitas possíveis intepretações de um discurso subjetivo. Nas palavras de Jenkins:

(...) a maneira com a qual o historiador tenta entender o passado - é crucial para determinar as possibilidades do que a história é e pode ser, até porque a pretensão da história ao conhecimento (em vez de considerar-se simples fé ou alegação) é o que a torna o discurso que é (com isso, quero dizer que os historiadores não 
costumam considerar-se ficcionistas, embora possam sê-lo sem se darem conta). (2004, p. 29).

Hayden White (1994) tece argutas observações a respeito da representatividade histórica do discurso, conforme se pode notar no excerto a seguir:

Os teóricos da historiografia geralmente concordam em que todas as narrativas históricas contêm um elemento de interpretação irredutível e inexpungível. O historiador deve interpretar a sua matéria a fim de construir um padrão que irá produzir as imagens em que deve refletir-se a forma do processo histórico. E isto porque o registro histórico é ao mesmo tempo compacto demais e difuso demais. De um lado, sempre existem mais fatos registrados do que o historiador pode talvez incluir na sua representação narrativa de um dado segmento do processo histórico. E, assim, o historiador deve "interpretar" os dados, excluindo de seu relato certos fatos que sejam irrelevantes ao seu propósito narrativo. De outro lado, no empenho de reconstruir "o que aconteceu" num dado período da história, o historiador deve inevitavelmente incluir em sua narrativa um relato de algum acontecimento ou conjunto de acontecimentos que carecem dos fatos que poderiam permitir a explicação plausível de sua ocorrência. E isto significa que o historiador precisa "interpretar" o seu material, preenchendo as lacunas das informações a partir de inferências ou de especulações. Uma narrativa histórica é, assim, forçosamente uma mistura de eventos explicados adequada e inadequadamente, uma congérie de fatos estabelecidos e inferidos, e ao mesmo tempo uma representação que é uma interpretação e uma interpretação que é tomada por uma explicação de todo o processo refletido na narrativa." (WHITE, 1994, p. 65).

Ainda acerca do mesmo assunto, o autor infere que se “(...) visto apenas como artefatos verbais, as histórias e os romances são indistinguíveis uns dos outros. Não podemos distinguir com facilidade entre eles, em bases formais, a menos que os abordemos com pré-concepções específicas sobre os tipos de verdade de que cada um supostamente se ocupa" (WHITE, 1994, p. 138).

O historiador francês Georges Duby demonstra acurada percepção de que a História e a Literatura se diferem fundamentalmente:

(...) na medida em que a ficção histórica está forçosamente ligada a algo que foi verdadeiramente vivido, mas, no fundo, a forma de abordagem não é muito diferente. O historiador conta uma história, uma história que ele forja recorrendo a um certo número de informações concretas (...) tendo plena consciência de que jamais chegaremos a uma verdade objectiva. (1989, p. 11).

Sugere-se, então, que a distinção entre os campos literário e histórico se formule com base no modo como cada um deles se compromete com essas interpretações. À História cabe o registro, ainda que subjetivo, do passado, estabelecendo com ele uma relação de profundo "respeito" e "compromisso", por torná-lo acessível como memória da humanidade, ao passo que a Literatura 
não tem qualquer obrigatoriedade com esta "verdade histórica", mas sim com a verossimilhança do que é narrado. Em suma, a História narra o que possivelmente ocorreu, enquanto a Literatura, o que poderia ter acontecido. A esse respeito, Aristóteles (1981) ${ }^{79}$ diferencia o fazer do historiador e o do poeta, afirmando que ambos não se diferem pelo formato em que escrevem, prosa ou verso, mas porque um escreve o que aconteceu, e o outro, o que poderia ter acontecido.

Neste sentido, A Viagem - Camões - Poeta prático pode ser compreendida como pedra de contato entre a Literatura e a História, por meio da qual o dramaturgo português busca reler o período das grandes navegações do poderoso Império Lusitano dos séculos XIV e XVI. Porém, antes de discutir a releitura proposta, cabe sinalizar algumas das mudanças ocorridas, principalmente no que tange à História, de modo a possibilitar a aproximação entre esse campo de conhecimento e os demais.

Antes da década de 1970, a historiografia se caracterizava, predominantemente, pela narrativa política e econômica do passado, nomeada como vertente positivista, até então dominante no que concernia aos estudos dessa área de conhecimento. A terceira geração da Escola Francesa de Annales, representada por estudiosos como Jacques Le Goff e Pierre Nora, trouxe a público uma nova proposta de estudo da História, que se diferenciava essencialmente por propor a interação com outras áreas de conhecimento, tais como a Antropologia, a Sociologia e a Geografia, almejando à composição da História Total. Ainda que já se tenha discutido acerca da inviabilidade do projeto devido à abrangência do assunto e à própria "fragilidade" de se conceber a História como um relato geral, portanto completo, esta noção ampliou os horizontes do fazer histórico. Em última análise, a partir da proposta da Nova História, o conceito de construção identitária, advindo de uma separação substancial entre as áreas de conhecimento, flexibilizou-se, de modo a permitir que houvesse o diálogo em termos efetivos. Dessa forma, um mesmo evento poderia ser observado sob distintas perspectivas, agregando-se assim inúmeras formas de interpretá-lo. A este respeito, Jacques Le Goff atribui à Nova História o caráter de lutar contra a História Política, que, segundo o teórico:

Essa história política que é, por um lado, uma história - narrativa e, por outro, uma história de acontecimentos, uma história factual, teatro de aparência que mascara o verdadeiro jogo da História, que se desenrola nos bastidores e nas estruturas ocultas em que é preciso ir a detectá-lo, analisá-lo, explicá-lo. (1988, p. 31).

A revista Annales configurou-se como um marco divisor entre uma História, em sentido singular, por isso limitada à sua própria esfera de conhecimento, e outra que, segundo Rogério Forastieri da Silva (1999), não foi nova por ser original, posto que outros historiadores anteriores já

\footnotetext{
${ }^{79}$ Ano do exemplar consultado.
} 
demonstravam tal "preocupação historicizante", mas sim por propor o olhar plural da História, ou, talvez deva-se dizer, das Histórias.

Foi a partir dessa concepção historiográfica, nomeada Nova História, que se ampliou a restrita definição de wie es eigentlich gewesen $^{80}$, a qual, permeada por forte religiosidade, julgava que o registro de um feito ou de dados de uma personalidade garantiam em si sua essência, sem que houvesse qualquer subjetividade do historiador nos documentos.

A perspectiva da Nova História permitiu que se repensasse inclusive a função da História. A esse respeito, Georges Duby observa que:

(...) A história é, antes de mais, um divertimento: o historiador sempre escreveu por prazer e para dar prazer aos outros. Mas também é verdade que a história sempre desempenhou uma função ideológica, que foi variando ao longo dos tempos (...) essa função consistia numa interpretação moral dos factos: narrando os acontecimentos do passado, pretendia se mostrar aos homens como é que Deus queria que eles agissem. Esta função de pedagogia moral manteve-se por muito tempo (...) algum tempo depois de (...) os Estados europeus se reconstituíram, os historiadores puseram-se ao serviço dos Estados, ao serviço do Príncipe, e essa moral transformou-se numa moral política. (...) Quando se constitui a unidade francesa, sob a autoridade monárquica, escreve-se a história da França. E é evidente que, no grande momento da história positiva, estava no apogeu um sentimento nacional com uma forte coloração chauvinista. (...) O importante parece ser, actualmente, escrever uma vastíssima história de todas as civilizações do mundo, nas suas relações recíprocas, enquanto, por outro lado e por um movimento inverso, assistimos ao reaparecimento de uma história muito local (...) É absolutamente necessário que o historiador colabore na tarefa essencial que consiste em manter vivo na nossa sociedade o espírito crítico. (...) toda informação é subjectiva, que é necessário recebê-la como tal e, por conseguinte, criticá-la (1989, p. 14-9).

A atitude crítica diante de concepções até então plenamente estabelecidas torna-se evidente. Um exemplo dessa postura reflexiva encontra-se nos estudos bakhtinianos a respeito da característica eminentemente dialógica de todo discurso, o qual estabelece diálogo com a rede de discursos que o cercam, fazendo emergir dissonâncias nas vozes do autor e de suas personagens, que passam a ser independentes de seu criador.

A pós-modernidade caracteriza-se, segundo Linda Hutcheon, por seu aspecto fundamentalmente contraditório, visto que busca situar num mesmo plano elementos que se contrapõem. Nas palavras da autora, as oposições ocorrem a partir da "presença do passado", que:

Não é um retorno nostálgico; é uma reavaliação crítica, um diálogo irônico com o passado da arte e da sociedade, (...) O passado cuja presença defendemos não é

80 "Como era na realidade", cunhado por Leopold Von Ranke, de acordo com Hughes (1967). 
uma idade de ouro que deva ser recuperada. (...) Suas formas estéticas e suas formações sociais são problematizadas pela reflexão crítica. (...) é sempre uma reelaboração crítica, nunca um "retorno" nostálgico. É aí que está o papel predominante da ironia no pós-modernismo. (1991, p. 20-1).

Infere-se que a pós-modernidade é caracterizada pela contrariedade das ordens previamente estabelecidas, o que, segundo François Lyotard (1989), reflete a descrença em metanarrativas, que seriam "estórias" de proporções míticas, amplas o suficiente para estabelecer relações entre diferentes campos de conhecimento, atribuindo, em última análise, um sentido unificado para a sociedade. No entanto, no contexto pós-moderno, não há mais centros únicos, porém pequenos centros que se deslocam, inclusive para ceder lugar ao periférico. Em outras palavras, a pósmodernidade seria o espaço da "morte dos centros" (JENKINS, 2004, p. 28), caracterizada pela incredulidade generalizada e pela crença de que tudo é temporário, posto que as metanarrativas não são mais reais ou promissoras. Evidenciam-se, assim, "fendas" nas antigas certezas, dentre as quais a do registro objetivo da História. Debruça-se sobre o pretérito para repensá-lo, não mais de forma nostálgica ou saudosista, porém crítica, o que Helder Costa se propõe a fazer em A Viagem Camões - Poeta prático.

Esse é o processo nomeado por Linda Hutcheon (1991) como metaficção historiográfica, ou seja, o preenchimento das lacunas que foram deixadas pelos discursos da História, os quais, sabe-se, são, necessariamente, ideológicos e subjetivos. Tomemos o conceito cunhado por Hutcheon expresso a partir de suas próprias palavras:

A metaficção historiográfica refuta os métodos naturais, ou de senso comum, para distinguir entre o fato histórico e a ficção. Ela recusa a visão de que apenas a história tem uma pretensão de verdade, por meio do questionamento da base dessa pretensão na historiografia e por meio da afirmação de que tanto a historia como a ficção são discursos, constructos humanos, sistemas de significação, e é a partir dessa identidade que as duas obtêm sua principal pretensão à verdade. Esse tipo de ficção pós-moderna também recusa a regulação do passado extratextual ao domínio da historiografia em nome da autonomia da arte. (...) O referente "real" (...) já existiu, mas hoje só nos é acessível em forma textualizada: documentos, relatos de testemunhas oculares, arquivos. O passado é "arqueologizado" (...) mas sempre se reconhece seu repositório de materiais disponíveis como sendo textualizado. (HUTCHEON, Apud CORRADIN, 2013, p. 203).

Esse procedimento, embora pensado primeiramente para o gênero romance, estendeu-se ao teatro. Nesse sentido, Helder Costa apropria-se de uma “(...) autoconsciência teórica sobre a História e a Ficção como criações humanas (metaficção historiográfica)”, que passam “(...) a ser a base para seu repensar e sua reelaboração das formas e dos conteúdos do passado." (HUTCHEON, 
1991, p. 21-2). Não há espaço para verdades históricas absolutas, sendo, por isso, respeitado o sujeito enquanto indivíduo, pois pode contrapor-se ao que é aceito como "verdade".

Linda Hutcheon indica que, para tal intento, as mais poderosas ferramentas sejam a paródia, que neste contexto não é algo necessariamente negativo, mas, ao contrário, configura-se como um "canto paralelo", que busca refletir a respeito de seu paradigma, e a ironia, também utilizada como elemento dessacralizante. Assim, infere-se que a intertextualidade é uma manifestação dessa tendência pós-moderna, embora já existisse há muito tempo.

Trata-se de recontextualizar no presente um modelo paradigmático, atribuindo-lhe novos significados, deformando-o ou mesmo subvertendo-o. Intertextualidade pressupõe a interação entre diferentes tecidos, que, em choque, criam o atrito a respeito do qual Pavis (2008) trata, ao afirmar que a citação implica na retirada de um tecido (texto) de sua origem para, em seguida, inseri-lo em um tecido estranho, de modo que não se tenha nem apenas o texto inicial, paradigma, nem somente o texto em que foi inserido, o intertexto, porém uma terceira esfera, na qual interagem ambos os textos, a formular novos significados. Cria-se uma espécie de colcha de retalhos, composta por diversos textos, que, em atrito, adquirem novos significados, assim como o texto teatral de Helder Costa, que, ao se ressignificar, encontra novos sentidos para seu atual contexto.

Assim, a escolha do período português tido por áureo como referente histórico pressupõe projetar outro olhar; neste caso, desconstruindo o ideário de que, naquele momento da História, Portugal não enfrentava adversidades enquanto Nação. Em outras palavras: A Viagem - Camões Poeta prático lança novo jogo de luzes a respeito dos séculos das grandes navegações lusitanas, com o objetivo de "desconstruir" a imagem de perfeição e suposta felicidade que se enraizou no ideário da cultura portuguesa, de tal modo que, em virtude da derrocada sofrida após a perda da autonomia portuguesa, devido à União das Coroas Ibéricas, o ser português cerrou seus olhos para o presente, caracterizando-se como saudosista, perdido em nostalgias que, na visão de Helder Costa, precisam ser desmistificadas, posto que o passado não mais retornará.

Para tal intento, o dramaturgo português contemporâneo vale-se do discurso intertextual, ora paródico, ora estilizador, ora parafrásico, fazendo uso da metaficção historiográfica, a fim de suprir as lacunas da História e recontá-la a seus moldes.

Maria de Fátima Marinho afirma existirem três modos clássicos de narração: o original, em que a História interessa por si só; o reflexo, dicotomia entre o presente e o passado; e o filosófico, que se debruça sobre a própria História. A autora afirma que "as personagens do passado emergem da sua relatividade histórica, significando também arquétipos do presente". (1999, p. 37). A noção de que é possível debruçar-se sobre o passado e, sob o viés crítico, repensá-lo, retoma a proposta do dramaturgo Helder Costa no texto teatral A viagem - Camões - Poeta prático. 
A cartilha da dramática aristotélica tem por objetivo central a catarse, que consiste na “purgação das paixões (essencialmente terror e piedade) no próprio momento da sua produção, no espectador que se identifica com o herói trágico. (...) Essa purgação, que foi assimilada à identificação e ao prazer estético, está ligada ao trabalho imaginário e à produção da ilusão cênica" (PAVIS, 2008 p. 40). O teatro épico existe desde a Idade Média e se caracteriza por conter momentos épicos, de narração, e não de dramatização. Porém, aos poucos, o teatro passou a desativar a mola dramática e substituí-la por momentos de relato, sendo o dramaturgo alemão Bertold Brecht o responsável por conceituar como teatro épico a prática da diegese $e^{81}$, em detrimento da mimese $e^{82}$. Para tanto, propunha o efeito de estranhamento entre os atores e suas personagens, o público e os atores, e, em última análise, a inserção de elementos tipicamente narrativos, como a representação de cenas soltas, a introdução de narrador, epílogos ou mesmo recursos que acabam por gerar no espectador a não identificação com a personagem ali representada, o que resulta na manutenção da consciência crítica do espectador diante do que lhe é representado.

A principal proposta do dramaturgo e poeta alemão se relaciona diretamente ao fato de ele enxergar o espaço cênico como "local de conscientização", advindo daí o aspecto didático muitas vezes atribuído às suas peças. Para além disso, espera-se que, despertada a criticidade, seja possível ao espectador traçar um paralelo, certo reconhecimento, embora não total, com o que é representado, permitindo que se estabeleça uma ponte entre o que se vê e o que se vive fora do palco. Em outras palavras, o teatro épico brechtiano propõe o deslocamento do olhar do espectador para longe de si, para que, na medida em que esteja a "certa distância", possa enxergar melhor a si mesmo a partir do outro. Logo, o que move essa modalidade teatral é o processo de sair de si, olhar para o outro e retornar para si, enxergando-se de maneira distinta.

A proposta de Helder Costa, embora objetive à releitura crítica do passado português, não se vale do efeito de estranhamento entre público e personagens num primeiro momento. Ao contrário, são colocadas no palco personagens viscerais da cultura portuguesa, dentre as quais talvez uma das mais significativas para o ideário lusitano seja o poeta Luís Vaz de Camões.

No entanto, a personagem histórica, a respeito da qual tão pouco se sabe, é substituída por outra personagem, igual em aparência, mas que nasce da subjetividade e da mundividência de seu criador. Caracteriza-se, assim, no texto teatral de Helder Costa, uma personagem visceralmente crítica, visto ser capaz de avaliar, pela reflexão, o mundo que a cerca. Neste ponto, afasta-se do paradigma de $\mathrm{CH}$ e assume tanto outra função quanto outra intenção. Sendo constantes os movimentos aparentemente associados ao ideário da representação coletiva de Camões na mente

\footnotetext{
${ }^{81}$ Imitação de um acontecimento em palavras, contando a história e não apresentando as personagens atuantes. (PAVIS, 2008, p. 96).

${ }^{82}$ Segundo Aristóteles, mimese é a imitação da ação (práxis). (PAVIS, 2008, p. 241).
} 
lusitana, a fusão entre História e Literatura visa a aproximar, ou melhor, cativar o espectador, deixando-o confortável. No entanto, é constantemente reiterado, por meio de recursos, normalmente épicos, paródicos ou estilizatórios, o distanciamento entre público e CHF.

Citam-se alguns exemplos do efeito de estranhamento no texto teatral com finalidade de manutenção da releitura crítica quando regateiras são postas em meio a um bordel, como integrantes de um coro, que se revela claramente paródico ao modelo aristotélico. Outro exemplo de estranhamento está na supressão de episódios recorrentes que se atribuem à vida de Camões, principalmente no que diz respeito à sua prisão e suposta prestação de serviços aos nobres.

Finalmente, o elemento que mais se destaca como estando a serviço desta criticidade é a viabilidade de $\mathrm{CH}$ ter efetivamente tomado parte nas expedições ultramarinas, o que caracteriza claro anacronismo histórico, porém atribui ao texto teatral o caráter de verossimilhança, posto que a epopeia camoniana, que jaz fixamente no ideário português, encontra aí um mote, ou seja, Os Lusíadas seriam o relato poético de um autor que "viveu" aquilo que escreveu. Neste sentido, o Camões ficcionalizado por Helder Costa, ou CHF, deixa de ser "fingidor", pois, de fato, segundo propõe o texto teatral, é um soldado prático, ou melhor, um soldado prático que se tornou poeta prático.

Assim como CHF experienciou as expedições ultramarinas na peça, Helder Costa foi testemunha ocular da ditadura salazarista. De certa forma, o dramaturgo constatou que o lusitano está preso a lembranças de tempos longínquos, tido como perfeitos.

A estagnação que advém do fato de apegar-se com tamanho ardor ao passado relaciona-se à mitologia de que o povo português é, de algum modo, "o escolhido". Desde a batalha de Ourique, quando D. Afonso Henriques teria supostamente sido comunicado por uma divindade de que os portugueses venceriam a batalha, a noção de que um poder maior rege o destino português ganhou força nos momentos de crise, tal como ocorreu com o Sebastianismo e, até mesmo, com a figura de Salazar, que, embora ditador, era considerado por muitos como a melhor alternativa para o comando do país. 


\section{CONSIDERAÇÕES FINAIS} A metaficção historiográfica vai realizar o preenchimento das lacunas deixadas pelos
vestígios de que trata Duby, implicando necessariamente uma visão ideológica do sujeito que escreve acerca do passado.

CORRADIN, 2013

Helder Costa tende a considerar o lusitano da atualidade um espectador, estagnado num passado de glórias, que não mais representa o Portugal de hoje. Essa dissertação buscou traçar um percurso analítico de A Viagem - Camões - Poeta prático, que levou em conta tanto o próprio texto teatral, quanto a proposta de seu dramaturgo, que consiste em reler criticamente o passado lusitano.

Perpassou-se pela História do Teatro, visando à compreensão de como o teatro épico, modelo de Helder Costa em sua composição teatral, se desenvolveu ao longo do tempo. Apresentou-se a História de Portugal, com a finalidade de munir-se de conhecimento a respeito do assunto, objetivando compreender a intertextualidade traçada pelo viés histórico.

Debruçou-se sobre o teatro brechtiano, a fim de diferenciá-lo e, inevitavelmente, aproximálo da concepção teatral de Helder Costa, que consiste, segundo as palavras do autor, em: “criar os temas e conseguir desmontar as vigarices, as mentiras que tinham sido ditas durante dezenas de anos. $^{83 \%}$. O autor também afirma que seu teatro não é anedota ordinária, mas “(...) precisamente através do espetáculo, além da pessoa se divertir, rir e se emocionar, ficar com mais alguma coisa na cabeça para pensar e para evoluir, para ser melhor cidadão no seu ambiente, e não só espectador de teatro. ${ }^{84,}$.

O dramaturgo não parece querer desmerecer o passado tido como áureo de Portugal, porém rejeita permanecer imóvel no tempo. Segundo a proposta de seu texto teatral, há que se recriar uma identidade lusitana que remeta ao presente, não se esquecendo do passado, que observe e não contemple, que reflita e não assista, maravilhado, mais pelo fato de não querer refletir acerca da atualidade do que pela suposta "verdade" que há na epopeia camoniana. Esta é, por excelência, a eternização de um tempo mítico, no qual a identidade portuguesa está profundamente enraizada, colocando-se "às margens do mundo", permanecendo, cada vez mais, distante tanto do passado quanto do presente.

\footnotetext{
${ }^{83}$ Entrevista de Helder Costa. Disponível em: http://www.livrariacamoes.ch/documentos/revistas/pdf_k_pessoas_469ceb1a138b5.pdf. Acesso em: 10 jan. 2015.

${ }^{84}$ Id. ibid.
} 
Portugal está visceralmente mergulhado em si mesmo, de onde se infere sua incapacidade de erguer-se, tanto em sentido literal, enquanto progresso, quanto em sentido abstrato, assemelhandose, de certo modo, a um gigante adormecido por sua derrocada, que se iniciou no final do período manuelino e, ao que parece, ainda não encontrou seu termo.

A questão identitária lusitana é brilhantemente compreendida pelo filósofo e ensaísta Eduardo Lourenço, em Mitologia da Saudade, quando afirma:

A cultura portuguesa não produziu nunca - pelo menos até Eça de Queirós - nem Montaigne, nem Montesquieu, nem Swift, nem Lessing, quer dizer, um olhar exterior a si mesma que a acordasse, não de qualquer cegueira dogmática ou culposa, mas da contemplação feliz e maravilhada de si mesma. Todos os povos vivem, mais ou menos, confinados no amor de si mesmos. Mas a maneira como os portugueses se comprazem nesta adoração é verdadeiramente singular. Seria absurdo pretender que um povo entre outros e, ainda por cima, um pequeno povo, possa estar fora ou escapar a este maelström ${ }^{85}$ a que chamamos História. Contudo, evitar o destino comum, instalar-se, não se sabe por que aberração ou milagre, às margens do mundo, foi um pouco aquilo que o povo português sempre tem feito. Portugal vive-se "por dentro" numa espécie de isolamento sublimado, e "por fora" como o exemplo dos povos de vocação universal, indo a ponto de dispersar o seu corpo e a sua alma pelo mundo inteiro. A imagem é de Camões, e todos os portugueses a conhecem de cor. Essa mitologia está inscrita na bandeira portuguesa. Portugal é o único país que colocou no centro da sua bandeira a esfera armilar, a representação do universo. (LOURENÇO, 1999, p. 9-10).

Esta contemplação "feliz e maravilhada" inclui em seu bojo uma certa ausência de autorreflexão, na medida em que o português de hoje tende a enxergar-se, ainda, como seus antepassados, da época das expedições ultramarinas. Alguns elementos contribuem significativamente para que Portugal se ensimesme. Fatores que antigamente lhe propiciaram a primazia ultramarina hoje rendem-lhe o aprisionamento: país pequeno, circundado por mar, fronteiriço com a eterna rival Espanha, imbuído de um profundo catolicismo, perdido nas glórias dos tempos de outrora.

O povo português, altamente nostálgico e saudosista, insiste em não se desprender de seu passado, oscilando entre os sonhos de grandeza de outros tempos e a dura realidade atual. Segundo o ditado: "Quem foi rei nunca perde a majestade.". No caso português, houve a perda do status de Império, porém não o desapego do que foi perenizado n'Os Lusíadas, sentimento cristalizado por uma palavra genuinamente portuguesa: saudade.

${ }^{85}$ Grande turbilhão de águas. 
Portugal não regressou ao lar; perdeu ou abandonou sua identidade num desses mares do novo mundo e criou-se o mito de viver no presente, mas "achar-se" no passado. Nesse sentido, ainda de acordo com Eduardo Lourenço:

(...) d. Francisco Manuel de Mello supôs, primeiro do que ninguém, que Portugal se tornara este povo de uma nostalgia sem verdadeiro objeto devido ao seu destino de povo marítimo, viajante, separado de si mesmo pelas águas do mar e do tempo. Sem dúvida que o nosso destino de errância conferiu a esta nostalgia, a esse afastamento doloroso de nós mesmos, o seu peso de tristeza e de amargura, a sua coroa de bruma. É a lembrança da casa abandonada, esse gosto de mel e de lágrimas, que a palavra mito dos portugueses sugere. $(1999$, p. 12).

Enquanto Eduardo Lourenço parece ver com clareza que essa nostalgia que tanto caracteriza o povo português é geradora de um "afastamento doloroso de nós mesmos", de onde advém "o seu peso de tristeza e de amargura", os poetas Luís de Camões e Fernando Pessoa parecem pactuar de um ponto de vista distinto. O primeiro povoa, por meio de sua epopeia, o imaginário do que foram as expedições ultramarinas, embora admita-se que, excetuando os raros momentos de oposição às práticas expansionistas, tais como o episódio do Velho do Restelo e o epílogo, em que o vate afirma: "Cantar a gente surda e endurecida", o teor laudatório preenche quase que por completo o poema épico. O segundo, no poema Mar Português, embora reconheça as duras perdas, as mortes e as desgraças, atribui validade aos feitos ultramarinos, posto que o português tem a alma grande, tais como foram seus sonhos durante os séculos XV e XVI.

Helder Costa, por sua vez, compreende que a postura apática, idealista ou mesmo indiferente não é capaz de alterar o hoje. Assim, diante disso, assume-se como integrante dessa Nação, em que o sol chegou a nunca se pôr, com a "missão" quase que patriótica de abrir os olhos, libertar a mente e, principalmente, oferecer ao público português uma viagem na qual se embarca carregado do ideário saudosista, mas retorna-se prático, ou seja, consciente de que a História e o Presente são as possibilidades de intervenção do homem em qualquer sociedade. No entanto, é preciso abandonar o conforto dos antigos pressupostos e dispor-se a reinventar-se, assim como o protagonista do texto teatral em questão, que faz, experiencia, ama a Pátria, porém não esconde das vistas seus reveses, em uma prova que legitimamente configura-se como um ato de amor autêntico e nacionalista à ilustre Pátria Lusitana. 


\section{REFERÊNCIAS}

ALBUQUERQUE, Luís de; MAGALHÃES, Ana Maria; ALÇADA, Isabel. Os descobrimentos portugueses: viagens e aventuras. Lisboa: Editorial Caminho, 1991.

ANSELMO, Arthur. Camões e a Censura Literária Inquisitorial. Braga: Barbosa \& Xavier, 1982.

ARISTÓTELES; HORÁCIO; LONGINO. A Poética Clássica. São Paulo: Cultrix/Edusp, 1981.

ARNOLD, David. A Época dos Descobrimentos: 1400-1600. Lisboa: Codex, 1983.

BAKHTIN, Mikhail. Problemas da poética de Dostoiévski. Trad. direto do russo, notas e prefácio: Paulo Bezerra. 5. ed. revista. Rio de Janeiro: Forense Universitária, 2010.

BALL, David. Para trás e para frente: um guia para leitura de peças teatrais. 2. ed. Trad. Leila Coury. São Paulo: Perspectiva, 2014. Coleção Debates; 278, dirigida por J. Guinsburg.

BARROS, Diana Luz Pessoa de. Teoria do discurso: fundamentos semióticos. 3. ed. São Paulo: Humanitas, 2001.

Diana Luz Pessoa de; FIORIN, José Luiz (org.). Dialogismo, polifonia, intertextualidade: em torno de Bakhtin. 2. ed. São Paulo: Editora da Universidade de São Paulo, 2011.

BELLO, João Alfredo Dal. Drama histórico: leitura metateatral de Brecht e Dorst. São Paulo, 1997. Tese (Doutorado em Literatura Alemã) - Faculdade de Filosofia, Letras e Ciências Humanas, Universidade de São Paulo.

BERTHOLD, Margot. História Mundial do teatro. Trad. Maria Paula V. Zurawski; J. Guinsburg; Sérgio Coelho; Clóvis Garcia. São Paulo: Perspectiva, 2010.

BORNHEIM, Albert Gerd. Brecht: a estética do teatro. Rio de Janeiro: Graal, 1992.

BOSI, Alfredo. Reflexões sobre arte. 2. ed. São Paulo: Série Fundamentos, 1986.

BRAIT, Beth. Ironia em perspectiva polifônica. Campinas: Unicamp, 1996.

BRECHT, Bertold. Poemas 1913-1956. 5. ed. São Paulo: Editora 34, 2000.

CAMÕES, Luís Vaz de. El-Rei Seleuco. Prefácio e notas de Vieira de Almeida. Lisboa: Revista Ocidente, 1944.

. Lírica. Seleção, prefácio e notas de Massaud Moisés. São Paulo: Editora Cultrix, 1976. . Os Lusíadas. São Paulo: Abril, 1979.

1993. . Os Lusíadas. Introdução e notas por Alexei Bueno. Rio de Janeiro: Editora Nova Fronteira, 
CÂNDIDO, Antonio et alii. A personagem de ficção. São Paulo: Perspectiva, 2009. Coleção debates; 1, dirigida por J. Guinsburg.

CARVALHO, Joaquim Barradas de. O Renascimento Português: em busca da sua especificidade. Lisboa: Imprensa Nacional - Casa da moeda, 1980.

CASSIRER, Ernst. Linguagem e Mito. Trad. J. Guinsburg; Miram Schnaiderman. São Paulo: Perspectiva, 2009. Coleção Debates; 50, dirigida por J. Guinsburg.

CHEVALIER, Jean; GHEERBRANT, Alain. Dicionário de símbolos: mitos, sonhos, costumes, gestos, formas, figuras, cores, números. 2. ed. Rio de Janeiro: José Olympio Editora, 1990.

CIDADE, Hernani. Luís de Camões: O Teatro e as Cartas, Artis, Lisboa, 1962.

. Luís de Camões: a obra e o homem. 4. ed. Lisboa: Arcádia Editora, 1980.

- Lições de cultura e literatura portuguesas. 7. ed. corrigida e actualizada. Coimbra: Coimbra Editora, 1984. v.1- século XV, XVI e XVIII.

CIRLOT, Juan-Eduardo. Dicionário de Símbolos. Trad. Rubens Eduardo Ferreira Frias. 2 ed. São Paulo: Ed. Moraes, 1984.

COELHO, António Borges. Questionar a história: ensaios sobre a história de Portugal. 2. ed. Lisboa: Editorial Caminho, 1983.

CORRADIN, Flavia Maria. Antônio José da Silva, O Judeu: Textos versus (con)textos. Cotia: Íbis, 1998.

. O teatro da história em Jaime Gralheiro: futuro de que passado? São Paulo, 2013. 237f. Tese (Livre Docência) - Faculdade de Filosofia, Letras e Ciências Humanas, Universidade de São Paulo.

COSTA, Helder. A Viagem - Camões - Poeta prático. Coimbra: Centelha, 1982.

Fernão, mentes? - versão livre da 'Peregrinação', de Fernão Mendes Pinto. Textos A Barraca. Lisboa, 1982.

. COSTA, Helder. In: Dramaturgia de Abril. Lisboa: Sociedade Portuguesa de Autores. Publicações Dom Quixote, 1994.

COTRIM, Gilberto. História e Consciência do Mundo. 4 ed. São Paulo: Saraiva, 1996.

COUTO, Diogo do. O Soldado Prático. Texto restituído, prefácio e notas pelo professor M. Rodrigues Lapa. Lisboa: Editora Lisboa, 1937. Coleção de clássicos Sá da Costa.

DUBY, Georges; ARIÈS, Philippe; LE GOFF, Jaques; LADURIE, Le Roy. História e nova história. Trad. Carlos da Veiga Ferreira. 2. ed. Lisboa: Editora Safil Lda., 1989.

ELIADE, Mircea. Mito e realidade. Trad. Pola Civelli. São Paulo: Perspectiva, 2007. Coleção Debates; 52, dirigida por J. Guinsburg. 
FILHO, Aderbal Freire. Estudos sobre teatro: Bertold Brecht. 2. ed. Trad. Fiama Pais Brandão. Rio de Janeiro: Nova Fronteira, 2005.

FISCHER, Ernst. A necessidade da arte. 5. ed. Trad. Leandro Konder. Rio de Janeiro: Zahar Editores, 1976.

HUGHES, H. STUART. La historia como arte y como ciencia. Trad. Matilde Vilarroig. Madrid: Editora Aguilar, 1967.

JENKINS, Keith. A História repensada. Trad. Mario Vilela. 2. ed. São Paulo: Editora Contexto, 2004.

KOUDELA, Ingrid Dormien. Um vôo brechtiano: teoria e prática da peça didática. São Paulo: Perspectiva: Fapesp, 1992. Coleção debates; 248, dirigida por J. Guinsburg.

. Brecht: um jogo de aprendizagem. São Paulo: Perspectiva, 2007. Coleção estudos; 117 , dirigida por J. Guinsburg.

KRISTEVA, Julia. História da linguagem. Trad. Maria Margarida Barahona. Lisboa: Edições 70, 1969.

LAPA, Rodrigues [seleção, prefácio e notas]. Historiadores Quinhentistas. 3. ed. Editora Seara Nova, 1972. Coleção: Textos literários.

LE GOFF, Jacques; NORA, Pierre. História: Novos Objetos. Trad. Terezinha Marinho. Rio de Janeiro: Francisco Alves, 1995.

LOURENÇO, Eduardo. O Labirinto da Saudade. 3. ed. Lisboa, Publicações Dom Quixote, 1988.

Letras, 1999.

Mitologia da saudade: seguido de Portugal como destino. São Paulo: Companhia das . A nau de Ícaro: seguido de Imagem e Miragem da lusofonia. 3. ed. Lisboa: Gradiva, 2004.

LYOTARD, François. A condição pós-moderna. Lisboa: Gradiva, 1989.

MACHADO, Alleid Ribeiro. O plantador de naus a haver sob a óptica da intertextualidade. São Paulo - 2006. Dissertação (Mestrado em Literatura Portuguesa) - Faculdade de Filosofia, Letras e Ciências Humanas, Universidade de São Paulo.

MAGALDI, Sábato. O texto no teatro. 3. ed. São Paulo: Perspectiva, 2012. Coleção Estudos; 111.

MARINHO, Maria de Fátima. O romance histórico em Portugal. Porto: Campo das Letras, 1999.

MARQUES, A. H. Oliveira de. História de Portugal: Desde os tempos mais antigos até à Presidência do Sr. General Eanes. 4. ed. Lisboa: Palas Editores, 1974.

. História de Portugal: Desde os tempos mais antigos até à presidência do Sr. General Eanes. 9. ed. Lisboa: Palas editores, 1978. v.1 - desde os tempos mais antigos até ao governo do Sr. Pinheiro de Azevedo. 
. História de Portugal: Desde os tempos mais antigos até à presidência do Sr. General Eanes. 9. ed. Lisboa: Palas editores, 1983. v.2 - desde os tempos mais antigos até à presidência do Sr. General Eanes.

. História de Portugal: Desde os tempos mais antigos até à presidência do Sr. General Eanes. 12. ed., Lisboa: Palas editores, 1985. v.1 - das origens ao renascimento.

MATTOSO, José (dir.). História de Portugal. v. 3 - no alvorecer da modernidade (1480-1620). Lisboa: Editorial Estampa, 1993.

MOISÉS, Massaud. Dicionário de termos literários. 12. ed. rev. e ampl. São Paulo: Cultrix, 2004.

NUÑEZ, Carlinda Fragale Patê. O teatro grego. In: $O$ teatro através da história. Rio de Janeiro: Entourage Produções Artísticas, 1994, p. 17-30.

OLSHEWSKY, Thomas M. The Classical Roots of Hume's Skepticism. In: Journal of the History of Ideas, v.52, n 2 (abril - junho, 1991), p. 269-287.

PALlOTTINI, Renata. Dramaturgia: Construção do personagem. São Paulo: Ática, 1989. Série Fundamentos 46. . Introdução à Dramaturgia. São Paulo: Ática, 1988. Série Princípios.

PASTA, José Antonio. Trabalho de Brecht: breve introdução ao estudo de uma classicidade contemporânea. São Paulo: Editora 34, 2010.

PAVIS, Patrice. Dicionário de teatro. 3. ed. São Paulo: Perspectiva, 2008.

PEIXOTO, Fernando. O que é teatro. São Paulo: Brasiliense, 2012.

PORTUGAL. Instituto de Cultura e Língua Portuguesa - Ministério da Educação e Ciência. Camões no Portugal de Quinhentos. Portugal, 1981. v.60 da coleção Biblioteca Breve.

REBELLO, Luiz Francisco. O Primitivo Teatro Português. Lisboa: Instituto de Cultura Portuguesa, 1977.

RIBEIRO, Eduardo. Camões em Macau: uma certeza histórica. Macau: Edição COD, 2007.

ROSENFELD, Anatol. O Teatro Épico. 4. ed. $2^{\mathrm{a}}$ reimpressão. São Paulo: Perspectiva, 2006. Coleção debates; 193, dirigida por J. Guinsburg.

SANT'ANNA, Affonso Romano de. Paródia, Paráfrase \& Cia. São Paulo: Ática, 1991.

SARAIVA, António José. Luís de Camões: estudo e antologia. 2. ed. rev. Publicações EuropaAmérica, 1972. Coleção: Obras de António José Saraiva.

Para a história da cultura em Portugal. 3. ed. Publicações Europa-América, 1972. v.II. Coleção: Obras de António José Saraiva.

; LOPES, Oscar. História da Literatura Portuguesa. 17. ed. corrigida e atualizada. Porto: Porto Editora, 2010. 
SARAIVA, José Hermano. Vida ignorada de Camões. 2. ed. rev. e acresc. Publicações EuropaAmérica, 1978.

. História de Portugal. Lisboa, Publicações Alfa, 1983. v. 3.

. (org.) História de Portugal. 4 ed. Lisboa, Publicações Alfa, 1993. v. 3.

. História Concisa de Portugal. 18. ed. Portugal: Publicações Europa-América lda., 1996.

SENA, Jorge de. Ressonâncias e cinquenta poemas. Rio de Janeiro: 7 Letras, 2006.

SERRÃO, Joaquim Veríssimo. História de Portugal: a formação do Estado moderno (1415 1495). 8. ed. Lisboa: Editorial Verbo, 1996. v.2.

SILVA, Haidê. A metaficção historiográfica no romance: Os cus de Judas, de Antonio Lobo Antunes. São Paulo, 2007. Dissertação (Mestrado em Literatura Portuguesa) - Faculdade de Filosofia, Letras e Ciências Humanas, Universidade de São Paulo.

SILVA, Luiz Geraldo. A faina, a festa e o rito: uma etnografia histórica sobre as gentes do mar (sécs. XVII ao XIX). Campinas: Papirus, 2001.

SILVA, Rogério Forastieri da. Historiografia e Nova História. São Paulo, 1999. 413f. Tese (Doutorado em História) - Faculdade de Filosofia, Letras e Ciências Humanas, Universidade de São Paulo.

SILVA, Vítor Manuel de Aguiar e. Para uma interpretação do Classicismo. In: Revista de História Literária de Portugal, Coimbra: Faculdade de Letras, 1962. v. I, p. 1-64.

. Teoria da Literatura. 3. ed. rev. e aum. Coimbra: Livraria Almedina, 1973.

. Camões: labirintos e fascínios. Lisboa: Editora Cotovia, 1994.

SILVEIRA, Francisco Maciel. A edição de Os Lusíadas, segundo o olhar (Aquilino) de Saramago. In: LOPONDO, Lilian (org.). Saramago segundo terceiros. São Paulo: Humanitas, 1998.

Perspectiva.

Poesia Clássica: literatura portuguesa. São Paulo: Global, 1988. Série: Literatura em

SPANG, Kurt. El drama historico: teoria y comentarios. Navarra: Ediciones Universidad de Navarra, 1998.

WHITE, Hayden. Trópicos do discurso: ensaios sobre a crítica da cultura. Trad. Alípio Correia de Franca Neto. São Paulo: Editora da Universidade de São Paulo, 1994. Ensaios de Cultura; v.6.

\section{SITES}

http://www.abarraca.com/. Acesso em: 9 jun. 2012.

www.espacoportugues.ch/pessoas_26.pdf. Acesso em: 13 jul. 2012.

https://www.bibliaonline.com.br/acf/lc/23 Acesso em: 26 mar. 2014.

http://repositorio-aberto.up.pt/bitstream/10216/55944/2/tesemestnellysilva000127745.pdf.

Acesso em: 14 abr. 2014. 
Www.ordens.presidencia.pt/?idc=179. Acesso em: 10 jan. 2015.

http://www.abarraca.com/index.php?option=com_barraca\&view=ecos\&Itemid=7. Acesso em: 10 jan. 2015.

www.arqnet.pt/portal/portugal/temashistoria/index.html. Acesso em: 25 jan. 2015. 


\section{APÊNDICE}

Entrevista de Helder Costa para o banco de dados do Projeto Autor por Autor: A Literatura e História Portuguesas à luz do teatro (realizada em 1/08/2011)

Parte I

Projeto "Autor por Autor: A Literatura e a História Portuguesas à luz do teatro"

Profs. Drs. Flavia Maria Corradin e Francisco Maciel Silveira, da Faculdade de Filosofia, Letras e Ciências Humanas, da Universidade de São Paulo.

\section{Informações Biobibliográficas}

Helder Costa

A) Nascimento (data, local, filiação)

Grandola, Portugal, 6 de Janeiro de 1939.

Filho de José Pereira da Costa e Maria José Mateus da Costa

B) Formação/Atividade

Estudos de Direito em Coimbra e Lisboa

Institut D'Etudes Théâtrales - Sorbonne, Paris - França

Escritor, Dramaturgo, Encenador, Professor, Actor

C) A viagem - Camões - Poeta prático (Primeira encenação: data, local e Cia. Teatral)

Lisboa, 13 de Fevereiro de 1982, Teatro A Comuna, encenação João Mota

D) Qual (quais) julga ser(em) a(s) força(s)-motriz(es) de sua obra?

Penso que é a sequência do itinerário criativo e humano de Camões, integrado no seu tempo, saudavelmente boémio, satírico, corajoso, marginalizado e com um final triste, miserável e abandonado. $O$ retrato do tempo e de um país que iria perder a independência. 
E) Como se dá seu processo de criação?

Documento-me sobre os personagens, os factos e o entorno político e social. Para isso, nunca deixo de ler autores com opiniões contrárias às minhas. Não há como ler o "inimigo" para chegar às verdades Históricas.

E depois... asas à imaginação. Sem preconceitos, libertária e com o gosto do risco.

II. Entrevista (perguntas elaboradas pelos professores Francisco Maciel Silveira e Flavia Corradin, coordenadores do projeto a que minha pesquisa está submetida)

1) Concorda com o diagnóstico de Eça de Queiroz, em páginas de Uma campanha alegre, que "o português não tem gênio dramático; nunca o teve, mesmo entre as passadas gerações literárias, hoje clássicas. A nossa literatura de teatro toda se reduz ao Frei Luís de Sousa"?

Acho que o Eça caiu no vício do pessimismo elitista francófono.

Temos de pensar que seria normal haver herdeiros de Gil Vicente e Chiado, glórias dramatúrgicas do século XVI.

Mas aconteceu que a Inquisição começou em 1536 e terminou em 1820! Não é legítimo julgar que houve perseguições, proibições e destruição de inúmeros textos?

Aliás, o mesmo se passou no século XX. Depois da República de 1910, perseguida, invadida, ultrajada e manchada de crimes e assassinatos, soçobrou ao golpe militar de 1926. Que se seguiu? Ditadura fascista que só terminou em 1974!

Daí que tenha sido difícil criar textos dramáticos porque só se completam quando se apresentam no palco perante o público. A Censura proibia, evidentemente.

E deve ser por isso que se diz que Portugal foi sempre um país de poetas. Compreende-se. É uma arte intimista, pode-se escrever, guardar na gaveta, ou sussurrar em tertúlias de amigos.

2) A narrativa-dramática, posta em voga por Cardoso Pires com $\mathbf{O}$ render dos heróis e levada às últimas consequências pelo ciclo épico-social de Bernardo Santareno, teria, através da simples leitura, a mesma eficácia interveniente do discurso veiculado no palco?

O teatro é um ramo da Literatura que só existe no palco. Por mais belo, bem carpinteirado que seja o texto, ele só existe quando é representado. 
3) Em sua opinião, o que levaria um Autor a manter diálogo intertextual com a obra de outrem? No seu caso, mais especificamente, o que o motivou a escrever A viagem - Camões - Poeta prático?

Sendo Camões um ícone de Portugal, e tendo uma vida que foi um exemplo cristalino da “responsabilidade intelectual”, pelo estudo, pela coragem polémica, por saber sujar as mãos em rudes e baixas tarefas, era um tema que interessava apresentar no Portugal da recente Revolução de Abril.

Estávamos a começar a aprender o que era a Liberdade, alimpar as teias de aranha reaccionárias que nos enredavam. Era necessário dar bons exemplos da nossa sofrida História.

4) Como explica a tendência de a dramaturgia portuguesa vir desde o Romantismo repensando a História, dramatizando vida e obra de autores, figuras ou lances fundamentais do passado? Por acaso essa releitura do passado em busca de uma identidade nacional seria, como diz Eduardo Lourenço em Labirinto da Saudade, a propósito de Frei Luís de Sousa, "a teatralização de um Portugal como povo que só já tem ser imaginário"?

Há várias formas de reler o passado. Na Monarquia Constitucional, campanha Republicana apoiava-se em figuras do passado para tirar o país da tal "apagada e vil tristeza". O tempo de Salazar usou o passado para justificar nacionalismos, colonialismos e falsa grandeza Imperialista.

Com o 25 de Abril, começou-se a tentar perceber o passado de forma como pede o realismo científico: dialéctico e anti-maniqueísta.

A frase de Eduardo Loureço, nos dias de hoje, devido ao Imperialismo Norte-Americano a que chamam eufemisticamente de Globalização, é infelizmente adaptável a qualquer país. E é por isso que se verifica um Renascimento de valores locais e de tradições - vestuário, culinária, brinquedos, etc. - que até podem conduzir a perigosos ressurgimentos nazis, como se verifica por toda a Europa.

5) Sem dúvida o drama histórico (de matiz romântico e patrioteiro) se diferencia daquilo que, se não me engano, José Oliveira Barata chama de teatro da História (de matriz piscatoriana e brechtiana). No caso do teatro da História, o distanciamento, o estranhamento pretérito, serve para revelar as mazelas do presente. Ou seja, perspectiva-se o passado como história do presente. Uma tal óptica - creio - implica que o espectador ou o leitor esteja devidamente informado acerca do fato pretérito, que está sendo tratado como alegoria ou símbolo do presente, para que possa fazer as 
ilações e paralelismos devidos. No caso de o público não ter tais informações históricas, como estrategicamente se lhe desperta essa consciência? Através do didatismo de um narradorcomentador? O didatismo do narrador-comentador à Brecht não pode prejudicar a ação, o conflito, mola-mestre de um texto dramático? Proponho-lhe tais questões pensando em A viagem - Camões Poeta prático?

É evidente que me desagrada o recurso ao narrador-comentador, e nunca o utilizei.

Escrevi muitos textos sobre acontecimentos que não são conhecidos pelo grande público e nem por alguns Académicos.

Tento resolver esse problema através de textos que permitem por "simpatia" identificálos com os procedimentos e pensamentos actuais. Porque, na prática, a vida do Homem é Universal e intemporal.

III. Espaço reservado para qualquer outra manifestação do autor

Espero que o teatro saia da sua "eterna crise". Para isso, que assuma a responsabilidade de cidadania, de ser subvertor, de acordar o marasmo cívico das sociedades actuais.

Que saiba aproveitar este tempo sem Censuras oficiais. (Claro que há as outras, mas isso é outra luta). Que se responsabilize por espalhar beleza, alegria e conhecimento.

Que perceba que uma sociedade desanimada nunca será capaz de lutar, de progredir e ser independente. E que nunca se esqueça de utilizar a fantástica arma do HUMOR, verdadeiro susto e horror destes fantoches de pacotilha que enxameiam a Economia e a Mídia.

Prezado Helder Costa, agradecemos antecipadamente sua colaboração, deixando-lhe a certeza de que está contribuindo para o sucesso de um projeto que, como já lhe disse, visa ao estudo e à divulgação da dramaturgia portuguesa contemporânea, carente no Brasil de informações biobliográficas de seus principais representantes. 
Parte II

I. Perguntas referentes à obra do autor, elaboradas por Caroline de Almeida Nascimento.

1) Por que você optou por trabalhar com a modalidade histórica da intertextualidade?

Portugal tinha saído de $\mathbf{5 0}$ anos de ditadura fascista. Claro que era necessário rever a nossa História e a nossa Cultura para corrigir as manipulações e as falsidades mascaradas de "nacionalismo".

2) Em sua opinião, qual é a função da arte? E do teatro? Com quem o teatro dialoga na sociedade contemporânea?

A função da Arte é múltipla e, por vezes, contraditória. Para mim, não consigo dissociá-la da beleza, da inteligência e do impacto social (claro que tenho a humildade de reconhecer que tudo isto é subjectivo).

Quanto ao teatro, que eu considero uma forma de Arte e um meio de comunicação, tem mais responsabilidade cívica e política. E é por isso que está sempre a ser censurado pelas ditaduras e a ser utilizado pelas oposições moderadas ou revolucionárias. Eu penso que o teatro tem de saber dialogar com todas as classes e com todos os temas. Digamos que eu só exijo ao meu trabalho que ele seja atractivo, não gratuito, e de grande clareza temática.

3) Em que medida o gênero histórico/poético pode ser trazido aos palcos? Quais são os maiores desafios e as maiores conquistas desta opção de representação?

Esse género não pode transportar cargas poeirentas e ultrapassadas.

Homenagear os clássicos é modernizá-los e torná-los acessíveis ao público dos nossos dias. É nessa dificuldade que consiste o prazer de conseguir demonstrar que as histórias antigas têm a ver com o sempre constante e irregular comportamento humano.

4) Como se deu a escolha do título da peça A viagem - Camões - Poeta prático? Fale sobre seu significado.

O primeiro título foi “Camões, poeta prático" a que depois acrescentei "A viagem", devido à encenação de João Mota no grupo "Comuna". 
Poeta prático porque todo o seu saber, além do estudo, se baseia na experiência vivida, no amor, na guerra, nas perseguições, na miséria e no abandono da sua morte.

5) O que motivou a escolha de Camões como personagem principal da peça? Em sua opinião, que contribuições ele poderia dar à modernidade?

Camões é um dos símbolos mais importantes do nosso século de oiro, o século XVI. E é um testemunho vivo do intelectual moderno e progressista na linha de Erasmo e Tomas More, seus contemporâneos. Através dos séculos, foi sempre referido como um patriota pelos liberais e Republicanos e também utilizado pelas famílias mais reacionárias (descendentes dos mesmos que sempre o perseguiram e lhe negaram qualquer apoio e protecção económica).

Por isso, era necessário fazer uma "operação de limpeza" ao nosso Camões e mostrá-lo em toda a sua grandeza e independência, para exemplo aos jovens e intelectuais dos nossos dias.

6) Qual foi sua intenção/sentimento ao propor no palco um novo olhar para o ícone Camões e para o período das grandes navegações portuguesas, tido como áureo para a nação lusitana?

Não é minha intenção negar esse período áureo, mas é preciso conhecer todas as realidades que eram sonegadas e ocultadas. Na linha de Gil Vicente, Fernão Mendes Pinto, Damião de Góis e Chiado, que denunciaram nessa mesma época que esse período áureo se devia ao trabalho de cientistas e ao povo que era arrastado para as naus. E que descobrimento foi frequentemente sinónimo de roubo e massacres. A História não se pode corrigir, mas eu só posso gostar do meu país (ou de qualquer outro) se conhecer os lados positivos e os condenáveis.

7) O que esta peça lhe acrescentou como teatrólogo? E como cidadão português?

Foi importante porque vinha na sequência de "Zé do Telhado" e "D. João VI", e me deu mais confiança para seguir nessa investigação que continuo até hoje. Como cidadão português, foi ter conseguido que se conhecesse melhor o "poeta da Pátria" também a nível internacional. 